
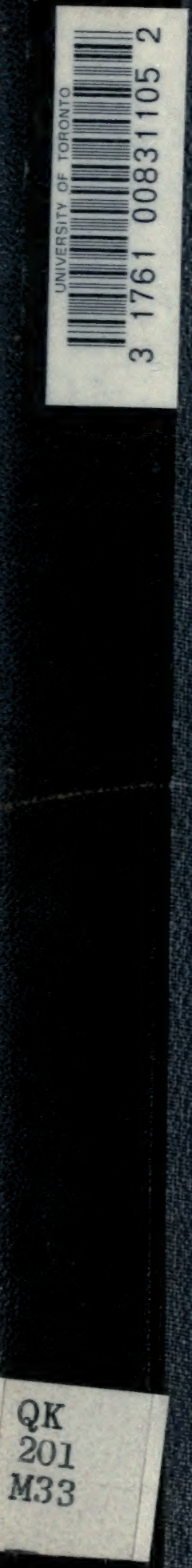


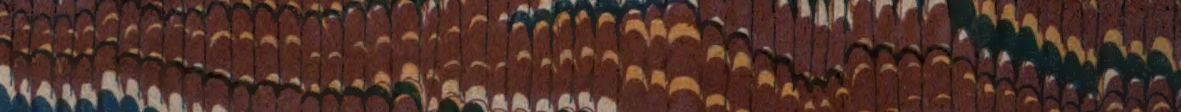

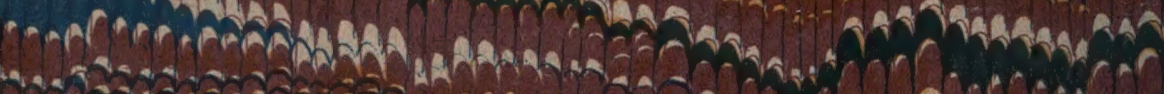

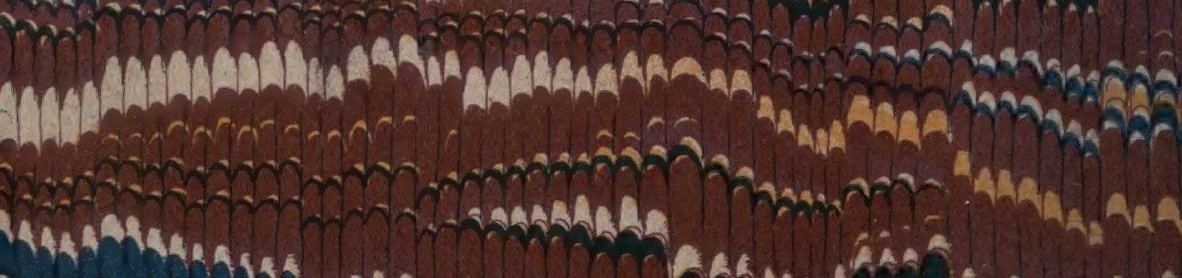

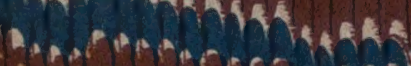

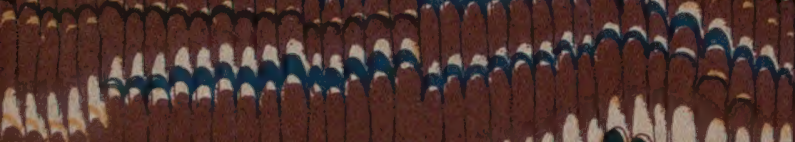

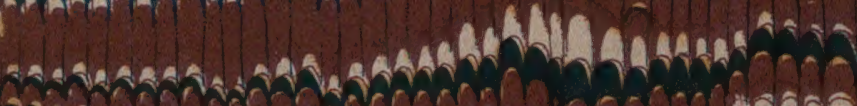

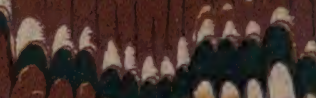

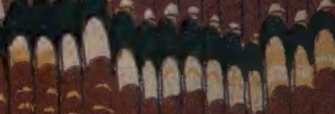
कW

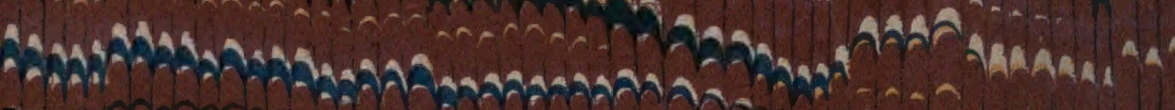
ถ้.

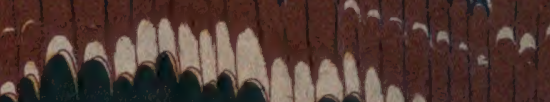

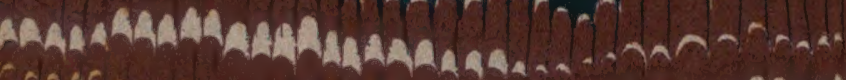

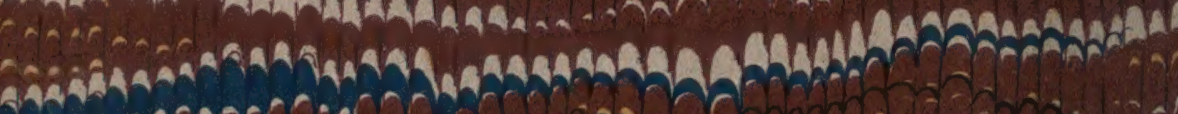
$\operatorname{lat}_{-1}$

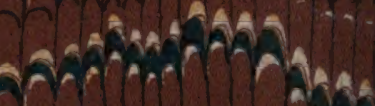

$\tan \theta$
2in:

A A AADARA.

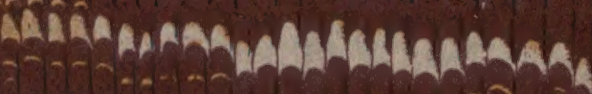

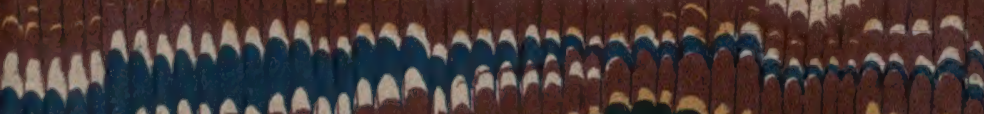
Aata $A$ A

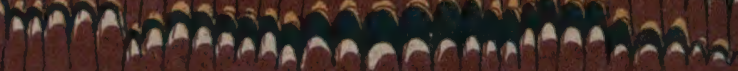

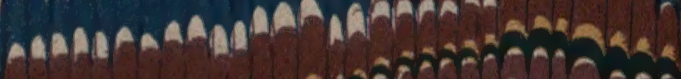

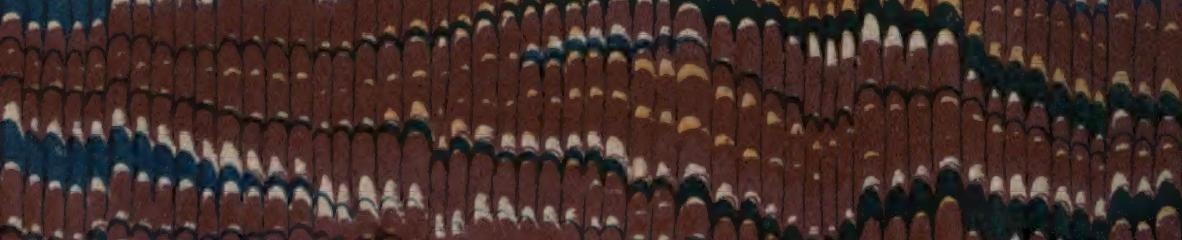




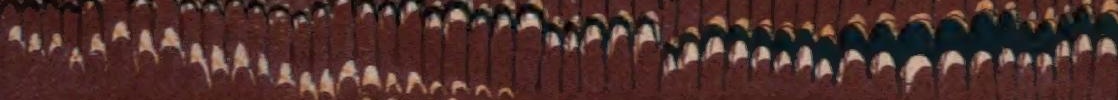

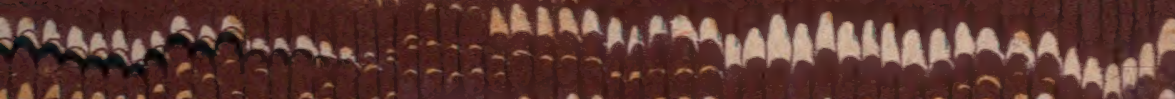
ansench

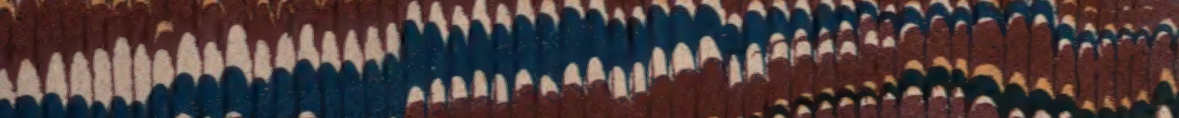
11. 

REPRINT

\section{MAR 171960}


Digitized by the Internet Archive in 2008 with funding from Microsoft Corporation 
$6^{0^{3}}$ 


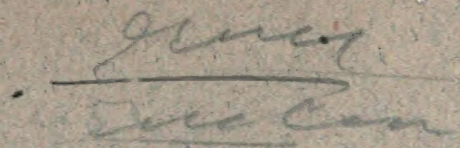

\section{$1894-1906$}

\section{Contributions from the Herbarium of the} Geological Survey of Canada.

(By Permission of the Director.)

By James M. Macoun.

Curator of the Herbarium.

I.

"Reprinted from the Canadian Record of Science, January, 1894." 

Contributions from the Herbarium of the Geological Survey of Canada.

(By Permission of the Director.)

-

By James M. Macoun,

Curator of the Herbreium.

I.

"Reprintul jrom the Canadian Record of Science, January, 1894."

\section{$=1373$}





\title{
Contributions to Canadian Botany.
}

\author{
By Jas. M. Macour.
}

I.

Since the publication in 1890 of Part Y. of Prof. John Macoun's Catalogue of Canadian Plants the geographical range of many species has been extended, many additional species have been added to the Flora of Canala and not a fow species and rarieties have been discorered that have proved new to science.

A record of these later discoreries has been kept by the writer and it is proposed in these papers to publish such notes as it is thuught will prore of greneral interest to botanists.

This plan will exclucle such facts as are of local interent only. That a plant common in rarious parts of (1ntario, for example, should hare been found in another part in which it was not known to grow, will not be considered of sufficient general interest to be recorded here but when the plant is quite new to the country, of extreme rarity, or of rery restricted distribution new stations for it will be considered worthy of record and when possible its hal,itat. mode of growth etc.. will also be given. 
Descriptions of new species will also be published, and where recent revisions of genera or orders have made note. worthy changes in the nomenclature of Canadian plants, corrections will be made in the work already done.

\section{Aconitum Columbianum, Nutt.}

This beautiful aconite was first collected in Canada by Mr. Jas. MeEvoy between Stump and Chaperon Lakes South of Kamloops, B. C. Mr. MeEvoy describes it as growing in rich soil in open spaces between thickets and as being frequently found three feet in height. It was afterwards noted by Mr. McEvoy in several localities between the Spullamacheen or Shuswap River and where it was first found by him.

Brasgenia peltata, Pursh.

Common in Eastern Canada; collected in Jangford Lake, Vatcouver Jsland and in 1893 in Stanley Park, Vancouver. B. C., not before recorded from Western Canada.

\section{Cardamine bellidifolia, Linn.}

Until 1890 this little cress had not been collected in C'anada since the time of Franklin's Fecond Journey when it was found in the Rocky Mountains by 1)rummond and the arctic regions by Dr. Richardson. In 1890 it was discovered by the writer on Avalanche Mt. near Roger's P'ass in the Selkirk Mountains, 13. ('., at 7,500 ft. altitude, But five sperimens in all were found, none of them exceeding an inch in height. They were growing in mud close to al rock over which water continually trickled. I few spocimens of this species were also found by P'rof'. Macoun on Mit. Aylmer, Devil's Lake, Rocky II ts. in 18!1, alt. $8000 \mathrm{ft}$.

LEPEDIUM OXYCARPUM, T. \& G.

Specimens of a reduced form of this plant were collected in 1893 by Pror. Macoun at ('alboro Bay near Victoria Van. Island. New to Canada. 


\section{Thysanocarpus pugillug, Hook.}

C'ommon in parts of Vaneourer Island but not found in Brit. Columbia until 1890 when it was collected at Sproat on the Columbia River by Prof. Macoun.

\section{Claytonia cordifolia, Wat.}

Found by Prof. Ifacoun at an attitude of $5000 \mathrm{ft}$. on the mountains near Warm springs, Kootanie Lake, B. C. New to Canada.

Eilatine Americana, Arn.

In his catalogue of Canadian Plants Prof. Macoun gires hut one station for this species--Long Lake in Assinaboia. During the past four years it hats been found in widly separated localities so that we may now safely way that though of local securrence it ranges in ('anatat fromi the Itlantic to the Pacific. New stations for this species are Tadousac Lake, (que. (Gंen. G. Kennedy.) Hull, (Que., and Alberni, Vaticourer Island. (John Macoun.) Port Sandtield, Muskoka, (Int. (Dr. and Mrs. Britton and Miss Timmerman.)

\section{Astragalug leegcopsis, Torr.}

One clump of this plant was found by Prof. Macoun near Yanaimo, Tan. Island in 1893. The seed wat doubtless brought from California in ballast.

\section{Ludigia alternifolia, L.}

Collected hy Mr. Alex. Wherry of Windsor, Ont. in 18.13. Mr. Wherry writes:- "It is found in low rich, swampy ground generally meadows and pastures, about 2 miles west of sandwich. Unt.; also within half mile of Windsor, Ont. Quite common in these places but nut met with elsewhere by me."

This species is credited to ('anada in Torres d Gray's Flora and in IIooker's Flora but no localities are mentioned. Both this and the next species are common in Michigan and that they have been $s$ recently found on the Canalian side of the Detroit River in a region that has been well 
botanized may go to show that they are extending their limits.

Ludwiata polycarpa, Short \& Peter.

Found by Prof. Macoun in 1891, growing in ditches and along the railway track near Amherstburg, Ont.

Grindelia squarrosa, Duval.

This common prairie plant has become naturalized in the vicinity of Skead's Mills near Ottawa, Ont., where it was found by Mr. Wm. Scott in 1890, the seed having been doubtless brought from the west either in grain or attached to cars of the Canadian Pacific Railway.

\section{Aplopappus Lyallir, Gray.}

This plant is probably to be found on most of the higher mountains in British Columbia but was overlooked unti! 1890, when it was collected in the Gold Range by Mr. Tas. Mctivoy and by the writer on a high mountain near Kicking Horse Lake in the Rocky Mountains.

That it was not collected before, is I believe to be attributed to its close resemblance to a form of Solidago multiradiata var. scopulorum, Gray, Common on all the mountains in British Columbia with which it was growing when found by me. With it Aplopuppus Brandeyei also grew and it was while collecting specimens of this plant that I noticed what appeared to be two forms of the Solidago referred to, but one of which proved on examination to be $A$. Lyallii.

This species was again found by P'rof. Macoun in August, 18:11, in abundauce on the mountains around Jake Agnes, near Laggin, Rocky Mountains.

Aster 'stenomeres, Gray.

Until 1890 confined, so far as known, to Idaho and Montana. In that year young plants were found by Prof. Macoun on a mountain near the Columbia River at sproat, B. ('., they were brought to eamp, placed in water and at the end of a week were in full bloom. 
Arnica Parryi, Gray.

Collected first at Kicking Horse Lake in the Rocky Mountains by Prof. Macoun in 1885 , but referred to $A$. toliosa. Igain collected at the same place in 1890, and correctly determinel and afterwards in 1891 at Iake 1 gnen and Lake Louise near Laygan, Rocky Mountains. New to Canada.

Hemicarpha subsquarrosa, Nees.

This minute sedge was found in 1891 by Prof. Macoun growing in damp sandy soil near Amberstbur'g, Ont. New to Canada. 



Contributions from the Herbarium of the Geological Survey of Canada.

(By Permission of the Director.)

$$
\begin{aligned}
& \text { By JIMEs M. MLATr'. } \\
& \text { renceter of the Horbariom. }
\end{aligned}
$$

II.

"Reprinted from the Canarlian Record of Scienne, Aprii, 1594." 

Contributions to Canadian Botany.

By JAs. M. MACotx. 
"Reprinted from the Canadlan Record of Science, April, 1894."

\section{Contributions to Canadian Botany.}

By JAs. M. MAcoun.

II.

\section{Thaziotrum Fenderi, Engelm.}

Kicking Horse Lake, Rocky Mts. 1890. (Jas. M. Macoun.) Only Canadian station.

Thaliotrum occidentale, Gray.

The western limit of this species is placed by Prof. Macoun (Cat. Can. Plants, p. 479) in the Selkirk Mts., B.C. Recent collections and a re-examination of our specimens have greatly extended its range. ${ }^{1}$ Mountains near Kootanio Lake, B.C.; Sproat, B.C.; Mountains near Griffin Lake, 13.C.; Nanaimo, Vancouvor Ieland. (John Macoun.) Mountains near Spence's Bridge, B.C. (Jas. M. Macoun.) Dean or Salmon River, B.C. (Dr. G. M. Dawson.)

Thaliotrum polygamum, Muhl.

T. Cornuti, Linn.

1 The Geographical limits given in these papers refer to Canada only. 
This species is confined to Eastern Canada and does not extend across the continent as stated in Macoun's Cat. Can. Plants, p. 15. Our most western specimens are from Flat Rock Portage, Lake Nipigon, Ont.

Thalictrom perporascens, Linn.

Long Lake, Assiniboia; Warm Springs, Kootanie Lake, B.C. (John Macoun.) Not before recorded west of Ontario. References under rar. ceriterum, Macoun's Cat. Can. Plants, p. 479 go here.

Thanictaum venulosum, Trelease.

Additional stations for this rare species are Manitoba Huuse, Lake Manitoba; Kicking Horse Lake, Rocky Mts. (John Macoun).

Thalictricm Dioiclu $\times$ PURPURagcens.

Specimens from Eel River, Restigonche, N.B., (R. Chalmers.) with leaves glandular and fruit intermediate bave been referred here by Dr. Trelease.

Note-All the specimens of Thalictrum referred to above hare been examined by Dr. Wm Trelease and our determinations contirmeal or corrected by him:

Anemone deltoidea, Dougl.

Specimens collected in the Coast Range by Dr. G. M. Dawson, were referred here by Prof. Macoun, (Cat. Can. Plants p. 13.) A recent examination of these specimens shews them to be A. Richarlsoni. A. deltoidea has not been found in Canada.

A NEMONE HEPATTCA, L.

A few leares collected by Dr. Robt. Bell on the Upper Sarage Islands, Hu lson stratt, (Macoun, Cat. Can. Plants, p. 7 -8), prove to be the root-leares of Saxifraga cernua and not A. Hepatica.

Angmone Lyalli, Britton, Annals of N. Y. Academy of Șciences, Vol. VI. p. 227. 
A. nemorosa, Linn., var. (?), Macoun, Cat. C'an, Plants, Vol. I, p. 478.

A. Oregana, Macoun, Cat. Can. Plants, Vol. II, p. 295.

Slender, erect, nearly glabrous throughout, $10-40 \mathrm{~cm}$. high, from a short horizontal root-stock. Radical leaves not seen: leaves of the involucre on very slender petioles 1.5-3 cm. long., 3-divided, the divisions sessile, ovate, or the terminal ones sometimes nearly orbicular, dentate-crenate, or sometimes incised, acute, or obtuse, very thin, more or less ciliate along the margins; flowers solitary white, about $1 \mathrm{~cm}$. broad, its peduncle slightly exceeding the petiols of the involucral leaves, sepals about 5, oval-oblong, obtuse; young achenia quite densely strigose-pubescent

Dean or Salmon River, B.C., (Dawson). Near Vistoria, V.I., (Fletcher), Goldstream, V.I., and Burnside Road near Victoria. V.I., (Macoun. Herb. Nos. 912, 913).'

ANEMONE QUINQUEFOLIA, L.

A. nemorosa, Amer. Author's.

"Readily distinguishable fiom the Furopean A. nemorosa by its slender habit, slender petioles, less lobed divisions of the involucral leaves, paler green of the foliage and smaller flowers." (Dr. N. L. Britton.)

The western limit of this species as shown by our herbarium specimens is Wingh:m, Ont.

Note. See Revision ol the genus Anemone by Dr. N. L. Britton in Annals of the New York Academy of Sciences, Vol. VI. pp. 215-238.

Aquilegia chrysantha, Gray.

On the portage between Hope and the head of the Similkemeen River, B.C., (A. J. Hill.), New to Canada.

Arabis Macounir, Watson, Proc. Am. Acad. of Arts and Sciences, p. 124.

Biennial, branched from the base, slender, pubescont

1 Whenever herbarium numbers are given, they are the numbers under which specimens have been distributed from the herbarium of the Geological Survey of Canada. 
below with mostly stellate spreading hairs, glabrous above or but sparingly puberulent, a foot high; leares small and narrow, $\frac{1}{2}$ inch long or less, the lower very rarely fewtonthed, the cauline sagittate at base; flowers very small, pale rose-colour, 2 lines long; pods very narrow, 1 to $1 \frac{1}{2}$ inches long and about $\frac{1}{2}$ line broad, glabrous, slightly curred, mostly diraricate on very slender pedicels 2 to 4 lines long, acute, the stigma noarly sessile; seeds (immature) approximately 1 rowed, apparently wingless; near A. hirsuta.

Gravelly bankis, Revelstoke, B.C., May 13th, 1890. (John Macoun.)

\section{Trifolitu procumbens, Linn.}

An erect form of this plant was found by Prof. Macoun in 1993, growing in tields at Comox, Vancourer Inland. Not recorded before from western Canada, though the rar. minus is common on Vancouver Island.

\section{Trifolium involdcratum, Willd.}

Collected at Revelstoke, B.O. in 1890 by Prof. Macoun. Abundant on Vancourer Island, bat not before collected in the interior of British Columbia.

\section{Trifolium mirrocephalua, Purrh.}

Collected at Rerelstoke and Sproat on the Columbia Rirer, B.C. in 1890 by Prof. Macoun. Common on Vancouver Island, but not before recorded from interior of British Columbia.

\section{LotUs CoRntovlatus, Linn.}

Recorded from New Brunswick. Collected in 1890 at Victoria, Vancouver Island, by Rev. Edw. L. Greene.

Astralagus Robbinsir, Gr. var. occidentalis, Wat.

Not before separated in Canada from A.alpinus, the western form of which it somewhat resembles. Bow Piver at Morley, Alberta ; near the Glacier at Lake Louise, Rocky Mts.; Deer Park, Columbia River, B.C. (John Macoun.) Gui- 
chon Creek, B.C. (Dr. G. M. Dawson.) All the above specimens were found growing on gravelly shores or banks.

Fragaria Canadensis, Michx.

This plant has been separated from $F$. Virginiana by Dr. N. L. Britton. (Bull. Torr. Bot. Club, Vol. XIX., p. 222.) At the time Dr. Britton's note was written our herbarium contained no specimens of this species. In 1892, however, it was collected by Miss E. Taylor at Fort Smith, on the Great Slave River, and in 1893 by $\mathrm{Mr}$. Jas. W. Tyrrell on the banks of the Black River, east of Lake Athabasca. "The leaflets are much narrower, oblong or the middle one obovate and cuneate at the base, all obtuso rather sparingly and not deeply toothed." In Miss Taylor's specimens the largest leaflet is 20 lines long and but 7 lines broad at its widest part. The plants here refured to are very much slenderer than any of our specimens of $F$. Virginiana. The stations given for this species by Dr. Britton are Lake Mistassini, (Michaux.) Aretic America. (Dr. Richardson.) Elk River [Athabasea River] (Kennicott.)

\section{EPILOBIUM, Linn.}

In the last addendum to his catalogue of Canadian Plants (Vol. II., p. 323), Prof. Macoun wrote: "Many additional species and varieties of Epilobium have been added to our flora since the publication of Part III, but our whole series of this genus is now being examined by P'rof. Trelease who is unable to report upon them in time to include them in this part." Since the above was written botanical explorations in the Rocky Mountains, British Columbia, and elsewhere have added greatly to our knowlerlge of this genus, and the revision here given covers all the specimens in our herbarium and gives the distribution of each species as we now understand it. All our specimens have been examined by $\mathrm{Dr}_{1}$. Wm. Trelease, and references to many of them have been included in his rovision of this genus. (See Second Annual Report, Missouri Botanic Gardens, pp. 69-116.) 
(1.) F. SPicatum, Lam.

Common from the Atlantic to the Pacific and north to the Arctic Circle. The most northern specimens in our herbarium are from the mouth of the Mackenzie River (Miss $E$. Taylor.) and from Lat. $60^{\circ} 20$, Long. $104^{\circ} 30$. (Jas. W. Tyrrell.)

\section{Var. CANescens, Wood.}

"An albino variety with more than usually canescent pods." Marmora Village. Hastings Co. and Owen Sound, Ont. (John Mucoun.) Lake of the Woods, Ont. (Burgess; Dauson.) Norway House, Lake Winnipeg. (Otto Klotz.)

(2.) E. IATtrolidM, L.

Newfoundlanil, Iabrador and the Gaspé Peninsula; Bow River, Rocky Mts., to the Pacific Coast and throughout Canada north of Lat. 53 . Most of the northern specimens in our herbarium are the broad-petaled variety grandiflorum, Britton. Specimens collected by Mr. Jas. W. Tyrrell in Lat. $64^{\circ}$ Long. $101^{\circ}$ were just coming into flower Aug. 25th, 1893. Albinos with very large cream-coloured flowers have been collected on both sides of Hudson Bay by Mr. Jas. M. Macoun.

(3.) E. HIRsuTuM, L.

Naturalized at Niagara Falls, Ont. (R. Cameron.) Introduced in garden seed.

(4.) E. IUtedr, Pursh.

Abundant by riculets and on damp grassy slopes in the Selkirk Mts., B.C., between Beaver Creek and the Glacier House, but not known to occur elsewhere in Canada. The potals are bright yellow a little lighter than those of Enothera biennis.

(5.) E. Panieulatum, Nutt.

Abundant at Colpoy's Bay, Georgian Bar, Lake Iuron. (John Macoun.), but not found in any other part of Eastern Canada. Rure in the prairie region, but common in British Columbia and on Vancouver Island. 
(6.) E. MinUtuM, Lindl.

From several localities in British Columbia and common on Vancouver Island. The form named adscendens by Suksdorf, was collected on Mt. Benson, Van. Island, by Prof. Macoun in 1893.

Var. rouiosum, Torr. \& Gray.

Sproat, Columbia River, B.C., (John Macoun) and Yale Mt., B.C., (Fletcher.) Common on Vancouver Island.

(7.) E. striotum, Muhl.

E. molle, Torr. of Macoun Cat. of Canadian Plants, p. 171 in part and p. 530.

Specimens in our herbarium are from East Pt., P.E.I., and Belleville, Ont. (John Macoun); Cartwright, Ont. (W. Scott.)

(8.) E. Lingare, Muhl.

Common from Prince Edward Island west to Beaver Creek, Selkirk M.ts., B.C.

(9.) E. palústre, L.

Common from the Atlantic to the Rocky Mts. No specimons in our herbarium from British Columbia, but found north of that province by Dr. G. M. Nawson on the Lewis River in Lat. $62^{\circ}$.

(10.) F. palustre $\times$ hineare. (E.pseudolineare, Hausskn.)

Spevimens collected by Prof. Macoun at Ellis Bay, Anticosti, have been referred here by Dr. Trelease.

(11.) E. Davuricum, Fisch.

"Habit of E. palustre; stems terete or with occasional low decurrent lines; seeds fusiform, prominently beaked."

A span or two high mostly simple, the very slender stem sparingly incurved-pubescent, otherwise glabrous; roots densely fascicled; leaves less than $15 \mathrm{~mm}$. long, somewhat crowded at base, alternate and remote above, linear or oblong, obtuse, remotely denticulate, sessile 1.nerved; flower's pale not very numerous, nodding; capsules erect 
$40 \mathrm{~mm}$., or long slender peduncles; seeds, $4 \times 1.5 \mathrm{~mm}$; coma white.

In bogs, Beaver Creok, Selkirk Mts., B.C., Aug. 14th, 1885. (John Macoun.) In one of these specimens "the beak of the seed is very narrow and $3 \mathrm{~mm}$. long."

(12.) E. Franciscanom, Barbey.

Of many of our specimens examined by Dr. Trelease, but one collected at Qualicum, Vancouver Island, has been definitely referred to this species. Of other specimens examined by him he says: "Specimens collected on Vancouver Island and in British Columbia are doubtfully referred here, though they may belong to adenocaulon. The smaller, more closely crisp-hairy form approaches the next species. [E. Watsoni.] A curious simple plant with large glossy thin leaves, scarcely to be referred elsewhere oceurs from Queen Charlotte Islands, B.C. (Dawson, July 10th, 1878.)"

Specimens collected by Prof. Macoun on Vancouver I8land in 1893 are placed here, though "too near E. adenocaulon var.occidentale." The specimens now referred to this species were formerly included under $E$. coloratum.

(13.) E. coloratoy, Muhl.

Represented in our herbarium by but one specimen from Casselman, Ont. All the eastern specimens placed under $E$. coloratum, and most of the western placed under $E$. coloratum and E. tetragonum in Prof. Macoun's Catalogue of Canadian Plants, (pp. 169-170) have been referred to $E$. adenocaulon by Dr. Trelease.

Specimens from Salt Lake, Anticosti; Little Flat, Rock Portage, Nipigon River, Ont., and Little Slave Lake, N.W.T., are probably coloratum $\times$ adenocaulon.

\section{(14.) E. adenocaulon, Hausskn.}

Common from the Atlantic to British Columbia. Dr. Trelease considers that a very small crisp-pubescent form ( $1 \frac{1}{2}$ to 3 inches in height), collected by Prof. Macoun at Brackley Pt., P.E.I., may be E. ciliatum, Raf. 
Var. occidentale, Trelease.

Lake Okanagan and Burrard Inlet, B.C., and common on Vancouver Island. "Sometimes comes too near E. Franciscanum, but differs in its usually smaller flowers less corymbosely clustered and more acute at base, and in its shorter glandular pubescence."

(15.) E. glandulosum, Lehm.

In damp places at an altitude of 5,000 feet at Warm Springs, Kootanie Lake, B.C. (John Macoun.)

(16.) E. BRevis'rylum, Barbey.

Specimens from mountains south of Tulameen River B.C. (Dawson), have been doubtfully referred here by Dr. Trelease.

(17.) E. Halleanom, Hausskn.

Collected by Prof. Macoun in 1887 on Cedar Hill, Vıncouver Island, and in 1893 at Fisquimault, V. I.

(18.) E. Drummondi, Hausskn.

Young specimens from Stewart's Lake, B. C., (Macoun) with leaves in whorls of 3 , have been doubtfully referred here by Dr. 'Trelease.

(19.) E. LeptocarpUM, Hausskn.

A span or less high, glabrous except for some incurved pubescence on the stem; leaves less than $20 \mathrm{~mm}$. long, broadly lanceolate, sparingly low-toothed, tapering from near the middle to the obtuse or subacute apex and winged petiole; flowers abundant for the size of the plant; calyxtube narrow; petals about $3 \mathrm{~mm}$. long, rosy; capsules 20 $\mathrm{mm}$., on very slender peduncles of nearly equal length ; seeds nearly ellipsoidal, shortly hyaline beaked, $25 \times 75$ mm.; coma at length cinnamon-colored.

\section{Var. Macouni, Trelease.}

Less branched, crisp-pubescent in lines, the same pubescence more or less abundant also on the flowers and eap. sules; leaves more ovate; seeds $1 \mathrm{~mm}$. long; coma paler. 
New variety first collected in 1878 near Lake Athabasca by Prof. Macoun, for whom it is named, and again by him at the head of Lake Louise, Rocky Mts., in 1891.

(20.) E. Hornemanni, Reichenb.

Nearly all the references under E. origanifolium, Lam., Macoun's Catalogue of Canadian Plants, p. 169, belong here.

In one or other of its forms from Labrador to Vancouver Island.

(21.) E. Ацpinum, L.

From Kicking Horse Lake to Vancouver Island. Generally found with the preceding species which it greatly resembles. E. Hornemanni is "somewhat crisp-hairy in the inflorescence and along the decurrent lines or slightly glandular at top, otherwise glabrate"; in $E$. alpinum the inflorescence and decurrent lines are more nearly glabrous. In the former species the seeds are "rather abruptly shortappendaged, from nearly smooth to very rough;" in the latter they are "smooth gralually alternated at apex with very evident beak."

(22.) E. Oregongnse, Hausskn.

Border's of rivulets, Swamp River, B.C. (Macoun.) Only Canadian station.

(23.) E. anagaldidifolium, Lam.

Specimens in our herbarium are from ('ape Chudleigh, Hudson Strait. (Dr. Bell.) Rocky Mts. (Drummond.) Kicking Horse Lake, Rocky Mts., and Mt. Benson, Vancouver Island. (Macoun.)

(24.) E. clavatum, Trelease.

A span high, mostly densely crespitose, the slender stems ascending, glabrate to sparingly glandular throughout; leaves 15 to $20 \mathrm{~mm}$. long, divergent, broadly ovate, very obtuse, subentire to remotely serrulate, mostly rounded to evident petioles, firm, drying brownish ; flowers rather few, suberect, petals rose-colored, about $5 \mathrm{~mm}$. long; capsules 25 mm., subclavate arcuately divergent, the lowest often not 
reaching the apex of the stem, their slender peduncles equalling the subtending leaves; seeds fusiform, tapering into a pale beak, nearly smooth to coarsely papillate, 4 to $.6 \times 1.5$ to $2 \mathrm{~mm}$. ; coma barely dingy.

First collected in Canada by Jas. M. Macoun in 1890, al an altitude of 7,500 feet on mountains near Kicking Horse Lake, Rocky Mts. In 1891 by Prof. Macoun on several mountains near Banff and Lake Louise, Rocky Mts.

\section{Angelica Iratim, Wat.}

Specimens collected by Dr. Geo. M. Dawson on the summit of the South Kootanie Pass in 1891, were doubtfully referred here by Prof. Macoun (Cat. Can. Plants, Vol. I., p. 535.) These specimens have sinee been examined by Coulter and Rose, who confirm his determination. This species has since been found at Sproat, Columbia River, B.C., 1890, (John Macoun) and at Chaperon Lake, B.C., (Jas. McEvoy.)

Echium vULGare, Linn.

Though well naturalized and spreading in Canada, east of the great Lakes, of very local occurrence in the west. Our western specimens are from Wabigon Tank, on the C. P. Railway, east of Lake of the Woods, (W.m. McInnes) and Cariboo, B.C. (John Macoun.)

Mentha Canadensis, $I$.

Colquitz River, near Victoria, V. I., and Sooke, V. I., 1893. (John Macoun, Herb. Nos. 1054, 1055.) Not before recorded from Vancouver Island.

Mentha Canadensis, L. var. glabrata, Benth.

Fort Simpson, Mackenzie River. (Miss E. Taylor.) Sproat, B.C.; Kamloops, B.C.; Sproat Lake, Vancouver Island. (John Macoun.) Not before recorded west of Rocky Mountain8.

Nepeta Cataria, L.

Beacon IIill, near Victoria, Vancouver Island, 1893. (John Macoun, Herb. No. 977.) Not before recorded west of Ontario. 
Stachys ciliata, Dougl. var. Pebens, Gray.

New Westminster, B.C., 1892. (Law.) Fishery Baj. Nasse River, B.C. (Jas. McEvoy, Herb. No. 1096.) Our only otber specimen is from Queen Charlotte Islands.

Mentha viridis, L.

Growing in the streets of Vicloria, Vancouver Island. 1893. Naturalized. (John Vacoun, Herb. No. 1052.)

Asarual caudatum, Lindl.

Common at Revelstoke, B.C. (John Macoun.) Eastern limit in Canada.

\section{Epipactis Helleborine, Crantz.}

First found in Canada in 1890 at Lambton Mills, IIumber River; Ont., by W. \& O. White, and more recently (1892) on Mount Royai, Montreal, Que., by N. D. Keith.

The only stations given for this species in the last edition. of Gray's Manual are Syracuse and Buffalo, N.Y.

Eplpactis gigantea, Dougl.

Collected by Dr. G. M. Dawson in 1877 at Osoyoos Lake, B.C., but not again until 1890, when it was found by Prof. Macoun at Lower Arrow Lake, Columbia River, and Hot Springs, Kootanie Lake, B.C.

Aluium Nevi, Watson.

Found growing on gravelly banks at Botanie near Spence's Bridge, B.C., by Jas. McEroy. Found on Vancouver Island, but not before on the mainland.

Juncus Grarard, Iois.

This rush, though common on the Atlantic Coast, had not been found on the Pacific Coast until it was discorered in 1887 by Prof Macoun near Victoria, Vancouver Island. It was again collected by him at Nanaimo, V. I. in 1893. As in the east it was found growing in salt marshes and is without donbt indigenous. 
Potamogeton natans, Linn.

Enderby, B.C., and Shuswap Lake, B.C. (Jas. M. Macoun.) Griffin Lake, B.C., and Revelstoke, B.C. (John Macoun.) Not before recorded from British Columbia.

Potamogeton padciflorus, Pursh.

Revelstoke, B.C., 1890. (John Macoun.) Not befure recorded from British Columbia.

Botrychium lanoeolatum, Angst.

Near Niagara Falls, Ont. (R. Cameron.) Not before found in Ontario. 



Contributions from the Herbarium of the Geological Survey of Canada.

(By Permission of the Director.)

By JAMES M. MACoun,

Curator of the Herbarium.

III.

Reprinted from the Canadian Record of Science, November, 1894. 


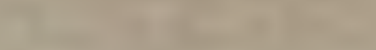

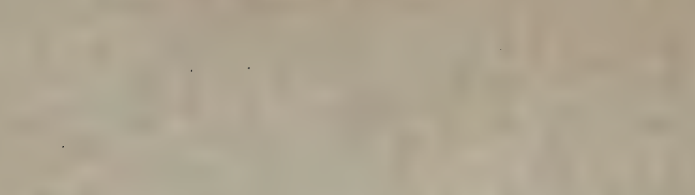

9

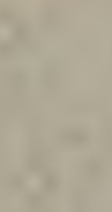




\title{
Contributions to Canadian Botany.
}

\author{
By JAs, M. Macoune
}

III.

Ranuncultg abortives, I., var. micranthus, Gray.

Our only specimens of this species are from Quesnelle, B. C. (John Macoun.)

Ranuncults aquatilis, L., var. trichophyllug, Gray.

Cedar IIill, Alberni, and Comox, V.I. (John Macoun.) Not recorded before from Vancouver Island.

Ranunculus acris, Linn.

Foot of Devil's Lake, Rocky Mts. ; Griffin Lake, B. C.; Revelstoke, B. C. (John Macoun.) Not before recorded west of Manitoba.

Ranunculus bülbosus, $L$.

Revelstoke, B. C. (John Macoun.) Only record west of Ontario. $^{1}$

Ranunculus orrcinatus, Sibth.

R. aquatilis, L., var. stagnatilis, DC., Macoun, Cat. Can. Plants, Vol. I., p. 16, Vol. II., p. 296.

Patterson's Creek, Ottawa, Ont. (W. Srott.) Wingham, Ont. (J. Morton.) Sturgeon Lake, Nipigon River, Ont. (John Macoun.) Not before recorded east of Manitoba.

Ranunculus Crmbalaria, Pursh.

Departure Bay, V. I. ; Courtney River, Comox, V. I. (John Macoun.) Not before recorded from Vancouver Island.

Rancnculus Cymbalaria, Pursh., var. alpinus, Hood.

Minute specimens of this variety were collected by the Rev. A. Waghorne, in 1891, at Venison Tickle, Labrador, and on Prince Edward Island, in 1893, by Mr. W. J. Wilson. Our only other specimens are from Anticosti.

The Geographical limits given in these papers refor to Canada only. 
RanUnOULUS HEDeraofes, $\mathrm{L}$.

In wet places, Newfoundland, 1891, 1892 . (Rev. A. Waghorne.) Only Canadian station.

RAnUndulds hyperboreus, Rottb.

Pack's Harbour and Venison Tickle, Labrador. (Rev. A. Waghorne.) Specimens collected by Dr. Robert Bell at Cape Chudleigh, Hudson Strait, and referred to $R$. pygmoeus (Macoun, Cat. Can. Plants, Vol. I., p. 480), are of this species.

Ranunculus Macounir, Britt., Trans. N. Y. Acad. of Seience, Vol. XII., Nov., 1892.

R. repens, Linn., var. hispidus, Macoun, Cat. Can. Plants, Vol. I., p. 21 in part.

R. hispidus, Macoun, Cat. Can. Plants, Vol. II., p. 298.

This species includes most of our western specimens that had been referred to $R$. hispidus $\mathrm{Mx}$. Our horbarium specimens are from Nipigon, Lake Superior; Pheasant Plain, Cypress Hills, and Crane Lake, Assin.; Red Deer River, Alberta; Wigwam River, Rocky Mts.; Donald, Columbia River, B. C. ; Sproat, B. C. ; Port Haney, B. C.

Ranunoulus natans, C. A. Mejer.

New Westminster, B. C. (John Macoun.) The western limit of this species in Canada.

Ranunoulus pyemaus, Wahl.

Summit of Mt. Aylmer, Devil's Lake, Rocky Mts. Alt. 8,300 ft. (John Macoun.) Rare in Canada.

IsOpyrum BITKRnATUM, T. \& G.

Not rare in the vicinity of London, Ont. (J. Dearness.) New to Canada.

Caltha palugtris, L., var. Sibirica, Regel.

C. asarifolia, DC.

Lulu Island, mouth of Fraser River, B. C., 1889 ; Courtney River, Comox, Vancouver Island, 1893. (John Macoun.) Growing in salt marshes at both stations. Leaves reniformcordate, with the sinus very obtuse (some leaves without 
sinus). No form of $C$. palustris before recorded west of Rocky Mountains.

Coptis trifolia, Salisb.

Damp woods, Mt. Mark, Vancourer Island. Alt. 3,000 ft. (John Macoun.) Not before recorled west of Rocky Mts.

Coptis asplentoroli, Salisb.

Port Simpson, B. C. (Jas. McEvoy.) In marshes, near Union Mines, Comox, V. I. (John Macoun.) Not before rocorded from Vancouver Island.

A quilagia brevistrua, Hook.

The following are new stations for this species: Severn Lake, Keewatin; Fort Mc.Murray, Athabasca River (Jas. M. Macoun); Fort Good Hope, Mackenzie River (Miss $E$. Taylor); Francis River, lat. $61^{\circ}$ (Dr. G. M. Dausson).

Delphimtum Ajacis, L.

Escaped from cultivation and naturalized at Lake Scugog, Ont. (W. Scott.)

Act.fa spicata, L., var. arguta, Torrey.

Prof. Macoun describes this as the "British Columbia form." We have it also from the Rocky Mountains and Vancourer Island-Levil's Lake, Rocky Mts.; Cameron Lake and vicinity of Victoria, V. I. (John Macoun.) Prof. Macoun gives the range of $A$. alba as from Nova Scotia "through the wooded courtry to the Coast Range in British Columbia." Our most western station for this species is Nipigon, Lake Superior. Western specimens that were referred here prove to be the white-berried variety of $A$. spicata, var. arguta.

Nigelua Damarcena, I.

Escaped from cultiration and naturalized along roadsides, Wingham, Ont. (J.A. Morton.)

Berberis aquTroulum, Pursh.

Revelstrke and Deer Park, Columbia River, B. C. (John Macoun.) Eastern limit in Canada. 
PAPAVER gomnifgrum, Linn.

Escaped from cultivation and naturalized at Sicamous, B. C. (John Macoun.)

Esohroholtzia Californioa, Cham.

Naturalized and spreading in the vicinity of Victoria, Vancouver Island. (John Macoun.)

Corydalis glauca, Pursh.

Recent explorations have greatly extended the limits of this species as given by Prof. Macoun (Cat. Can. Plants, Vol. I., p. 36). New stations are: Summerside, Prince Edward Lsland; Beaver Creek, Selkirk Mountains, B. L.; Revelstoke, B. C.; Griffin Lake, B. C. (John Macoun) Rupert River, N. E. Te:. (Jas. M. Macoun); Hast Main River, N. E. Ter. (A. Ross); Fort Grood 1lope, Mackenzie River (Miss E. Taylor); north shore of Lake Athabasca, N. W. T. (Jas. W. Tyrrell).

Corydalis aurea, Willd,, var. occidentalis, Gray.

New stations for this plant are: Okonagan Lake, B. C. (J. McEvoy); Kamloops, B. C. (John Macoun); Telegraph Creek, B. C., lat. $58^{\circ}$ (Dr. G. M. Dawson).

Nasturtium palustre, DC, var. ocoidentale, Wat.

Sproat, B. C. ; Courtney Village, near Comox, Vancouver Island. (John Macoun.) References under N. palustre, DC., var., in Macoun's Cat. Can. Plants, Vol. II., p. 300, go here.

Nasturtiom OfFicinale, $\mathrm{R}$. Br.

In rivulets and pools, Banff, Rocky Mts.; in springs on Sea's farm, near Victoria, Vancouver Island. (John Macoun.) Not before recorded west of Ontario.

Nasturtium Indroum (L.), DC.

Specimens found growing on ballast heaps at Nanaimo, Vancouver Island, by Prof. Macoun, in 1893, have been doubtfully referred here by Dr. N. L. Britton. Whatever this plant may prove to be, it is a species new to Canada. 
Barbarea vulgaris, R. Br, var. arcuata, Koch.

Finlayson River, lat. $61^{\circ}$. (Dr. Geo. M. Dawson.) Revelstoke, B. C. (John Macoun.) Most northerly and easterly stations for this variety.

Arabis CONFINIs, Wat.

Fort Simpson and Peel's River, Mackenzie River. (Miss E. Taylor.) Our most northerly specimens.

Arabis himforsa, var. pubescens, Wat.

North shore of Lake Athabasca, N. W. T., 1893. (J. W. Tyrrell.) Our only other specimens are from Hudson Bay.

Arabis Lyallit, Wat.

Prof. Macoun (Cat. Can. Plants, Vol. I., p. 487) places the western limit of this species at the summit of the Selkirk Mts. More westerly stations are Toad Mt., Kootanie Lake, B. C. alt. 5,500 ft., and I.t. Queest, Shuswap Lake, B. C., alt. 6,000 ft. (Jas. M. Macorn.)

Cardamine Breweri, Wat.

C. pratensis, L., var. occidentalis, Macoun, Cat. Can. Plants, Vol. II., p. 601.

In springs and ditches, Goldstream, Victoria, Comox and Nanaimo, Vancourer Island. (John Macoun.) New to Canada. Specimens of this plant collected by Prof. Macoun at Nanaimo, in 1857. were called C.pratensie, var. occidentalis, by 1)r. Watson. I recent comparison of our specimens with the type at Harvard, by Prof. Macoun, shows our plant to be C. Brewceri.

Cardayine pratensis, Linn., var. angristifolia, Hook.

North shore of Lake Athabasca, N. W. T. (Jas. W. Tyrrell.)

I)raba nivalis, Jacq., var, elongata, Wat.

First collected on the mountains at Kicking Horse Lake by Prof. Macoun in 1885 , and referred to $D$. stellata, Jacq. Other stations are Kicking Horse River, Rocky Mts., alt. 4,000 ft., and Koger's Pass, Selkirk Ifts., alt. 5,500 ft, 1890. (Jas. M. Macoun.) Mountains near Banff, Rocky Mountains, 1891. (John Macoun.) 
Sistmbridu Alliari, L.

Naturalized along roadsides in Beechwood Cemetory, Ottawa, Ont., 1891. (W. Scott.) Only Canadian station known to us.

Sisymbridu officinale, Scop.

Prof. Macoun (Cat. Can. Plants, Vol. I., p. 46) limits the distribution of this species to Ontario and the eastern provinces. It has been since found at Sicamous, B. C..; Nelson, Kootanie Isake, B. C. ; Esquimault and Nanaimo, Vancouver Island. (John Macoun.)

Sistmiridum sinapistrom, Crantz.

First noted in 1885 along the Canadian Pacific Railway in the Rocky Mountains. It has since become one of the most troublesome weeds in Manitoba and Assiniboia. Its western limit, as shown by our specimens, is Roger's Pass, Selkirk Mts.. B. C. It is noteworthy that this plant thrives equally well on the dry prairies and at the summit of the Selkirk Mountains, where seldom a day passes without rain. Erysimum orientale, $\mathrm{R}$. $\mathrm{Br}$.

Collected at Castle Mt., Rocky Mts., in 1885, by Prof. Macoun, but not recorded, and, in 1891, at the foot of Devil's Lake, Rocky Mts. Probably introduced at the time the Canadian Pacific Railwry was being constructed, and now thoroughly naturalized. Mr. Jas. Fletcher reports that this plant has become a troublesome weed in many parts of the North-West.

ERYisimum ParViflorum, Nutt.

Rocky fields, Chaudière, near Ottawa, Ont. (W. Scott.) Probably introduced from the west in grain. We have no other record east of Manitoba.

Brassica campestris, Linn.

Ottawa, Ont. (Wm. Macoun.) Waste places, Golden, B. C., and Revelstoke, B. C. (John Macoun.)

Bragsica campestris, L., val. oliefera, I)C.

Waste places, Ottawa, Ont. (W. Scott.) 
Brassica ginapistrem, Boiss.

Prof. Macoun gires Ontario as the western limit of this species. We have now specimens from Fort Walsh, Alberta ; Kananaskis, Rocky Mts.; Sicamous, B. C.; Cedar Hill, Vancouver Island. (John Macoun.)

Brassica Rapa, L.

Escaped from cultivation and naturalized in many parts of Canada. Yot included in Prof. Macoun's Catalogue. Our specimens are from Yarmouth, N. S.; Kamloops, B. C. ; waste places, North Arm, Burrard Inlet, B. C. ; fields and meadows, Cedar Hill and Beacon Hill, Vancouver Island; meadows at Comox and on ballast heaps at $\mathrm{Na}$ naimo, Vancouver Island. (John Macoun.)

Brassica al ba, Gray.

On ballast heaps at Nanaimo, Vancouver Island. (John Macoun.) Not before recorded west of Ontario.

Brassica nigra, Koch.

On ballast and in waste places, Nanaimo, Vancouver Island. Well naturalized, as it was found in 1887 and 1893. (John Macoun.) Not before recorded west of Ontario.

Capselila divaricata, Wahl.

Northeast coast of Newfoundland. (Rev. A. Waghorne.) Dead Islands, Labrador. 1882 (J. A. Allen.) Dry ground, Kamloops, B. C. (John Macoun.) Our only other specimens are from Spence's Bridge, B. C.

Lepidium sativuar, $\mathrm{L}$.

In cultivated fields near Victoria and at Sooke, Vancouver [sland. (John Macoun.) Not before recorded west of Winnipeg, Man.

Thlaspi ARVEnBE, L.

This weed grows yearly more troublesome throughont the Northwest. It has now crossed into British Columbia, being well distributed along the line of the Canadian Pacific Railway at the summit of the Selkirk Mountains. 
Raphands Raphanistrum, Linn.

Naturalized in fields at Agassiz, B. C., and in wasto places at Esquimault and Cedar Hill, Vancouver Island. (John Macoun.)

Spiesia(Oxytropis) Belli, Britton, n. sp.

Acaulescent, tufted, loosely villous, with white hairs. Stipules membranaceous, ovate or oblong, acute or acuminate, imbricated, villous or glabrate, $5^{\prime \prime}-7^{\prime \prime}$ long; leaves 3 ' $-6^{\prime}$ long; leaflets oblong or oblong-lanceolate, subacute at the apex, rounded at the base, $3^{\prime \prime}-4^{\prime \prime}$ long, $1^{\prime \prime}-2^{\prime \prime}$ wide; in verticils of three or four; peduncles about equalling the leaves; inflorescence capitate; pods oblong, erect-spreading, densely pubescent, with black hairs or some longer whitish ones intermixed, about $9^{\prime \prime}$ long and $3^{\prime \prime}$ in diameter, about three times as long as the black-pubescent ealyx, very nearly or quite two-celled by the intrusion of the ventral suture, their tips erect; corolla not seen.

Digges' Island, Hudson Bay ( $R$. Bell, 1884); Chesterfield Inlet, Hudson Bay (J.W. Tyrrell, 1893). Types in the herbarium of the Geological Survey of Canada.

The only other North American species thus far described with verticillate leaflets is $S$. splendens, with which the one here proposed has but little affinity. There are, however, a number of northern Asiatic species sharing this character, but I anc unable to refer the Hudson Bay plant to any of them. (N. L. Britton.)

\section{Cerois Canadensis, L.}

Pelee Island, Lake Erie. (John Macoun.) One tree of this species was pointed out to Prof. Macoun in 1892. An old resident remembered having seen this tree in his boyhood, but knew of no other on the island. It grows close beside the lake, and is doubtless indigenous.

MYRTOPHYLLUM ALTERNIFOIUM, DC.

Brigham's Creek, near Hull, Que., 1891. (W. Scott.) The only other Canadian station is Lake Memphramagog, Que. 
Pedcedandir micolor, Wat.

Hillsides at Sproat, Columbia River, B. C., 1890. (John Macoun.). New to Canada.

Peucedanum ambigudu, Nutt.

Hillsides at Deer Park, Columbia River, B. C. (John Macoun.) Eastern limit in Canada.

Linnaf borealis, Gronov., var. longiflora, Torr.

In woods on both sides of Lower Arrow Lake, Columbia River, B. C., 1890. (John Macoun.) First record from interior of British Columbia.

LONICERA C eRULEA, Linn.

Vicinity of Wingham, Ont. (J.A. Morton.) Our only record for Ontario east of Lake Superior.

Aster ptarmicoides, Torr. \& Gray, var. Lctescens, Gr.

Dry prairies, Indian Head, Assiniboia, 1893. ( $F$. G. .Maricood.) Not collected since 1872, when it was found by Prof. Macoun in the Touchwood Hills, N. W. T.

Antennaria luztloides, Torr. \& Gray.

Common on the hills behind Deer Park, Columbia River, B. C., 1890. (John Macoun.) Rare in Canada.

Lepachys columaris, Pursh.

Skead's Mills, near Ottawa, Ont. (W. Scott.) A common prairie plant introduced from the west by the Canadian Pacific Railway.

Arnica cordifolia, Hook, var. kradiata, Gray.

In woods, Little Shuswap Lake, B. C., 1889; Deer Park, Columbia River, B. C., 1890. (John Macoun.) New to Canada.

Lactuca sgariola, L.

Naturalized along the bank of the Niagara River and in waste places at Niagara, Ont. (R. Cameron.) Abundant around Windsor and Chatham, Ont., and as far east as Smith's Falls, Ont., 1894. (John Macoun.) 
Vaccinidm Corymbosum, Linn., var. pallidum, Gray.

At Stamford and "The Whirlpool," Niagara River, Ont., 1891. (John Macoun.) First record west of Nova Scutia.

Linaria ctmbataria, Mill.

Naturalized at Wingham, Ont. (J. A. Morton.) Our only other station in Canada is St. John, N. B.

Linaria Canadensis, Dumont.

Collected at Nanaimo, Vancouver Island, in 1893, by $\mathrm{Mr}$. Wm. Scott. Not elsewhere known in Canada west of New Brunswick.

Conobea multifida, Benth.

Growing in wet gravel at South Point, Pelee Island, Lake Erie, 1892. Not uncommon. (John Macoun.) New to Canada.

VERONICA CHAM ADRYS, Linn.

Naturalized at Niagara Falls, Ont. (R.Cameron.) First record west of Quebec.

Micromeria Douglasir, Benth.

Along the edge of rocky woods at Hot Springs, Kootanie Lake, B. C., 1890. (Jas. M. Macoun.) Between Shuswap Lake and Enderby, B. C., 1891. (Jas. McEvoy. Herb. No. 1234. $)^{1}$ Not rare on Vancouver Island, but not before recorded from interior of British Columbia.

Podostemon ceratophyluds, Michx.

Very abundant on flat limestone rocks in Brigham's Creek, Hull, Que. Collected by Prof. Macoun, Aug. 29th, 1894. Not before collected in Canada.

URTIOA URENS, Linn.

Along the Dallas Road, Beacon Hill, Victoria, Vancouver Island, 1893. (John Macoun.) First record west of New Brunswick.

${ }^{1}$ Whenever berbarium numbers are given, they are the numbers under which specimens have been distributed from the herbarium of the Geological Survey of Canada. 
Salix arbugculoides, Andr.

Specimens of this rare and little known willow were collected in 1893 by Mr. J. W. Tyrrell on the barren grounds between Lake Athabasca and Chesterfield Inlet. (Herb. No. 1716.) Our only other specimens of this species were collected by Dr. Richardson.

SALIX BaL BAMIFERA, Bartatt.

Barren grounds between Lake Athabasea and Chesterfield Inlet, 18!3. (J.W. Tyrrell. Herb. No. 1715.) Not before recorded north of the Saskatchewan.

SALIX Richardsoni, Hook.

One specimen of thị rare willow was collected by Mr. J. W. Tyrrell at Chesterfield Inlet Hudson Bay, in 1893. Not before recorded from vicinity of Hudson Bay.

SALiX PHYllicirolia, Linn.

We have specimens of this willow from several stations between Lake Athabasea and Chesterfield Inlet, collected in 1893 by MLr. J. W. Tyrrell, so that it is probably common throughout that region. Specimens collected in the vicinity of Hudson Strait by Dr. Robert Bell, and referred to S. chlorophylla, Andrs., by Prof. Macoun (Cat. Can. Plants, Vol. I., p. 446), are of this species.

Listera Borealis, Morong, Bull. Torr. Bot. Club, Vol. XX., p. 31.

Stems very delicate, $3^{\prime}-5$ ' high, glabrous below, glandularpubescent, and with long, silky, scattered hairs among the inflorescence, sheathed by two obture, membranous scales at the base; roots thickened, somewhat fleshy; leaves oval, slightly sheathing, obtuse at the apex, $4^{\prime \prime}-8^{\prime \prime}$ long, $2^{\prime \prime}-1^{\prime \prime}$ broad, entire, bearing on the surface a few silky hairs, otherwise very glabrous. Raceme two- or threeflowered. Bracts scarcely $1^{\prime \prime}$ long, much shorter than the pedicels. Sepals and petals nearly equal, linear, obtuse, about $2^{\prime \prime}$ long, lip $4^{\prime \prime}-5^{\prime \prime}$ long, $2^{\prime \prime}$ broad at the obtuse apex, ciliolate above ; apical lobes very obtuse, $1^{\prime \prime}$ long, the intermediate tooth obsolete; basal lobes $\frac{1}{2}{ }^{\prime \prime}$ long, very obtuse. 
Column slightly incurved, $1 \frac{1}{2}$ " long. Flowers greenish. yellow, the lip with a purplish middle, and purplish nerves radiating into the apical lobes. The flowers and column, as well as the leaves and upper stem, bear the silky hairs mentioned, some of which are $2^{\prime \prime}$ long.

Collected by Miss E. Taylor at Fort Smith, Great Slave River, in 1892.

Phalaris minor, Retz.

On ballast heaps at Nanaimo, Vancouver Island. (John Macoun. Herb. No. 323.) New to Canada.

Agrostis inflata, Scribner, n. sp.

Culms rather stout, 3-5 inches high, branched below. Sheaths smooth, striate-veined, much exceeding the internodes, inflated, especially the uppermost, which partially encloses the short (1-2in.), densely flowered panicle. Ligule prominent. Leaf-blade flat, $\frac{1}{2}-2 i n$. long. Spikelet $1 \frac{1}{2}$ lines long. Empty glumes lanceolate, awn-pointed, especially the second one, scabrous on the keel. Flowering glume about half the length of the empty ones, slenderawned on the back near the middle, awn exceeding the glumes, callus minutely hairy on the anterior side.

Described from specimens collected on rocks at Esquimault, Vancouver Island, by Prof. John Macoun, June 9th, 1893. (Herb. No. 258.) More mature, rather shorter and stouter specimens, with slightly broader, more striateveined sheaths, were collected on rocks at Beacon Hill, Vancouver Island, August 7th, 1893. (Herb. No. 259.)

Prof. Scribner further writes: "The spikelets in this grass are very nearly those of Agrostis microphylla, Steud., and it may prove to be only a much depressed form of that species." But this does not seem to me probable. An examination of our specimens of $A$. microphylla from Oregon, Washington, and British Columbia shows nothing like these plants, with the exception of specimens collected by Dr. G. M. Tawson on Texada Island, Gulf of Georgia, which answer well to the description of $A$. inflata, though a little taller. 
Avena strigosa, Schreb.

A weed in cultivated fields near Sooke, Vancouver Island, 1893. (John Macoun. Herb. No. 48.) New to Canada.

Poa trivialis, L., var. Filicliars, scribner, new var.

('ulms smooth, very slender from a creeping rhizome, radical leaves short, those of the culm 1-2 inches long, a line wide or less, acute, scabrous; ligule 2 lines long, acute. P'anicle 1-2 inches long, pyramidal. Spikelets two-flowered, $1 \frac{1}{2}$ lines long, much longer than the pedicels. Empty glumes very acute, narrow-lanceolate, the first one-nerved a little shorter than the three-nerved second glume, hoth scabrous on the sharp keel. Flowering glume $1 \frac{1}{4}$ lines long, acute distinctly five-nerred, pubescent on the sharp keel for one-half its length, and with a cobwebby tuft at base.

In wet meadows at Comox, Vancouver Island, 1893. (John Macoun. Herb. No. 282.) 






\section{Contributions from the Herbarium of the}

Geological Survey of Canada.

(By Permission of the Director.)

By JAMes M. MAcovN,

Curator of the Herbarium.

IV.

Reprinted from the Canadiun Record of Science, January, 1895. 

Contributions from the Herbarium of the Geological Survey of Canada.

(By Permission of the Director.)

By James M, Macoun,

Curctor of the Herbarium.

$$
\text { IV. }
$$

Reprinted from the C'unadian Recoird of Science, January, 1895. 


\title{
Contributions to Canadian Botany.
}

\author{
By Jas. M. Macoun.
}

IV.

Viola blanda, Willd, var. Amena (Le C.) B.S.P.

Seldom separated from the species by Canadian collectors. North Bay, Ont. (Dr. and Mrs. Britton and Miss Millie Timmerman.) Ottawa. Ont. (James Fletcher.) Wingham, Ont. (J. A. Morton.) The var. palustriformis, Gray, we consider but a larger form of the species under which we include our large stoloniferous specimens that are not certainly referable to var. amcena. They are from Edmonton, Ont. (Jas. White.) Wingham, Ont. (J. $A$. Morton.) Ottawa, Ont. (J. M. Macoun.)

Viola Canadengis, Linn.

Our most northern specimens of this species are from the Athabasca River. (Miss E. Taylor.)

Viola palustris, Linn.

Between Lake Athabasca and Chesterfield Inlet in Lat. $61^{\circ} 35$, Long. $103^{\circ} 30$. (Jas. W. Tyrrell). Northern limit in Canada as shown by our specimens.

Viola Selkirki, Pursh.

Battle Harbor, Fox Cove, Labrador, 1892. (Rev. A. Waghorne.) Northern limit in Canada. 
Polygala verticillata, Linn.

Sandy roil at (iriswold, Man. (W. A. Burman.) Only station west of Ontario. ${ }^{1}$

Dianthus Armerta, Linn.

On rocks, Victoria Arm, Vancouver Island. Naturalized and sprearling. In fruit July 21st, 1893. (John Macoun.) Not before recorded west of Ontario in Canada or Michigan in U.S.

\section{Dianthus barbatus, Linn.}

Fscaped from cultivation and naturalized at Hot Springs, - Kóntanie Lake, B.C., 1890. (Jas. M. Macoun.)

Saponaria VACCARIa, Linn.

A weed in gardens at Kamloops, B.C. Roadsides, Nelson, Kootanie Lake, B.C.; Cameron Lake, Vaneouver Island. (John Macoun.) Not before recorded west of the Columbia River.

Stlgnr A Rmeria, Linn.

Spontaneous in gardens at Rupert House, James Bay. (Jas M. Macoun.) Our most northern record.

Silgne Cucubalus, Wibel.

Naturalized near Spray Falls, Banff, Rocky Mountains. (John Macoun). Not before recorded west of Ontario.

Silene Douglasir, Hook,, var, Macounir, Robinson, Proc. Amer. Acad. xxviii, 144.

Lychnis elata, Macoun, Cat. Can. Plants, Vol. I, p. 69. Silene muliticaulis, Macoun, Cat. Can. Plants, Vol. I, p. 494.

S. Macounii, Wats., Proc. Amer. Acad. xxvi., 124.

Our herbarium specimens of this variety are from Mt. Aylmer, Rocky Mts., alt. 6,800 ft.; Lake Louise, Rocky Mlt.; Silver City, Rocky Mts.; Kicking Horse Lake, Rocky Mts., alt. 7,000 ft.; mountains north of Griffin Lake, B.C., alt. 6,500 ft. (John Macoun.) MIt, Queest, Shus-

${ }^{1}$ The Geosraphical limits given in these papers refer to Cansda only. 
wap Iake, B.C., alt. 6,000 ft. ; Avalanche Mt., Selkirk Mts., B.C., alt. 7,0 $0 \mathrm{ft}$. (Jas. M. Macoun.) Western Summit of North Kootanie Pass, Rocky Mts.; South of Tulameen River, B.C., alt. 6,000 ft.. (Dr. G. M. Dawson.) A part of the specimens referred to this variety are perbaps intermediate between it and the next.

Silene Douglasir, Hook, var. viscida, Robinson, Proc. Amer. Acad. xxvii, 145.

On slopes of high mountains at Kicking Horse Lake, Rocky Mts. (John Macoun.)

Silene Douglasir, Hook., var. multicaulis, Robinson.

S.. multicaulis, Macoun, Cat. Can. Plants, Vol. II., p. 309. Stump Lake, South of Kamloops, B.C. (John Macoun.)

Siliene Gallioa, Linn.

Common at Oak Bay, Goldstream and Victoria Arm, Vancouver Island. (John Macoun.) Introduced.

Silene noctiflora; Linn.

$\Lambda$ weed in gardens at Rupert's House, James Bay. (Jas. M. Macoun.) In waste places at Revelstoke, B.C., and Cedar Hill, Vancouver Island. (John Macoun.) Not before recorded from west of Winnipeg.

Lychis arfinis, Vahl.

Between Lake A thabasca and Chesterfield Inlet. Lat. 63 27', Long. $102^{\circ}, 1893$. (Jas. W. Tyrrell.) Cape Prince of Wales, Hudson Strait. (Dr. R. Bell.)

Lrchnis elata, Wats.

Our only specimens of this species are from Avalanche Mt., Selkirk Mts., B.C., alt. 7,000 ft. (Jas. M. Macoun.)

Lrchisis Taylore, Robinson, Proc. Amer. Acad. xxviii, 150.

Very slender 1 to $1 \frac{1}{2}$ feet high, puberulent, nearly smooth below, glandular above; stem erect, bearing 3 to 4 pairs of leaves and two or three long, slender, almost filiform 1 to 3 flowered branches; leaves thin, lance-linear, acute or 
attenuate both ways, finely ciliate, and pubescent upon the single nerve beneath, otherwise glabrate, 2 to $:-\frac{1}{2}$ inches in length; flowers terminal or subterminal on the branches; calyx orate, not much inflated, about 4 lines long, in anthesis but two lines in diameter with green nerves interlacing above; the teeth obtuse, with broad green membraneous ciliate margins; petals $1 \frac{1}{2}$ times the length of the calyx ; the blade obcortate, $1 \frac{1}{4}$ lines long, considerally broader than the slender auricled claw, appendages lance-oblong.

Peel's Ricer, Mackenzie River Delta, 1892. (Miss $\boldsymbol{E}$. Taylor.)

Lychnis triflora, R. Br. var. Dawsoni, Robinson, Proc. Amer. Acad. xxviii, 149.

Calyx with principal nerves double or triple, joined by interlacing veinlets; the intermediate nerves beneath the sinuses inconspicuous or wanting; petals very narrow; the blade oblong, bitid, hardly to be distinguished from the narrow elaw.

Gravel banks, Dease River, 100 miles north-east of Dease Lake. Lat. 59º, B.C., 1887. (Dr. G. M. Dauson.)

Cla ytonia Chamissonis, Esch.

Growing at high-water mark at Comox, Vancouver Island, 1893. (John Macoun, Herb. No. 29.)' These are our first authentic specimens of this species.

Cuatronia parviyolia, Moç.

Damp rocks, Sproat, Columbia River, B.C.; Griffin Lake, B.C.; Agassiz, B.C. (John Macoun.). Not before recorded between Selkirk Mts. and Vancouver Island.

Opdntia pragilis, Haw.

This plant, of which specimens were collected by Mr. A. C. Lawson in 1884 on islands in the Lake of the Woods, was found again in 1894 by Prof. A. P. Coleman on Red Pine

\footnotetext{
${ }^{1}$ Whenever herbarium numbers are giren, they are the numbers under which specimens have been distributed from the hebarium of the Geological Survey of Canada.
} 
Island, Rainy Lake, just within Canadian territory. It covered about a square rod of the eastern end of the island and grew half-buried in lichens. The Indians with Prof. Coleman did not know of its occurrence ulsowhere in that region.

Galium paldstre, L., var. minus, Lge.

A comparison of specimens collected by the Rev. A. Waghorne at Long Point, Labrador, with Greenland plants shows that what was at first considered a form of $G$. trifidum is in fact $G$. palustre, var. minus. New to Canada.

\section{Vernonia Noveboracensis, Willd.}

The plant from Eissex Centre, Ont., referred to this species, Macoun, Cat. Can. Plants, Vol. I., p. 206, proves to be $V$. altissima, Nutt. Specimens collected by Prof. Macoun in thickets at Pelee Island, Lake Erie, 1892, are V. Noveboracensis. We have seen no other Canadian specimens of this species.

Seriodarpus rigidus, Lindl.

In open thickets Mount Finlayson and Cedar Hill, near Victoria, V. I. and Nanaimo, Vancouver Island, 1887. Oak Bay, near Victoria, V. I., Herb. No. 451. (John Macoun.) Collected in 1887 but not recorded.

Heliopsis scabra, Dunal.

In thickets, Kicking Horse River, Rocky Mts., alt. 4,000 ft., 1890. (Jas. M. Macoun.) Woods, Revelstoke, Columbia River, B.C. (John Macoun.) Probably introduced from Manitoba by the C. P. Ry. Not before recolded west of Manitoba.

Madia glomerata, Hook.

Dry ground at Revelstoke, Columbia River, B.C.. 1890. (John Maccun.) Not before recorded west of Alberta.

Madia sativa, Molina, var. racemosa, (iray.

On dry banks, two miles from mouth of Kootanie River, B.C., 1890. (John Macoun.) Not before recorded from interior of British Columbia. 
Madia sativa, Mol., var. congesta, Gray.

Specimens (Herb. No. 466) collected by Prof. Macoun at Beacon Hill, Victoria, Vancouver Island, Aug. 7 th, 1893, and referred by him to this variety have been submitted to Dr. Robinson, who says, "a form showing characters of var. congesta (as to inflorescence) and var. racemosa (as to leaves and pubescence.)"

Hemizonelia Durandi, Gray.

Hillsides at Sproat, Columbia River, B.C., 1890. (John Macoun.) New to Canada.

Cotula aUatralis, Hook., f.

Ballast heaps at Nanaimo, Vancouver Island, 1893. (John Macoun, Herb. No. 47b.) New to Canada.

artemisia Richardsoniana, Bess. -

Mount Rapho, Lat. $56^{\circ} 13^{\prime}$, Long. $131^{\circ} 36^{\prime}$, alt. $3,800 \mathrm{ft}$., July, 1894. (Otto Klotz and H. W. E. Canavan, Herb. No. 4,191.)

Arnica latifolia, Bong. var. viscidula, Gray.

Woods at Roger's Pass, Selkirk Mts., B.C., alt. 4,500 ft., 1890. (John Macoun.) New to Canada.

Centaurga paniculata, $L$.

Dry waysides, Victoria, Vancouver Island. 1893. (John Macoun, Herb, No. 5̃2). New to Canada.

Cassiope Strlleriana, DC.

Mt. Rapho, Lat. $56^{\circ} 13^{\prime}$, Long. $131^{\circ} 36^{\prime}$. Alt, $3,800 \mathrm{ft}$. In flower July 10th, 1894. (Otto Klotz and H. W. E. Canavan, Herb. No. 4,195.) First Canadian record.

Primula cuneifolita, Ledeb.

Mt. Rapho, Lat. $56^{\circ} 13^{\prime}$, Long. $131^{\circ} 36^{\prime}$. Alt. $3.800 \mathrm{ft}$. In thower July 10th, 1894. (Otto Klotz and H.W. E. Canavan, Herb. 4,192.). New to Canada.

Collinsia verna, Nutt.

In woods near Plover Mills, Ont. In great abundance in 
one locality but not found elsewhere. Collested by $\mathbf{R}$. Elliott, May 22nd, 1894. New to Canada.

Pedicularis pedicellata, Bunge.

Mt. Head, Lat. $56^{\circ} 05^{\prime}$, Long. $131^{\circ} 08^{\prime}$. Alt. 4,200 ft. (Otto Klotz and H.W E. Canavan, Herb. No. 4,196.) Only authentic Canadian station.

Utriodlaria resupinata, B. D. Green.

Abundant on sand and mud both in shallow and gently flowing water. Phipps Lake, Long Reach, Kings Co., N.B., July 13th-20th, 1886. (C. H. Livingstone). Only Canadian station, though a plant believed to be this species was found by Prof. Macoun in Victoria Co., Ont., in 1868.

\section{AMARANTUS, Linn.}

Our herbarium specimens of this genus have been examined by Messrs. Uline and Bray who have either confirmed our determinations or made necessary corrections that are included in the following notes.

\section{A. Retroflexus, Linn.}

Specimens collected by Prof. Macoun at Agassiz, B.C., and referred here are intermediate between $A$. Powellii and A. retroflexus.

\section{A. HYBRIDUS, Linn.}

References under A. paniculatus and A. hypochondriacus, Macoun, Cat. Can. Plants, Vol. I, p. 396, are, so far as our hebarium specimens are concerned, A. hybridus.

A. Paniculatus, Linn.

Waste places, Sicamous, B.C., 1889. (John Macoun.) Our only specimens or this species.

A. gr motzans, Linn.

A. albus, L.; Macoun, Cat. Can. Plants, Vol. I, p. 397.

This species is well distributed throughout British North America. Specimens collected by the borders of saline ponds near Kamloops, B.C., by Jas. M. Macoun are near A. carneus, Greene. 


\section{A. BLitToides, Wat.}

Iondon, Ont. (Millman.) Port Colborne, Ont. (John Macoun.) Point Edward, St. Clair Rirer, Ont. (Jas. ML. Macoun.)

\section{POLTGONLM.}

All our herbarium specimens of this genus have been examined by Prof. John K. Small, who has made several important changes iu our determinations. He had not our herbarium sheets at the time his rerision of the Polygonacee was published so that the distribution of the Canadian species of Polygonum as giren below will greatly extend the range of many North American species. I follow Prof. Small's arrangement of the species throughout.

\section{(1.) P. Vivipandar, Linn.}

Throughout Canada. Our most northern specimens are from Lat. $64^{\circ} 26^{\prime}$, Long. $100^{\circ} 45^{\prime}$, 1893. (Jas. W. Tyrrell.) and Great Bear Lake River. Lat. 650, 1892. (Miss $E$. Taylor.)

(2.) P. Persicarta, Linn.

From Prince Edward Island to Vancourer Island. A bundant throughout the settled parts of Canada.

(3.) P. Carey, Olney.

Wet sandy banks, Noon Rirer, Muskoka. Ont., 1878. (Burgess.) The only Canadian station.

(4) P. hydropiperoides, Michx.

We have this species from but one locality, Bellerille, Ont. Many of the references given by Prof. Macoun (Cat. Can. Plants, Vol. I, p. 411), probably refer to other species. This plant is certainly not of as general distribution in Canada as is supposed, or our berbarium would contain specimens from more stations than one.

Of this species and rar. strigosum Prof. Small writes, " $P$. hydropiperoides, as well as the rar. strigosum, has an almost invariable character which it soems, has never been recorded. The stem or branches always produce, at the dis- 
tance of three-fourths of an inch or less above the angle of branching, a node with a leaf and ocrea, thus making an internode several times short $\%$ than normal length."

\section{Var. strigosum, Small.}

In ditches at Gatineau Point near Hull, Que. (Juhn Macoun.) In water near St. Patrick's Bridge, Ottawa, Ont. (Jas. M. Macoun, Herb. No. 1,503.)

(5.) P. Hydropipena, L.

From New Brunswick to Pacific Coast.

(6.) P. punctatum, Ell.

P. acre, Macoun, Cat. Can. Plants, Vol. I., p. 411.

Not rare in Eastern Canada. Agassiz, B. C., and Kamloops, B.C. (John Macoun.) Not before recorded west of Ontario.

(7.) P. Pennsyluanicum, $L$.

Common from Nova Scotia to Western Ontario.

(8.) P. mapathifoluim, L.

Common from the Atlantic to the Pacific. Prof. Small thinks this species has been introduced wherever found. While this may be so in most cases, we bave specimens from remote regions that are without doubt indigenous.

\section{Var. InOANUM, Koch.}

From Ontario to the Pacific.

(9.) P. Амтніві Uм, L.

Tadousac, Que. (Northrop.) Wingham, Ont. (J. A. Morton.) Hastings Co., Ont.; Long Portage, Nipigon River, Ont. ; Tail Creek, N.W.T. ; neal' Victoria, Vancouver Island. (John Macoun.) Near Pincher Creek, Alberta. (Dr. G. M. Davison.)

(10.) P. kmersum, (Michx.) Britt.

Most of the references under $P$. Muhlenbergii, Macoun, Cat. Can. Plants, Vol. I., p. 410, and Vol. II., p. 353, go here. Our herbarium specimens are from Wingham, Ont. 
(J. A. Morton.) Leamy's Lake, Hull, Que.; Tail Creek, N.W.T. (John Maroun.) Indian Head, Assa. (W. Spreadborough.) Short Creek, Souris River, Man.; Belly River, Alberta. (Dr. G. M. Dauson.) "Arctic North America," no locality. (Dr. Richardson.)

(11.) P. Hartwrighti, Gray,

Salt Lake, Anticosti, Que.; Elziver, Hastings Co., Ont.; Vermillion Lakes, near Banfi, Rocky Mts. (Herb. No. 1,481.) ; Revelstoke, B.C.; Kamloops, B.C. (John Macoun.) Near York Factory, Hudson Bay. (Dr. R. Bell.) London, Ont. (Burgess.) Muskeg Island, Lake Winnipeg. (Jas. M. Macoun.)

(12.) P. Orientale, L.

Ottawa, Ont. (Dr. A. R. C. Selwyn.) London, Ont. (Burgess.)

(13.) P. alpinum, All.

Peel River, Mackenzie River Delta, 1892, (Miss E. Taylor). The references under $P$. polymorphum, Macoun, Cat. Can. Plants, Vol. I., p. 412, probably all go with this species or its var. lapathofolium.

(14.) P. afioulare, L.

From Ontario to Vancouver Island.

VAR. BorEalis, Lange.

Specimens collected on the East Main River, Hudson Bay, by A. H. D. Ross, in 1892 , when compared with specimens from Greenland seem certainly referable here.

(15.) P. Littorale, Link.

P. erectum, Macoun, Cat. Can. Plants, Vol. 1., p. 407 in part.

Thunder Bay, Lake Superior. (N. L. Britton.) Castle Mountain, Rocky Mts.; Banff, Rocky Mts., Herb. No. 1,487; near Devil's Lake, Rocky .Mts., Herb. No. 1,486. (John Macoun.) Walsh, Assa. (J.M. Macoun.) 
(16) P. Rayr, Bab.

P. maritimum, Macoun, Cat. Can. Plants, Vol. I., p. 408.

Turner's IIead, Labrador. (Rev. A. Waghorne.) Brackley Point, P.E.I.; Jupiter River, Anticosti, Que.; Qualicum and Point Holmes, Comox, Vancouver Island. Herb. No. 1505. (John Macoun.) Hass River, N.B. (Fowler.) We do not believe, that this plant, "wherever found," in Canada, has been introduced. Prof. Small found among our specimens no representatives of $P$. maritimum, and as our specimens of $P$. Rayi are from widely separated and remote localities on the Atlantic and Pacific coasts, it seems probable that we have but one species in Canada, and that it is, at least in part, indigenous.

(17.) P. Paronyohia, C. \& S.

Beacon Hill, Vancouver Island. (John Macoun. C. F. Newcombe.)

(18.) P. ERectum, L.

Our only specimens of this species are from Winnipeg, Man.; Banff, Rocky Mts. Herb. No. 1,485. (John Macoun.)

Other specimens referred here by Prof. Macoun, Cat. Can. Plants, Vol. I., p. 407, are now included under other species.

(19.) P. вамовissimom, Michx.

Petitcodiac, N,B. (J. Britain.) Rat Creek, Man.; IIand Hills, N.W.T.; South of Battleford, N.W.T. (John Macoun.)

(20.) P. Douglasir, Greene.

P. tenue, Macoun, Cat. Can. Plants, Vol. I, p. 408.

Not rare from Ontario to British Columbia. We have apparently no $P$. tenue in Canada.

Prof. Small says of this species, " $P$. Douglasii can be distinguished from its relative $P$. tenue at a glance, and is beautiful'y distinct, as Prof. Greene has pointed uut, by its one-ribbed leaf in place of the three-ribbed of $P$. tenue, and the much longer, narrower and pedicelled, drooping fruit, instead of the short, thick, sessile, erect fruit of that plant." 
(⒈) P. austinz, Greene.

South Kootanie Pass, Rocky IIts., 1883. (Dr. G. M. Dauson.) Near the glacier at the head of Lake Lonise,

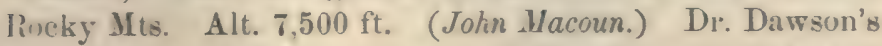
- precimens were collected a year before Mrs. Austin's, and were named $P$. tenue, Michx., var. latifolium, Eng., by Prof. Macoun.

(22.) P. spergulari.eforme, Meisn.

P. coarctatum, Dougl.

From the Columbia River at Sproat, B.C., to Vancouver Island.

(23). P. Minimom, Wats.

South Kootanie Pass, Rocky Mts. (Dr. (r. M. Daxeson.) Roger's Pass, Selkirk MIs., B.C.; Griftin's Lake, B.C. (John Macoun.)

(24.) P. INTermedum, Nutt.

Summit of Mrt. Mark, Vaneourer Island. (John Macoun.) (25.) P. imbricatum, Nutt.

Hand Hills and C'ypress Hills, Alberta. (John Macoun.)

(26.) P. Convolvelus, L.

Common in fields and waste places from the Atlantic to the Pacific.

(27.) P. scandens, L.

$P$. dumetorum, L., var. scandens, Gray.

From Nora Scotia to the Cypress Hills, Alberta.

(28.) P. orinode, Michx.

In pine woods and thickets fiom Nova Sectia to the Peace River, Athabasea.

(29.) P. sagitratum, $\mathrm{L}$.

From Prince Edward Island to the Saskatchewan.

(30.) P. ARIFOLIUM.

From Nova Scotia to Ontario. 
(31.) P. Virginiandm, Linn.

All our specimens of this speries were collected in Ontario. Reported from Nova Scotia and Quebec.

Polygonella articulata, Meisn.

Polygonum articulatum, Willd; Macoun, Cat. Can. Plants Vol. I., p. 409.

Sand dunes, Point Aux Pins, Lake Superior, 1869. (John Macoun.) Specimens collected by Di: Richardson, and labelled "Aretic North America," are probably from the same locality. 




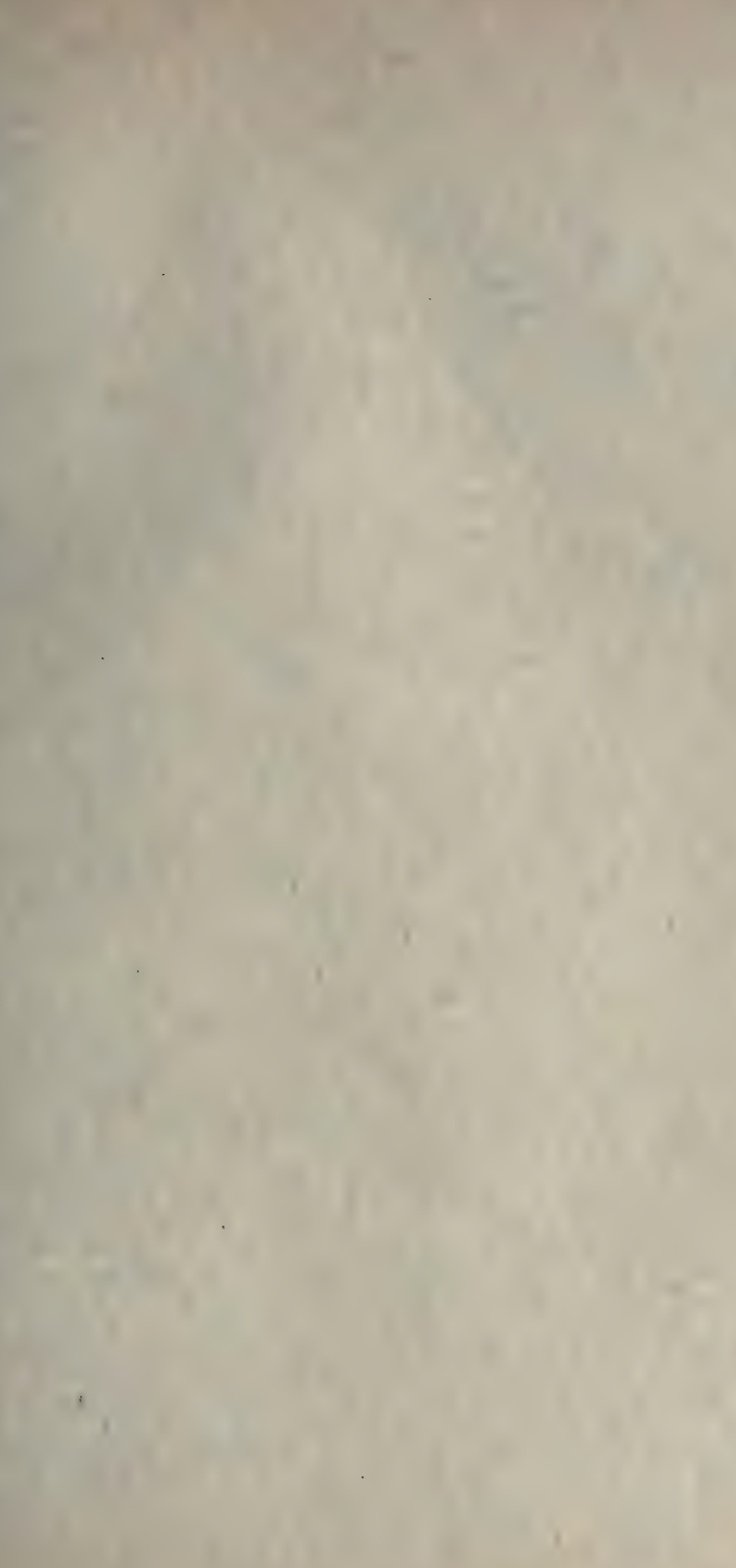





\section{Contributions from the Herbarium of the}

Geological Survey of Canada.

(By Permission of the Director.)

By Junras M. Macors,

Cherator of the Herbarium.

$\because \because-$

$\therefore$ TH

$-$

Reprinted from the Caradian Recond of Science, January, 1895. 

"Reprinted from the Canadian Record of Science, January, 1895."

\section{Contributions to Canadian Botany.}

By James M. Macoun.

$\mathrm{V}$.

Thalictrey rexclosem, Trelease.

In thickets, Seven Persons' Coulee, Medicine Hat, Assa.; Crane Lake, Assa.; Cypress Hills, Assa., 189t. (John Mucoun, Herb Nos. 2952, 2953, 2954. ${ }^{1}$ ) Our only records between Lake Manitoba and the Rocky Mountains. ${ }^{2}$

RaNunCULUS abortivUs, Linn.

Lake Petitsikapau, Hamilton River, Labrador, 1894. (A. P. Low, Herb No. 4331.) Most northern record for Eastern Canada.

Ravunculus Hispidus, Michx.

Our only specimens of this plant are from Wesley Park, Niagara, Ont. (John Macoun.)

Ranunculus Cooleye, V. \& R.

Mount Rapho, Lat. 56 $6^{\circ} 13^{\prime}$, Long. $131^{\circ} 46^{\prime}$. Alt. 3,800 ft. July, 1894. (Otto Klotz and H.W. E. Canavan.) Only Canadian record. First collected near Juneau, Alaska, by Miss Grace Cooley, in 1891.

ACt.fa SPICATA, Linn, var. RCBRA, Ait.

Lake Michikamau, Labrador, 1894. (A. P. Lou: Herl, No. 4331.) Northern limit in Eastern Canada.

NYMPh

New stations for this rare plant are Loon Lake, C. P. Ry. east of Port Arthur, Ont., and Petobi Brook, Gull Bay, Lake Nepigon, Ont., 1894. ( $W m$. MeInnis.)

1 Whenever herbariun numbers are given, they are the numbers under which specimens have been distributed from the her barium of the Genlugical Survey of Canada.

2 The geographical limits given in these papers refer to Canada only. 
Barbarea vulgaris, $R$. Br.

Lake Petitsikapau, Hamilton River, Labrador, 1894. (A. P. Low. Herb No. 4340.) Not before recorded from Labrador.

Viola Paldstris, Linn.

Ashuanipi branch of Hamilton River, Labrador. (A. P. Low. Herb. No. 4343.) Not before recorded from Labrador.

Cerastium viscosum, Linn.

C. glomeratum, Thuill.

Burrard Inlet, B.C., and many places in vicinity of Victoria, Vancouver Island. (John Macoun.) Not found anywhere in Eastern Canada, all references but one, under C. viscosum, in Prof. Macoun's Catalogue of Canadian Plants going with $C$. vulgatum.

Cerastum vulgatum, Linn.

C. viscosum, Macoun, Cat. Can. Plants, Vol. 1., page 77, in part.

Widely distributed throughout Eastern Canada. Revelstoke, B.C. (John Macoun.) North of Finlayson Lake, B.C., Lat. $59^{\circ}$. (Dr. G. M. Dawson.)

Cerastium nutans, Raf.

Sproat, Columbia River, B.C., 1890. (John Macoun.) Cherry Creek, east of Lake Okanagan, B.C. (Jas. McEvoy.) Only British Culumbia stations.

Cerastium arvense, Linn,, var. oblongifolium, H. \& B.

C. oblongifolium, Torrey; Macoun, Cat. Can. Plants, Vol. I., p. 77.

A narrow-leaved form of this variety was collected at Truro, N.S., by Prof. Macoun, July, 1883. Only station east of Ontario. . 
Cerasticm alpincm, Linn.

Arctic America, from Labrador to Alaska. References under var. Fischerianum, Macoun Cat. Can. Plants, Vol. I., p. 498, go here. This variety is confined to the Pacific Coast.

Cerastium atpinum, Linn., var. Berringlancm, Regel.

Aretic America, and on many of the higher Rocky Mountains.

Stelilaria aquatica, Scopoli.

The only stations for this species in Canada are Stratford, Ont. (Burgess). Roadsides and ballast heaps, Nanaimo, Vancouver Island, 1893. (John Macoun.)

Stetituata Nitens, Nutt.

Dry slopes, Agassiz, B.C.; Kamloops, B.C., 1889. (John Macoun.) Not before collected on mainland of British Columbia.

Stellatia loNgipes, Goldie, var. LÆTA, Wats.

S. longipes, Goldie, var. Eduardsii, T. \& G.; Macoun, Cat. Can. Plants, Vol. I., pp. 76 and 498, in part.

From New Brunswick and Labrador to British Columbia and throughout Aretic America. Our herbarium specimens are from Petitcodiac, N.B. (Brittain.) Pack's Harbor, Labrador. (Rev. A. Waghorne.) Ford's Harbor, Labrador; Digge's Island, Mansfield Island and Nottingham Island, Hudson Bay. (Dr. R. Bell.) Lat. 62 03', Long.

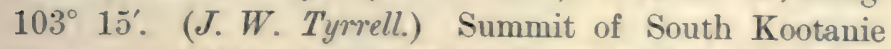
Pass, Rocky Mts. (Dr. G. M. Dau'son.) Saddle Mountain, Banff, Rocky Mts.; Kicking Horse Lake, Rocky Mts., alt. 8,000 feet : Stewart's Lake Mountain, B.C. (John Macoun.) Mountains at Roger's Pass, Selkirk Mts., alt. 7,500 ft.; Mount Queest, Shuswap Lake, B.C., alt. $6,500 \mathrm{ft}$. (Jas. M. Macoun.) 
Stellaria LongIPES, Goldie, var. EDWARDsII, Wats.

From Labrador to British Columbia and northward to the Aretic regions. Our only specimens of this variety are from Quesnelle, B.C. (John Macoun.)

Stellaria graminea, Linn.

In sandy woods, Fort George, Hudson Bay. (Jas. M. Macoun.) Probably indigenous. Only record north of Nova Scotia.

\section{Stellatia dliginosa, Murr.}

This species is confined to the Atlantic slope and is not of as wide distribution as is given it by Prof. Macoun, Cat. Can. Plants, Vol. I., pp. 75 and 497. Our specimens are from Hunter's River, Prince Edward Island, and Point Pleasant, near Halifax, N.S. (John Macoun.)

Stellaria borealis, Bigel. var. corolitina, Fenzl.

S. borealis, Bigel. var. alpestris, Gray; Macoun Cat. Can. Plants, Vol. I., p. 74.

Dr. Robinson places the eastern limit of this variety at Lake Superior. We have, however, specimens from Brackley Point, Prince Edward Island. (John Macoun.) Lake Mistassini, N.E.Ter. (Jas. M. Macoun.) The only western reference for this variety given by Prof. Macoun is Yale, B.C. Later collections show it to be a common plant in many parts of the Northwest and British Columbia, and especially abundant wherever collections have been made on Vancouver Island.

Stellaria crassifolia, Ehrh.

S. gracilis, Rich., Macoun Cat. Can. Plants, Vol. I, p. 75.

Pelly Banks, Lat. 61 ${ }^{\circ}$, Yukon District. (Dr. G. M. Dawson.) Not before recorled west of the prairie region. 
Stellaria hesifesa, Rottb., var. oblongifolia, Fenzl.

Blinkinsop Bay, B.C., 1885. (Dr. G. M. Darson.) Not before recorded from Canada. Referred to $S$. uliginosa, by Prof. Macoun, Cat. Can. Plants, Vol. I, p. 497.

Stellaria obtusa, Engelm.

Near MacLeod's Lake, B.C. (John Macoun.) South Kootanie Pass, Rocky Mts. (Dr. G. M. Daurson.) The only Canadian stations.

Arevaria ciliata, Linn. var. himiftsa, Hornem.

Cerastium trigynum, Macoun Cat. Can. Plants, Vol. I., p. 498 in part.

Stellaria humifusa, Macoun Cat. Can. Plants, Vol. I., p. 498 in part.

Mount Allert, Gaspé, Que. (Allen. Porter.) Lake Mistassini, X.E.Ter. (Jas. M. Macoun.) Specimens collected at Kicking Horse Lake, Rucky Mts., and on the summit of Mount Aylmer, Banff, Rocky Mts., alt. 8,300 feet, have been doubtfully referred here by Dr. Robinson.

Arevaria congesta, Nutt., var. scbcongesta, Wats.

Gravelly banks, Lewis River, Lat. 62 ${ }^{\circ}$, Yukon District. (Dr. G. M. Dauson.) Not before recorded west of Alberta.

Arenaria Sajanensis, Willd.

A. aretice, Macoun, Cat. Can. Plants, Vol. I., p. 71.

A. biflora, Wats., var. obtusa, Wats.; Macoun, Cat. Can. Plants, Vol. I., pp. 71 and 496.

A. verna, Macoun, Cat. Can. Plants, Vol. I., p. 496 in part.

A. verna, var. rubella, Macoun, Cat. Can. Plants, Vol. I., p. 72 in part.

Mount Albert, Gaspé, Que. (Porter. Maconn.) These specimens were referred to $A$. arctica and $A$. cerna, var. rubella, by Prof. Macoun. Cape Chudleigh, Hudson 
Strait. (Dr. R. Bell.) Referred to A. verna by Prof. Macoun. Common on mountains throughout British Columbia.

According to Dr. Robinson A. arctica, Stev., is not found in British America.

Arenaria stricta, Fenzl.

A. Michauxii, Hook., Macoun, Cat. Can. Plants., Vol. I., pp. 72 and 496 .

Dr. Robinson makes Minnesota the western limit of this species. It is not uncommon in the Rocky Mts. near the line of the Canadian Pacific Railway, our specimens being from several stations in and near the National Park at Banff.

SAgina occidentalis, Wats.

Gordon Head and Cedar Hill, Vancouver Island. (John Macoun.)

Sagina Linnæa, Presl.

Mount Aylmer, Rocky Mts., alt. 8,300 ft.; Kicking Horse Lake, Rocky Mts., alt. 8,000 ft.; Roger's Pass, B.C.; between Sproat and Nelson, B.C.; Burrard Inlet, B.C.; Nanaimo, Vancouver Island. Herb No. 19. (John Macoun.) Summit of South Kootanie Pass, Rocky Mts.; Queen Charlotte Islands. (Dr. G. M. Dawson.) Mountains north of Griffin Lake, B.C.; Mount Queest, Shuswap Lake, B.C. (Jas. M. Macoun.)

\section{S. CRASSICAULIS, Wats.}

Gordon Head, Esquimault, and Goldstream, nearVictoria, Vancouver Island; Comox and Nanaimo, Vancouver Island. (John Macoun.)

Note.-The references under these three species are in part in addition to those given by Prof. Macoun under S. occidentalis and S. Linnoca, Cat. Can. Plants, Vol. I., 
pp. 79 and 499 , and the arrangement now given is intended to take the place of that in the catalogue.

Hypericum CaNadense, Linn.

In sandy soil at Kamloops, B.C.; wet ground, Sproat Lake, Vancouver Island. (John Macoun.) Not before recorded west of Alberta.

Malva Parviflora, Linn.

M. borealis, Macoun, Cat. Vol. II., p. 313.

Specimens of this plant were collected on ballast heaps at Nanaimo, Vancouver Island in 1887, by Prof. Macoum, and called $M$. borealis. It was again found by him at the same place in 1893 (Herb. No. 46) and correctly determined by Prof. Greene.

Malva rotundifolia, Linn.

Waste places at Beacon Hill, Vancouver Island, 1893. (John Macoun, Herb. No. 47.)

Sidalcea malveflora, Gray.

Common at Revelstoke. (John Macoun.) Not before recorded from interior of British Columbia.

Malvastrum Coccineum, Nutt.

On dry soil, 7 miles from the mouth of Deadman River, near Kamloops Lake, B.C. (Jas. McEvoy.) Not before recorded west of the prairie region.

Linum Lewisir, Pursh.

A white-flowered procumbent form of this plant was collected in Lat. $56^{\circ}$ on the west side of Hudson Bay, by Jas. M. Macoun, in 1886. No plants with blue flowers were seen.

Grraniom erianthum, DC.

Alice Arm, Observatory Inlet, B.C,. July 7th, 1893. (Jas. McEvoy. Herb. No. 60.) Southern limit. 
Geranium pusillum, Linn.

Agassiz, B.C. (Macoun.) We have no other record of this plant between Ontario and the Pacific Coast.

Geranium Richardononi, Fisch. \& Mey.

In open woods at Botanie, near Spence's Bridge, B.C., Alt. 3,500 ft. (Jas. M. Macoun.) - Not before recorded west of the Rocky Mountains.

Limnathes Macouni, Trelease.

First collected by Prof. Macoun at Victoria, Vancouver Island, in 1875. Found again by him in May, 1893, in abundance in ditches and swampy places near Victoria. No other stations for this speeies are known.

Flakrkea proserpinacoides, Willd.

Wet places near springs, Casselman, Ont., in flower, May 14th, 1891. (John Macoun.) Only record from Eastern Ontario.

OXALIS CORNICULATA, Linn.

On ballast heaps, Nanaimo, Vancouver Island, 1893. (Macoun, Herb. No. 54.) Only record from British Columbia.

Oxalis corniculata, L., var. stricta, Sav.

In dampish spots near Indian Head, Assa., 1892. (W. Spreadborough.) Not before recorded west of the Red River.

IMPATIENS PALLIDA, Nutt.

Anstey Creek, Shuswap Lake, B.C., 1889. (Jas. M. Macoun.) Agassiz, B.C. (John Macoun.)

Ceanothus sanguineus, Pursh.

Sicamous and Revelstoke, B.C., 1889. (John Macoun.) Eastern limit. 
Rhannus Purshiana, DC.

In woods at Revelstoke, Columbia River, B.C. (John Macoun.) Eastern limit.

\section{ACRR SACCHARUM, Marshall.}

A. saccharinum, Wang., Macoun Cat. Can. Plants, Vol. I, p. 99 in part.

A. saccharinum, Wang., var. nigrum, T. \& G. : Maconn Cat. Can. Plants, Vol. I., p. 99.

Bark gray; internodes mostly slender and elongated, commonly glossy and reddish.: buds gray, conical, slender and acute : petioles, little dilated at base, not concealing the mature luds, without stipules; leares, thin, typically large (usually 4 to 7 inches broad), flat, dull, usually light green above, the lower surface grayish, glabrous to pubescent, or exceptionally quite hirsute when young, isodiametric, truncate at base to slightly cordate with an open sinus, or broally cuneate, rather deeply 5-lobed, except for some smaller 3-lobed leaves near the ends of the l,ranches, with typically narrow sinuses, the three larger lobes with parallel sides or dilated upwardly and each with a slender apical acumination often sinuously bilentate on the siles, and two similar lateral acuminations, or the lateral lobes merely sinuate on the upper margin, the smaller outermost lobes mostly sinuously 1 to 2 toothed on the lower margin ; fruit, large (6 to $10 \mathrm{~mm}$.), the outer lines of the large wings ( 8 to $12 \times 16$ to $28 \mathrm{~mm}$.), nearly parallel or spreading to something less than a right angle.

From Nova Scotia to Lake Superior.

ACER SACCharty, var. BARbatum (Michx.), Trelease.

A. saccharinum, Wang.; Macoun, Cat. Can. Plants, Vol. I., p. 99, in part.

Bark, gray to almost black; internodes often shorter and stouter, commonly dull but redelish; buds gray, pubescent or dark, conical oroid, often obtuse; petioles as 
in the last and without stipules; leaves firm, of medium size (usually about 4 in. broad), flat, somewhat glossy and of various shades of green above, pale or glaucous and downy to glabrous beneath, mostly broader than long, cordate with shallow open basal sinus to truncate, 3-lobed, with very open round sinuses (the upper margin of the lateral lobes often spreading nearly in a straight line), the lobes sinuously narrowed from the base to a single acumination, or the median line sometimes dilated by a pair of blunt shoulders, one or two similar dilations also on the lower margin of each lateral lobe, and exceptionally developed into short complementary lobes; fruit as in the last.

This tree ranges in the United States from Connecticut to Missouri and Michigan, and probably grows in many parts of Eastern Canada. Specimens intermediate between this variety and $A$. saccharum from Belleville, Ont. (John Macoun), and Niagara Falls, Ont. (Jos. Schrenk) have been referred here by Dr. Trelease. These are the only Canadian specimens of this variety in our herbarium.

\section{ACER saccharum, var. Nigrum (Michx. f.), Britton.}

Bark, nearly black; internodes, stout, sometimes short, dull, buff; buds, dark, ovoid, often obtuse; petioles dilated at base so as, usually, to cover the buds, with adnate triangular or oblong foliaceous stipules; leaves soft but of heavy texture, large (usually 5 to 6 in. broad), with drooping sides, dull and dark green above, clear green and usually persistently downy below, isodiametric, the larger deeply cordate with often closed sinus, 3 to 5 -lobed, with shallow broad sinuses from which the lobes are undulately narrowed to an acute or acuminate point, rarely with short lateral acuminations; fruit, as in the last.

Ranges in the United States from New York to Missouri and Michigan, but not known certainly to occur in Canada, though frequently reported. 
Note-These descriptions of the several forms of Sugar Maples have been reprinted from Dr. Trelease's Monograph in 5th Annual Report of Missouri Botanical Garden, and space is given to them as they change very materially our knowledge of these trees, and by printing the descriptions in full it is hoped that Canadian botanists will be led to carefully observe the sugar maples in their vicinity.

Rhus Glabra, Iinn.

R. glabra, L., var. occidentalis, Torrey: Macoun, Cat. Can. Plants, Vol. I, p. 505.

Deer Park, Lower Arrow Lake, B.C.; Kamloops, B.C., and Spence's Bridge, B.C. (John Macoun.) Only references west of Ontario.

Rhus copallina, Linn.

Rocky hillsides at Lansdowne, Ont. (Rev. Chas. Young.) Very rare in Canada.

\section{LUPINUS ARCTICUS, Wats.}

Additional stations for this species are Upper Liard River, Lat. $60^{\circ}$, Yukon District: forks of Stikine River, B.C. (Dr. G. M. Dauson.) Fifty miles below Lower Ramparts, Mackenzie River. (R. S. McConnel.) Fort Good Hope, Mackenzie River. (Miss E. Taylor.) Specimens collected at Medicine Hat in flower, May 31st, 1894, have been referred here by Dr. Robinson. (John Macoun, Herb. No. 4190.)

Saxifraga Tolmei, Torr. \& Gray.

On Mount Head, alt. 4,200 ft., Lat. $56^{\circ} \quad 05^{\prime}$, Long. 131 ${ }^{\circ} 09^{\prime}, 1894$. (Otto Klotz and H. W. E. Canavan, Herb. No. 4197.) First authentic record for Canada.

\section{Thu, Ra SiMPlex, NuTT.}

In mud in a mill pond at Mount Stewart, Prince Edward Island, 1888. (John Macoun.) New to Canada. 
(Enothera micrantha, Horn.

On ballast heaps at Nanaimo, Vancouver Island, 1893. (John Macoun, Herb. No. 249.) Introduced from the south. New to Canada.

Phacelia hispida, Gray.

On ballast heaps, Nanaimo, Vancouver Island, 1893. (John Macoun, Herb. No. 654.) Introduced from the south. New to Canada.

Krynitzia ambigda, Gray.

On ballast heaps at Nanaimo, Vancouver Island, 1893. (John Macoun, Herb. No. 672.) Introduced from California. New to Canada.

Amsinckia barbata, Greene, Erythræa, Vol. II., No. 12. p. 192.

Stout and coarse, erect or decumbent, the branches loosely floriferous throughout, all excepting the uppermost pedicels subtended each by a broad ovate-lanceolate amplexicaul foliaceous bract; sepals 4 . or 5 lines long, nearly linear, without rufous or fulvous pubescence, but densely white-hirsute along the margins, sparsely hispid with whitish bristles an the back; corolla small; nutlets ovate-acuminate, closely muricate-tuberculate, without transverse rugosities, but with an elevated and toothed dorsal ridge.

Collected at Cameron Lake, Vancouver Island, 15th July, 1887, by John Macoun. Type specimen in the herbarium of the British Museum. Distributed by Prof. Macoun as Amsinckia lycopsoides.

ZaNnichelia PALUSTRIS, Linn.

In the Spullamacheen River at Enderby, B.C., 1889. (Jas. M. Macoun.) Not before recorded west of the Saskatchewan. 
Natas Flexilts, Rostk. \& Sehmidt.

Enderby, B.C., 1889. (Jas. M. Macoun.) Kamloops, B.C. (Jas. McEroy.) Revelstoke, B.C. (John Macoun.) Not before recorded from interior of British Columbia.

Zostera latifolia, Morong.

Z. marina, Macoun, Cat. Can. Plants, Vol. II., p. 90, in part.

Burrard Inlet, B.C.; Esquimalt, Vancouver Island, (John Macoun.)

Phyllospadix Torreyi, Wats.

Amongst rocks below half-tide, Stubb's Island, west coast of Vancouver Island, 1893. (W. Spreadborough, Herb. No. 4502.) New to Canada.

Beckmaxyia eruc.formis, Host, var. Uyiflora, Scrib.

Sea's Farm, near Victoria, Vancouver Island, 189:3. (John Macoun.) Not before recorded west of the Rocky Mountains. Perhaps introduced. 



\section{-}

. 





\title{
Contributions from the Herbarium of the
} Geological Survey of Canada.

(By Permlssion of the Director.)

\author{
By James M. Macodx, \\ Curritor of the Herbarium.
}

VI.

Reprinted from the Cunalian Record of Science, April, 1595. 

"Reprinted from the Canadian Record of Science, April, 1895."

\section{Contributions to Canadian Botany.}

By James M. Macoun.

VI.

Caltha leptosepata, DC.

Mount Queest, Shuswap Lake, B.C. (Jas. M. Macoun.) Mountains at Roger's Pass, B.C.; mountains north of Griffin Lake, B.C. ; Mount Arrowsmith, Vancouver Island, alt. 5,500 feet. (John Macoun.) Not before recorded from Vancouver Island.

Draba alpina, L, var. Glaclalis, Dickie.

Cornwall Hills, west of Ashcroft, Thompson River, B.C., alt. 6,600 feet. (Jas. McEvoy, Herb. No. 5098.*) Not recorded west of Rocky Mountains. *

LUPiNus LAXIFLORUS, Dougl.

Deer Park, Lower Arrow Lake, B.C.; Sproat, Columbia River, B.C., 1890. (John Macoun.)

\section{Lupinus Nootkatensis, Don.}

Revelstoke and Sproat, Columbia River, B.C. ; mountains north of Griffin Lake, B.C. (John Macoun.) Mountains south of Tulameen River, B.C. (Dr.G.M.Dawson.) North Thompson River B.C.; Mt. Queest, Shuswap Lake, B.C. ; Toad Mountain, Kootaine Lake, B.C. (Jas. M. Maconn.) East of Stump Lake, B.C. (Jas. McEvoy.) Cariboo Mountains, B.C. (Amos Bowman.) Not before recorded from interior of British Columbia. The above references include forms which may be ultimately separated into varieties.

* Whenever herbarium numbers are given, they are the numbers under which speclmens have been distributed from the herbarium of the Geological Survey of Canada.

*2 The geographical limits given in this paper refer to Canada only. 
Melilotus officinalis, Willd.

Along the streets of Banff, Rocky Mountains, and in gardens at Spence's Bridge, B.C. (John Macoun.) Not before recorded west of Ontario, though probably of general distribution throughout the settled parts of Canada.

Medicago denticulata, Willd.

On ballast at Nanaimo, Vancouver Island. (John Macoun, Herb. No. 125.) The var. apiculata, Willd, was collected by Prof. Macoun at the same place in 1887.

Medicago sativa, L.

Ballast heaps at Nanaimo, Vancouver Island. (John Macoun.) Not before recorded west of Ontario.

Trifolium HYBRIDUM, L.

Medicine Hat, Assa.; Banff, Rocky Mountains; Roger's Pass, Selkirk Mountains; Nanaimo, Vancouver Island. (John Macoun.)

Trifolidm PAdCIFlorum, Nutt.

On gravel, Penticton, Lake Okonagan, B.C., 1889. (John Macoun.) Only record from interior of British Columbia.

OXYTROPIS CAMPESTRIS, DC.

Dry banks of the Upper Liard River, Lat. $60^{\circ}$, Yukon District, 1887. (Dr. G. M. Dawson.) Fort Severn, Hudson Bay, 1886. (Jas. M. Macoun.)

OxyTropis viscida, Nutt.

Dry banks, Dease Lake, Lat. $58^{\circ} 30^{\prime}$, B.C., 1887. (Dr. G. M. Dawson.)

Vicra Americana, Muhl, var. Linearis, Wat.

In thickets at Nanaimo, Vancouver Island, 1887. (John Macoun.) Not before recorded west of Rocky Mountains. 
Victa Cracca, L.

Meadows at Spence's Bridge, B.C., 1889. (John Macoun.) Not before recorded west of Ontario.

LATHYRUS OCHROLEUCUS, Hook.

Thickets at Agassiz, B.C., 75 miles from coast. (John Macoun.) Western limit in Canada.

LATHYRUS PALUSTER, I.

Thickets at Barclay Sound, Vancouver Island. (John. Macoun.) Not before recorded from Tancouver Island.

Prexcs spinosa, L., var. nstitia, Gray.

In thickets, Pelee Island, Lake Erie, 1892. (John Macoun.) Not before recorded from Canada. Naturalized.

Pronus Pennsyluanica, L.

Forming thickets throughout Iabrador north to Lat. 54. (A. P. Lowo.)

Spiraia Betulifolit, Pallas.

Peel's River, Mackenzie Piver Delta, 1892. (Miss $E$. Taylor.) Northern limit in Canada.

SpIr.ea discolor, Pursh., var. ARI.efolia, Wat.

Woods at Sicamous, B.C., and Sproat, Columbia River, B.C. (John Mucoun.) Not before recorded from interior of British Columbia.

Spirea Dotglasir, Hook, var. yobleara, Wat.

Thickets at Revelstoke, B.C., 1890. (John Mucoun.) Not before recorded from Canada.

SpIrafa pectinata, T. \& G.

Peel's River, Mackenzie River, 1889. (R. McConnell.) Northern limit in Canada. 
Rubus strigosus, Michx.

In river valleys north to Lat. $57^{\circ}$, Labrador. (A. $P$. Low.) Lat. $60^{\circ} 17^{\prime}$, Long. $103^{\circ} 07^{\prime}$. (Jas. W. Tyrrell.) Peel's River, Mackenzie River Delta. (Miss E. Taylor.)

Rubus Leucodermis, Dougl.

In thickets, Deer Park, Lower Arrow Lake, B.C., 1890. (John Macoun.) Eastern limit.

Geum calthifolium, Menzies.

Lincoln Mt., Observatory Inlet, B.C., 1893. (Jas. McEvoy.) Not found in Canada since Menzies' time.

Geum macrophyluUm, Willd.

Cedar Hill and Comox, Vancouver Island. (John Macoun.) Not before recorded from Vancouver Island.

Geum strictum, Ait.

Fort Simpson, Lat. $62^{\circ}$, Mackenzie River. (Miss $E$. Taylor.) Common in the vicinity of Victoria, Vancouver Island. (John Macoun.)

Potentilla glandulosa, Lindl.

Eagle Pass, B.C.; Nanaimo and Mount Benson, Vancouver Island. (John Macoun.) Not before recorded from Vancouver Island.

Potentilla Rivalis, Nutt., var. Millegrana, Wat.

Borders of irrigation ditches, Spence's Bridge, B.C., 1889. (John Macoun.) Perhaps introduced. Not before recorded west of Rocky Mountains.

Sibbaldia procumbens, Linn.

Mount Queest, Shuswap Lake, B.C. (Jas. M. Macoun.) Mountains at Griffin Lake, B.C., alt. 6,000 feet; Mount Arrowsmith, Vancouver Island, alt. 5,600 feet. (John Macoun.) Not before recorded from Vancouver Island. 
Agrimonia Eupatoria, Linn.

Moist thickets, mouth of Kootaine River, B.C. (Dr. Geo. M. Dawson.) Revelstoke and Agassiz, B.C. (John Macoun.) Not before recorded west of the Rocky Mountains.

Potericir Canadexse, Benth \& Hook.

Common in river valleys in Labrador, north to Lat. $58^{\circ}$. (A. P. Low.)

Potertum Saygutsorba, Linn.

In fields at Spence's Bridge, B.C. (John Macoun.) Not recorded west of Ontario. This reference was placed by mistake under $P$. annuum by Prof. Macoun. (Cat. Can. Plants, vol. II, p. 319.)

Pirus Americana, DC.

Not rare in interior of Labrador north to Lat. $54^{\text {. }}$. (A. P. Low.)

Saxifraga nivatis, Linn.

Borders of coulees, Cypress Hills, Assa., 1894. (John Macoun, Herb. No. 4921.) Not before recorded between Hudson Bay and the Rocky Mountains.

Hecchera cylisdrica, Dongl., var. glabelda, Wheelock. H. Hallii, Macoun, Cat. Can. Plants, Vol. I., p. 158, in part.

Summit of South Kootanie Pass, Rocky Mountains. (Dr. G. M. Dawson.)

Hetchera CYlindrica, Dougl., var. OTALifolia, Wheelock. H. Hallii, Macoun, Cat. Can. Plants, Vol. I., p. 158, in part.

H. cylindrica, Dougl., var. alpina, Macoun, Cat. Can. Plants, Vol. I., p. 526. 
Crow Nest Pass, Rocky Mountains; South of Kamloops, B.C. (Dr. G.M. Dawson.) Morley and Kananaskis, foot-hills of Rocky Mountains; Eagle Pass, B.C.; Spence's Bridge, B.C. (John Macoun.)

Drosera intermedia, Drev. \& Hayne, var. Americana, DC.

Upper West Branch, Hamilton River, Labrador, 1894. (A. P. Low, Herb. No. 4998.) Not before recorded from Labrador.

Lythrum alatum, Pursh.

Damp ground, Griffin Lake, B.C., 1889. (John Macoun.) Not before recorded in Canada west of Ontario, though found in Colorado. It is possible that the seeds of the Griffin Lake plants were in some way introduced, though this is not probable.

Aster PUNICEUS, L.

Lake Michikamow, Labrador, 1894. (A. P. Low.) Not before recorded from Labrador.

ANTENNARIA DIMORPHA, Torr \& Gray.

Clay banks near the Police Barracks, Medicine Hat, Assiniboia, 1894. (John Macoun, Herb. No. 5052.) Not before recorded east of British Columbia.

Helianthos tuberosus, $\mathrm{L}$.

H. doronicoides, Lam; Macoun, Cat. Can. Plants, vol. I., p. 246.

Along the Thames River at Chatham, Ont., 1894. (John Macoun, Herb. No. 5064.) Indigenous.

Tussilago Farfara, L.

Roadsides near Sutton Junction, Que. (Jas. Fletcher.) Near Toronto, Ont. (Mrs. White.) Along the shore of Cedar Island, Niagara River, Ont., 1894. (R. Cameron, Herb. No. 4941.) Not before recorded west of New Brunswick. 
Thelosperma AMbiguUd, Gray.

On the banks of the Saskatchewan River at Police Point, Medicine Hat, Assiniboia, May 31st, 1894. (John Macoun, Herb. No. 5073.) New to Canada.

Gilita minima, Gr.

All references under G. intertexta, Steud.; Macoun, Cat. Can. Plants, Vol. I., p. 330, go here.

Gidia intertexta, Steud.

Along an old road near Victoria, Vancourer Island, 1893. (John Macoun, Herb. No. 658.) First Canadian record.

Echixosperycy Redowsil, Lehm., var. cupdlatey, Gr.

Abundant in the vicinity of Medicine Hat, Assiniboia, 1894. (John Macoun, Herb. No. 5806.) Not before recorded east of British Columbia.

KrYNTTKIA CRASSISEPALA, Gray.

Dry prairies near Medicine Hat, Assa., 1894. (John Macoun, Herb. No. 5803.) Our only Canadian specimens, though recorded from the Saskatchewan in Gray's Flora of North America.

Mrosotis arvensis, Hoffm.

In a brook (No. 693) and on ballast (No. 694), at Nanaimo, Vancouver Island, 1893. (John Macoun.) Not. before recorded west of Ontario.

ASPERGo PROCUMBENS, L.

Along garden fences, Whitby, Ont., 1894. (Chas. McIllivray, Herb. No. 49jł.) New to Canada.

Convolvulus arvensis Linn.

Ashcroft, B.C. (Jas. McEvoy.) Cedar Hill, near Victoria, and on ballast heaps at Nanaimo, Vancouver Island. (John Macoun.) Not before recorded west of Ontario. 
:SALSOLA KALi, L., var. TRAGU,, DC.

Reported from several localities in Ontario. Abundant and spreading in Manitoba.

Euphorbia Preslit, Guss.

In cultivated fields near Chatham, Ont., 1894. (John Macoun, Herb. No. 5898.) The only specimens in our herbarium, though reported from Hamilton, Ont., by Buchan.

\section{SagitTaria, Linn.}

The publication of Mr. Snith's revision of the North American species of Sagittaria and Lophotocarpus in the Sixth Report of the Missouri Botanic Garden has so altered the nomenclature and has in a few instances so materially affected our knowledge of the distribution of the species known to occur in Canada, that a complete revision of the references given by Prof. Macoun in Parts IV. and V. of his catalogue is necessary: Many additional references are also given, and the descriptions of two easily confounded species are copied from Mr. Smith's revision, as it is in the hands of very few Canadian botanists. All our herbarium specimens have been examined by Mr. Smith.

S. ARIFOLIA; Nutt. in herb.

S. variablis, var. hastata, Macoun, Cat. Can. Plants, Vol. II., p. 77, forms $b$ and $c$ in part.

Terrestrial, or emergent aquatic, weak, ascending, 2 to $4 \mathrm{dm}$. high ; petioles rather stout, usually curving outward ; blade of leaf 6 to 12 or $18 \mathrm{~cm}$. long, arrow-shaped, acute, the margin mostly straight or arcuate, basal lobes divergent, acute or acuminate; scape weak, ascending, simple or rarely branched; bracts lanceolate, acute, 8 to $20 \mathrm{~mm}$. long, scarious margined and obscurely veined, often retlexed; 1 to 3 lower verticils pistillate; fertile pedicels ascending, 15 to mostly $25 \mathrm{~mm}$. long, or sometimes almost wanting; 
fruiting head round, 8 to $15 \mathrm{~mm}$. in diameter; achenium $2 \mathrm{~mm}$. long, tumid winged on both margins, the sides smooth, or often with a vertical subepidermal resin passage. Phyllodia of two forms, either long, slender, petiole-like, or flattened, linear-lanceolate, 2 to $5 \mathrm{dm}$. long and 10 to $15 \mathrm{~mm}$. wide.

Grande Vallée, Gaspé, Que. : Nipigon River, Ont. : Hand Hills and Eagle Hills, Alberta ; Sicamous, B.C. : Kamloops, B.C. (John Macoun.) Manitoba. (Bourgeau.) Moose Mountain Creek, Assa. (Jas. M. Macoun.)*

S. CUNEATA, Sheldon.

S. variabilis, var. diversifolia, Macoun, Cat. Can. Plants, Vol. II., p. 78, in part.

S. veriabilis, var. gracitis, Macoun, Cat. Can. Plants, Vol. II., p. 78, in part.

Eagle Hills, Alberta; Sicamous, B.C. (John Macoun.) South Thompson River, B.C. (Dr. G. M. Dauson.)

\section{S. LATIFOLA, Willd.}

Monœcious, with the lower verticils fertile, or diøcious: scape 1 to $12 \mathrm{dm}$. high, angled, simple or branched: flowers large, 2 to $t \mathrm{~cm}$. wide, the petals white; stamens numerous, 25 to 35 ; fertile pedicels shorter than the sterile; bracts sometimes connate in the upper verticils, acute, acuminate, or obtuse, not scarious; achenium broadly winged on both margins, 2.5 to 3.5 . or rarely $t \mathrm{~mm}$. long, with a lateral horizontal or curving beak $\frac{1}{4}$ to $\frac{1}{3}$ its length, sides usually smooth or with a costate angle curving downward from the base of the beak, rarely with a subepidermal resin passage on each face.

Mr. Smith recognizes five forms of this species, two of which with the species proper are found in Canada.

- No localities are given in this paper except those from which there are specimens In the herbarium of the Geol. Survey, or which are included in Mr. Smith's revision. 
S. latifolia, proper.

S. variabilis, var. hastata, form a, Macoun, Cat. Can. Plants, Vol. II., p. 77, in part.

North Pond, and Mt. Stewart, Prince Edward Island; Nation River, near Casselman, Ont. (John Macoun.) Ottawa, Ont. ( $W m$. Macoun.) Little Buffalo Lake, Sask. (Jas. M. Macoun.)

\section{Form a.}

S. variabilis, var. obtusa, Macoun, Cat. Can. Plants, Vol. II., p. 77, in part.

S. variabilis, var. angustifolia, Macoun, Cat. Can. Plants, Vol. II., p. 78, in part.

Campbellton, N.B. ( $R$. Chalmers.) Nation River at Casselman, Ont.; Belleville, Ont. (John Macoun.)

\section{Form $c$.}

S. variabilis, var. hastata, forms $b$ and $c$, Macoun, Cat. Can. Plants, Vol. II., pp. 77 and 78, in part.

Prince Edward Island; Bay of Quinté, Ont.; Lulu Island, mouth of Fraser River. (John Macoun.) New Brunswick. (Chadborne.) Lake Temiscouata, Que. (Northrup.) Missinaiba River, Ont. (Dr.R. Bell.) Manitoba. (Bourgeau.) Muskeg Island, Lake Winnipeg, Man. (Jas. M. Macoun.)

S. Latifolia, Willd., var. Pubescens, (Muhl.) J. G. Sinith.

S. variabilis, var. pubeseens, Macoun, Cat. Can. Plants, Vol. II.. p. 78.

Specimens collected in the Bay of Quinté, Ont., by Prof. Macoun, with pubescent bracts that are transition forms between this variety and the diøcious form $a$ of the species have been referred here by Mr. Smith.

S. RIGIDA, Pursh.

S. heterophylla, and var. rigida, Macoun, Cat. Can. Plants, Vol. II., pages 78 and 79. 
Abundant in many places about Ottawa, Ont. (Fletcher, $F l$. Ott.) In several places in the vicinity of Belleville, Ont., and Weller's Bay, Lake Ontario. (John Macoun.)

S. Graminea, Michx, Macoun, Cat. Can. Plants, Vol. II., p. 79.

Newfoundland. (Miss Brenton). North Sydney, Cape Breton, N.S.; Gull River, Victoria Co., Ont. (Juhn Macoun.) Several stations in New Brunswick. (Fouler's Cat.) Little Tobique River, N.B. (G. $C^{r}$. Hay.) Lake Mushoka, Ont. (Dr. Burgess, Dr. Britton and Miss Timmerman.)

Lophotocarpes CalyciNts, (Engelm.) J. G. Smith.

Sagittaria calycina, var. spongiosa, Macoun, Cat. Can. Plants, Vol. II., p. 78.

Several stations in New Brunswich. (Foneler, C'at.)

Listera AUSTRALIS, Lindl.

Poplar Ridge, Mer Bleue, near Ottawa, Ont., June 21st, 1893. (Jas. Fletcher.) New to Canada. Recorded in Ottawa Naturalist.

SCIRPUS SUbTERMTNALIS, Torr.

In the Columbia River at Revelstoke, B.C., 1890. (John Macoun, Herb. No. 7372.)

Eleocharis rostellata, Torr., var. occidextalis, Wats.

Near Ainsworth, Kootaine Lake, B.C., 1890. (John Macoun, Herb. No. 7386.) Not before recorded from B.C. mainland.

Agropyrum violacedM, Hornm.

East Main River, near James Bay. (A. H. D. Ross.) Attikanak Branch, Hamilton River, Labrador. (A.P.Lon:) Not before recorded from Labrador. 



Contributions from the Herbarium of the Geological Survey of Canada.

(By Permission of the Director.)

By JA.ues M. MACuTr;

Cumer of the Herbarimen.

VII.

Reprinted firm the C'unutiun Record of Sicience, Jily 1595. 

"Reprinted firm the Canadian Record of Srifure. July, 1895."

\section{Contributions to Canadian Botany.}

By James M. Macous.

VII.

ANEMONE NARCISSIFLORA, I.

Mount Heard, Burrough Bay, B.C., 1894. (H. W. E. Canarain.) Not hefore recorded from Canarla.

Rastactles aquatilis, L, var. CONFERToIdes, Wat.

In pools, Cape Chudleigh, Hudson Strait, 1884. (Dr. Robt. Bell.) Only Canadian record.

Cimicifuga elata, Nutt.

Mount Chean, Chilliwhack, Fraser Valley, B.C., Aug. 1st, 1895, alt. 7,000 feet, (Rer. Herbert H. Goucen.) New to Canada.

LATHYRUS PRATENSIS, Linn.

Well established in old fields at The Ledge, Dufferin, a few miles from St. Stephen, N.B. 1895. Collected by F. A. Pickett; communicated by Mr. J. Vroom. Only other record, Hamilton, Ont.

LEPTARRHENA PYROLIFOLIA, R. Br.

Additional stations for this species are: mountains in the vicinity of West Kootanie Lake, B.C.; mountains of the Selkirk Range, above 4,000 feet; and mountains of the Gold Range, B.C., above 5,000 feet. Not found east of the Columbia River along the line of the Can. Pac. Ry., though collected by Dr. Dawson in the Rocky Mountains in Lat. $49^{\circ} 30^{\prime}$, and by Drummond in Lat. $52^{\circ}$. 
Saxifraga Aizoon, Jacq.

In moist gravel, Charlton Island, James Bay, 1887. (Jas. M. Macoun.) Not recorded before from Hudson Bay.

SAXIFRAGA BRONCHIALIS, L.

Mountains north of Griffin Lake, B.C.; Eagle Pass, B.C. (John Macoun.) Harry Creek, Lake Okanagan, B.C. (Jas. McEvm.) Not before recorded between the Coast. Range and the Rocky Mountains. ${ }^{1}$

Saxifraga heterantha, Hook.

Toad Mountain, Kootanie Lake, B.C. (Jas. M. Macoun.) P'rotection Island, Nanaimo, Vancouver Island, and Mount Arrowsmith, V.I. (John Macoun.) Not before recorded from Vancouver Island.

Saxifraga integrifolia, Hook.

Hillsides at Sproat, Columbia River, B.C., 1890. (John Macoun.) Not before recorded from interior of British Columbia.

Saxifraga Lyalioit, Engler.

By alpine rivulets, Queest Creek, Shuswap Lake, B.C.; mountains at Griffin Lake, B.C., 1890. (Jas. M. Macoun.) Western limit.

\section{SAXIFRAGA NIVALIS, L.}

Borders of coulees, Cypress Hills, Assa., 1894. (John Macoun, Herb. No. 4921.2) Cornwall Hills, west of Asheroft, B.C. (Jas. McEvoy.) Francis River, Lat. $61^{\circ}$, Yukon District. (Dr. Geo. M. Dawson.)

SAXIFRAGA OCCIDENTALIS, Wat.

Eagle Pass, west of Revelstoke, B.C., 1890. (John

1 The Geographlcal limits given in theso papers refer to Canadi only.

2 Whenever herbarlum numbers are given, they are the numbers under which speot. mens have been distributed from the herbarlum of the Geological survey of Canada. 
Maconen.) All western references under S. Virginiensis, in Prof. Macoun's Catalogue, go here.

Saxifraga oppositifolia, Linn.

Mount Queest, Shuswap Lake, B.C., alt. 6,500 feet. (Jas. M. Macoun.) Not known to occur elsewhere near the line of the Can. Pac. Ry. between the Rocky Mountains and the Pacific.

Saxitraga PUNCtata, L.

Lat. $63^{\circ}$, Long. $102^{\circ}, 1893$. (Jas. W. Tyrrell.) First reeord east of Rocky Mountains. Mountain slopes south of Tulameen River, B.C., alt. 5,000. (Dr. Geo. M. Dauson.) Mount Chean, Fraser Valley, B.C. (Rex. H. H. Goven.) On rocks in a torrent, Mount Arrowsmith, Vancouver Island, alt. 2,000 feet. (John Macuen.) Mount Papho, Bradfield Inlet, B.C. (H. W. E. C'(unciun.) Not before reeorded in Canada west of Selkirk Mountains.

Saxifraga Ravunculifolia, Hook.

Crevices of damp rocks at sproat, Columbia River, B.C., alt. 4,000 feet. (John Macoun.)

Saxifraga rivelaris, L.

On lateral moraines at Poger's Pass, Selkirk Mountains, B.C., alt. 7,500 feet; crevices of rocks, Muunt Queest, Shuswap Lake, B.C., alt. 6,000 feet. (Jus. M. Mrucuun.) Not before recorded west of Rocky Mountains.

\section{Bevkinta . NutTaLiI,}

Shacifraga elata, Nutt.; Torr. \& Gray, Fl., Vul. I., p. ., .

Grassy thickets, Cowichan River, Vancouver Island, 1887. (John Macoun.) Near Victoria, Vancouver Island. (J. $K$. Anderson.) American botanists, since the publication of Torrey and Gray's Flora, have, with few exceptions, made Saxifraga elata, Nutt., a synonym of Boykinic 
occidentalis, Torr. \& Gray. Prof. Greene in Flora Franciscana (Pts. I.-II., p. 190) adopts Nuttall's specific name, but describes Boylinia occidentalis. Nuttall says "more -or less hirsute with long brownish hairs;" Greene says "glabrous or glandular pubescent ;" Nuttall says "a very remarkable, robust species ;" Greene says "slender." The leaves of Boykinia occidentalis are "thin-membranaceous," in our specimens referred here they are thick-coriaceous. The stem and petioles in our specimens are densely clothed with long brown or brownish hairs, and this character with the thick leaves makes it impossible to include them with Boykinia occidentalis. Nuttall's description of Saxifraga elata answers so well for these plants that they must be referred to that species. We have many sheets of BoyKinia occidentalis as described by Prof. Greene.

There seems no good reason why Saxifraga elata should ever have been made a synonym of Boykinia occidentalis, but since this has been done and the name Boykinia elata used it seems necessary to re-name Nuttall's plant.

Tellima tenelia, Walp.

Eagle Pass, west of Revelstoke, B.C.; Lytton, B.C.; Yale, B.C.; Cedar Hill and Burnside Road, near Victoria, Vancouver Island. (John Macoun.) Telegraph Creek, Lat. 58 ${ }^{\circ}$, B.C. (Dr. Geo. M. Dawson.) Recorded before only from Cypress Hills, Assa.

Tiarella laciniata, Hook.

Additional stations for this plant are Union Village, Comox, Vancouver Island, Herb. No. 227, and Goldstream, Vancouver Island, Herb. No. 228. (John Macoun.) Dr. Robinson considers this merely a form of T. trifoliata, but the characters separating it from that species are so well marked in all our specimens that Hooker's T. laciniata seems certainly to be at least a good variety. The con- 
spicuous characters are terminal leaflet deeply 3-cleft, the lateral ones 2 -cleft, the segments laciniate-pinnatifid. We have no intermediate forms between this and T. trifoliata.

\section{Mitelia Breweri, Gray.}

New stations for this species are Queest ('reek, Shuswap Lake, B.C., alt. 5,000 feet. (Jas M. Macoun.) Mountains at Griffin Lake, B.C., alt. 6,000 feet; mountains near Ainsworth, Kootanie Lake, B.C., alt. 5,500 feet; Asoulcan Glacier, Selkirk Mountains, B.C., alt. 5,500 feet. (John Macoun.)

\section{Chrysosplenium alternifolium, $\mathrm{L}$.}

New stations for this species are Kicking Horse Lake, Rocky Mountains. (John Macoun.) Between the North Thompson and Bonaparte Rivers, B.C. (Jas. M. Macoun.) Lat. $62^{\circ} 40^{\prime}$, Long. $103^{\circ}$. (Jas. W. Tyrrell.) Dease River, Lat. $59^{\circ}$, B.C. (Dr. Geo. M. Dawson.)

Parnassia fimbriata, Konig.

Mount Queest, Shuswap Lake, B.C., alt. 6,000 feet. (Jas. M. Macoun.) Mountains north of Griftin Lake, B.C.; Barclay Sound, Vancouver Island. (John Macoun.) Not before recorded west of Selkirk Mountains.

Parnassia Kotzebuei, Cham. \& Schl.

Damp banks, North Twin Island, James Bay, Hudson Bay; Mount Queest, Shuswap Lake, B.C.; Avalanche Mu., Selkirk Mts., B.C., alt. 7,500 feet. (Jas. M. Macoun.) Not before recorded from Hudson Bay or west of Rocky Mountains in Canada.

Parnassia parviflora, DC.

Grassy banks, Severn River, Keewatin; head of Deadman River, B.C. (Jas. M. Macoun.) Western limit. 
Ribes aUReum, Pursh.

Seven Persons' Coulee, Medicine Hat, Assa. (Joln Macoun, Herb. No. 4929.)

Ribes bracteosum, Dougl.

Low grounds, New Westminster Junction, B.C.; Burrard Inlet, B.C. (John Macoun.) Not before recorded from mainland of British Columbia.

Ribes Hudsontanum, Rich.

In swanups at Madoc, Hastings (o., Ont. (W. Scott.) Eastern limit.

Ribes laxiflorum, Pursh.

In damp woods near the summit of the Selkirk Range; B.C. (John Macoun.) Eastern limit.

Ribes viscosissimum, Pursh.

New stations for this species are Sicamous, B.C., and Deer Park, Lower Arrow Lake, B.C. (John Macoun.)

Sedum Douglasil, Hook.

Deer Park and Sproat, Columbia River, B.C.; Sicamous, B.C.; Mount Finlayson and Victoria Arm, Vancouver Island. (John Macoun.) Not before recorded west of Rocky Mountains.

Drosera Anglica, Hudson.

Revelstoke, B.C.; Horne Lake, Vancouver Island. (John Macoun). Not before recorded from interior of British. Columbia nor from Vancouver Island.

MyrtophyluU SPICATUM, L.

In pools on the Indian Reservation at Kamloops, B.C.: 
Somas River, near Sproat Lake, Vancouver Island. (John Macoun.) Not before recorded west of Selkirk Mountains.

MYRtophyludu VERTICILLATUM, I.

Rivière des Aulnais, Hebertville, Que. (St.Cyr.) Not before recorded from Quebec.

Hippunis montana, Ledeb.

Peaty places on all the higher mountains of the Selkirk Range, B.C., near the Can. Pac. Ry.; mountains north of Griffin Lake, B.C. (John Macoun.)

CENothera PUMiLa, L.

On a barren, uncultivated slope at New Westminster, B.C., 1895. (A. J. Hill.) Not before recorded west of Ontario. Perhaps introduced, but thought to be indigenous by Mr. Hill.

Enothera ANDINa, Nutt.

In a depression on the prairie near Police Point, Medicine Hat, Assa., 1894, Herb. No. 7531. On prairies near Pend d'Orielle Post, Milk River, Assa., 1895. Herb. No. A1001. (John Macoun.) New to Canada.

\section{LYTHRUM SALicaria, L.}

Near the old rifle range, Ottawa, Ont., 1895. (A. L. Tourchat.) Not recorded from Eastern Ontario. Mr. Tourchat's specimens are of the glabrous form with long style and medium stamens. All our other specimens are pubescent or hoary and have medium styles and long stamens.

Solidago lanceolata, L.

Okanagan Lake, B.C. (Jas. McEvoy.) Not recorded west of Rocky Mountains. 
Adenocaulon bicolor, Hook.

Indian Reserve, Cape Croker, North Bruce, Ont., 1895. (A. Y. Massey.) Eastern limit. Not before collected in Canada east of the Rocky Mountains.

Ambrosia trifida, L。

Along the Can. Pac. Ry., at Revelstoke, B.C.; barn-yards near Victoria, Vancouver Island, Herb. No. 4:37. (John. Macoun.) Probably introduced in both cases. Not recorded west of Manitoba. The Cypress Hills specimens referred here in Prof. Macoun's Catalogue of Can. Plants are var. integrifolia.

RUdBeckia PINNATA, Vent.

Vicinity of Sandwich, Ont. (John Macoun. Alex. Wherry.) New to Canada.

Microseris nutans, Gray.

Amongst grass on hillsides at Deer Park and Sproat, Columbia River, B.C., 1890. (John Macoun.) Credited to British Columbia by Gray, but not before collected by Canadian botanists.

Crepis runcinata, Torr. \& Gray.

Dampish spots at Revelstoke, B.C.,1890. (John Macoun.) Not recorded west of Rocky Mountains.

Crepis intermedia, Gray, var. Gracilis, Gray.

Dry slopes at Spence's Bridge,B,C.,1889. (John Yacoun.) New to Canada.

Lobelia KaLMir, L.

Rocky shores of Kootanie Lake at Ainsworth, B.C. (John Macoun.) Western limit. 
Spteularia perfoliata, A. DC.

Sproat, Columbia River, B.C. (Dr. Geo. M. Dawson.) Ainsworth, Kootanie Lake, B.C., and Agassiz, B.C. (John Macoun.) Not before recorded from interior of British Columbia.

Heterocodon rariflorum, Nutt.

Crrassy slopes at Sproat, Columbia River, B.C. (John Macoun.) Not before recorded from mainland of British Columbia.

Pterospora andromeda, Nutt.

Wooded mountain slopes west of Lake Okanagan, B.C., 1890. (Jas. McEroy.) Not before recorded from mainland of British Columbia.

Gentiana Douglasiana, Bong.

Mount Head, Burrough Bay, B.C., 1894. (H. W. E. Canceun.) Yakoun Lake, Queen Charlotte Islands, 1895. (Dr. C. F. Newcombe.)

Gentiana humilis, Stev.

On the north side of an old creek bed on the south bank of the Bow River at Langevin Bridge, Alberta, 1894 (J. J. Morgan.) New to Canada.

Gentiana linearis, Froel.

Not rare in the interior of Labrador from the East Main River on the west to the Hamilton River on the east. (A. P. Low.)

\section{Phlox maculata, L.}

Ravine at Granby, Que., 1892. ( $W m$. Scott.) High Falls, Lièvre River, Que., 1895. (R. B. Whyte.) New to Canada. 
Bartsia alpina, $\mathbf{L}$.

Lake Petitsikapau, Hamilton River, Labrador, 300 miles from the coast. (A. P. Low.) Not before recorded from interior of Labrador.

Brunelia vUlgaris, I.

Attikonak Branch, Hamilton River, Labrador, 1894. (A. P. Lou:) Not before recorded from Labrador.

QUERCUS PRIN.US, L.

A few trees grow near the St. Lawrence River at Lansdowne, Ont. Noted by the Rev. C. J. Young in 1894, fruiting specimens collected in 1895. This is the only authentic record for this species east of Niagara. The undulately-crenate leaves of this species, pale and minutely downy beneath, make it very easy of determination. Specimens from the Bay of Quinté are Quereus Muhlenbergii, (Q. prinoides of Macoun's ('at. of Can. Plants.)

Tofieldia glutinosa, Willd.

Attikonak Branch, Hamilton River, Labrador, 1894. (A. P. Lou:) Not before recorded from Labrador.

Dulichium spathaceum, Pers.

Craigellachie, Eagle Pass, B.C.; Stanley Park, Vancouver, B.C. (JohnMacoun.) Not before recorded between the Saskatchewan and Vancouver Island.

Carex scirpoinea, Michx.

On the route between Sandy Lake and Lake Michikamau, Labrador, 1894. (A. P. Low.) Not before recorded from Labrador.

Carex Capillaris, Linn.

On the route between Sandy Lake and Lake Michi. 
kamau, Labrutor, 1894. (A. P. Lmr.) Not before recorderl from Labrador.

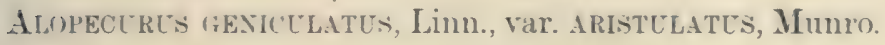

(O) the route between Sandy Lake and Lake Michikamau, Labrador, 1894. (A. P. Lor .) Not before recorderl from Labrador.

Munroa squarrosa, Tort.

Near the police barracks, Merlicine Hat, Assa,, 1894. (John Macoun, Herb. No. 7452.) 





\section{Contributions from the Herbarium of the Geological Survey of Canada.}

(By Permission of the Director.)

By JAMrs M. MACovi,

Curator of the Herbarivm.

\section{VIII.}

Reprinted from the Canadian Recorl of Science, October, 1895. 

"Reprinted from the C'enterlien Recorl of s'sience, Oclaber"; 1895."

\section{Contributions to Canadian Botany.}

By James M. Macoun.

\section{VIII.}

Aquilegia Jonesir, Parry.

High slopes of Sheep Mountain, Waterton Lake, Rocky Mountains, Lat. 49²5', July 29th, 1895. (Juhn Mecoun, Herb. No. 10,029.) New to Canąda.

Berberis nervosa, Pursh.

Not rare in cleep, moist woorls in Trinity Valley, between Mabel Lake and Enderby, B.(., 1895. (Jres. McEv!!, Herb. No. 10,133.) Not before recorded east of Yale, B.C.

Berberis aquifolity, Pursh.

In open thickets, Waterton Lake, Lat. 49"05', liocky Mountains, 1895. (Jokn Mecoun. Herb. No. 10,267.) Eastern limit in Canada.

Papaver Prrexaicum, L.

A single specimen collected by Dr. G. M. Dawson in the South Kootanie Pass, Rocky Mountains, 1883. Re-discovered in 1895 by Prof. John Macoun on sheep Moumtain, Waterton Lake, Rocky Mountains, alt.,, 500 feet, Lat. $49^{\circ} 05^{\prime}$. Herb. No. 10,269. New to America.

LEsquerella Ludoviciaxa, Wats.

Specimens collected at Medicine Hat, Assa., by l'rof. John Macoun, in 189;, (Herb. No. 10,308) are the only specimens in gir herbarium that can be referred here. The pubescence of the oblanceolate radical leaves is conspicuously stellate. 
Lesquerella Ludoviciana, Wats., var. ARenosa, Wats.

Vesicaria Ludoviciana, Macoun, Cat. Can. Plants, Vol. I., p. 54, in part, and Vol. 1., p. 490.

From Western Manitoba to the Saskatchewan. The reference under $L$. Ludoviciana, Wats., var. arenosa, Wats., Macoun Cat. Can. Plants, Vol. II., p. 305, should go with L. arctica, Wat.

Sisymbrium virgatum, Nutt.

In gravel amongst bushes, Police Point, Medicine Hat, Assa. In fruit May 31st, 1894 . Herb. No. 3,069; prairies, 12-Mile Lake, Wood Mountain, Assa., June 6th, 1895. Herb. No. 10,007; meadows, Sucker Creek, Cypress Lake, Assa., 1895. Herb. No. 10,006. (John Macoun.). New to Canada. The Canadian specimens have longer pedicels and pods and are more paniculately branched than those from the Rocky Mountains in the United States, but Dr. Robinson, who examined our specimens, has been unable to detect a single significant or constant character to separate the plants from the two regions.

Arabis Drummondi, Gray: Macoun, Cat. Can. Plants' Vol. I., p. 43 , in part.

A. Lyallii, Macoun, Cat. Can. Plants, Vol. I., p. 43; and Vol. I., p. 487, in part: J. M. Macoun, Can. Rec. Science, Vol. VI., p. 145.

From the Cypress Hills, Assiniboia, west to the Gold Range in British Columbia. Our specimens are from Cypress Hills, Assa.; Sheep Mountain, Waterton Lake, liocky Mountains; mountains north of Devil's Lake, and at Kicking Horse Lake, Rocky Mountains. (John Maconn.) Maple Creek, Assa. : Toad Mountain, Kootanie Lake, B.C: Mount Queest, Shuswap Lake, B.C, (Jas. M. Macoun) Rocky Mountains, (Drummond.) 
Arabis Lyaluit, Wals.

Our specimens of this species are from West Summit of North Kootanie Pass. (Dr. G. M. Dacson.) Shore of Waterton Lake, Pocky Mountains; mountains north of Devil's Lake, Rocky Mountains. (John Macoun.) Lookout Mountain, Big Bend of Columbia River, B.C. (Prof. Coleman.)

Viola Howeliti, Gray.

$V$. canina, L. var. sylvestris, Macoun, Cat. Can. Plants, Vol I., p. 63 in part.

V. cunina, L. var. longipes, Macoun, Cat. Can. Plants, Vol. I., p. 493 in part.

- In woods, New Westminster, B.C.: C'edar Hill, shawnigan Lake and Nanaimo, Vancouver Island. (John Macoun.) Vancouver Island (Strects, vide Syn. Fl. North Am. Vol. I., p. 202.)

Viola orbiculata, Geyer; re-elescribed and figured in Contr. from U.S. Herbarium, Vol. III., No. 4, p. 214. V. sarmentose, Macoun, Cat. Can. Plants, Vol. I., p. 493 in part.

V. surmentosa Dongl. var. orbiculata, Robinson, Syn. Fl. N. Am., Vol. I., p. 199.

Western Summit of North Kootanie Pass, Rocky Mountains; Jean or Salmon River, B.C. (Dr. G. M. Dauson) Kicking Horse Lake, Rocky Mountains; summit of Selkirk Mountains, B.C.; Revelstoke, B.C. ; mountains near Ainsworth, Kootanie Lake, B.C. (John Macoun.) Viola sarmentosa Dougl. seems in Canada to be contined to the Coast Range and Vancouver Island, all our specimens from the interior being plainly V. orbiculata, Geyer. The two plants have always been separated in our herbarium, though all were named $V$. sarmentosa. 
Arenaria congesta, Nutt.

Open prairies. Sweet Grass Hills, Alberta, just north of the International Boundary, 1895. (John Macoun.) Not before recorded from Canada.

Claytonia megarrhiza, Parry.

Additional references for this species are: summit of Saddle Mountain, Banff; Rocky Mountains; summit of Sheep Mountain, Waterton Lake, Lat. $49^{\circ}$ 05', Rocky Mountains, Herb. No. 10,091. (John Macoun.)

Hypericum kalmianum, L. ; Macoun. Cat, Can. Plants, Vol. I., p. 84 .

On a small rocky island in the Ottawa River, Township Clarendon, Pontiac Co., Que. In Hower July 24th, 1895. (Robt. H. Coviley.)

Nemopanthes Canadensis, DC.

Banks of west branch of Nottaway River, N.E. Ter., 1895. (Dr. R. Bell.)

Lupinus pusillus, Pursh.

L. Kingii, Macoun, Cat. Can. Plants, Vol. I., 10:3.

Dry sand hills, five miles west of the northern elbow of the South Saskatchewan; Crane Lake, Assa., Herb. No. 4,06S ; Police Point, Medicine Hat, Assa., Herb. No. 4,069; South of Wood Mountain, Assa.; Many Berries Creek, Milk River, Assa., Herb. No. 10,412; Milk River, Assa., Herb. No. 10,414. (John Macoun.) Along the Belly River, Alberta. (Dr. Geo. M. Dawson.)

Lcpinus minimus, Dougl.; Macoun, Cat. Can. Plants, Vol. I., p. 103.

Sunımit of Sheep Mountain, Waterton Lake, Lat. $49^{\circ} 05^{\prime}$, alt. 7,500 ft., July 31st, 1895. (John Macoun, Herb. No. 
10,41:3.) The only authentic (anadian record, as it is cloubtful whether it was found by Douglas north of the boundary.

\section{Cicer arietinum, L.}

Vicia (?), Macoun, Cat. Can. l'lants, Vol. I., p. 512.

In dry soil at ('hinaman's Ranch, above Spence's Bridge, Thompson River, B.C., Aug. 188:?. (Jas. Fletcher.) Introduced in wool at Wingham, Ont., 1891. (J. A. Morton.) A native of Bengal.

\section{Spir.a betulifolia, Pall.}

Peel's River, Mackenzie River Delta, July 14th, 189:?. (Miss E. Taylor.) Specimens from Qualco Lake, B.C., collected by I)r. (;. M. Dawson, are doubtfully referred here. These are the only specimens of this species in our herbarium.

Siprefa lecida, Iougl. ; Pittonia, Vol. II., p. 르1.

S. betulifolia, Macoun, Cat. Can. Plants, Yol. I., p. 1206, in part.

Common in thickets and on hillsides, from the Rocky Mountains westward. Our specimens are from Kootanie Pass, Rocky Mountains. (Dr. G. M. Datson) Valleys of the Rocky Mountains. (Drummond) Waterton Lake, Lat. $4905^{\prime}$, Rocky Mountains: Bow River Pass and Kicking Horse Lake, Rocky Mountains: Sproat and Ieer Park, Columbia River, B.C.: sicamous, B.C.: Spence's Bridge, B.C. (John Macoun.) lied Deer, Alberta. (H. H. Gaetz )

Siprata ARbtsccla, Greene, Erythea, Vol. III.. p. 63.

S. betulifolia, Pall., var. rosea, Gray : Macoun, Cat. Can. Plants, Vol. I., p. 513.

In woods and thickets at the summit of the Selkirk Pange, B.C. (John Macoun. Jas Fletcher.) 
Neillia opulifolia, Wats.

Banks of West Branch of Nottaway River, N. F. Ter., 1895. (Dr. R. Bell.)

Potextilla uvina.

P. dissecta, var. pinnatisecta, Macoun, C'at. C'an. I'lants, Vol. I., p. 517.

Low, tufted, the multicipitous ligneous caudex partly subterranean and clothed with the persistent bases of the leaves; leaves $1 \frac{1}{2}$ to 4 inches long of from 4 to 7 pairs of pinne, these parted into 2 or 3 linear pinne, villous-pilose at apex and sparingly so on both surfaces. Flowering stems scarcely leafy, 4 to 6 inches high, the flowers on slender pedicels an inch or two long: achenes few, obliquely obovoid, smooth and glabrous.

High slopes of ('astle Mountain, liocky Mountains, Herb. No. 7,242; crevices of rocks at The Mound, Banff, Rocky Mountains, Herb. No. 7,235; Sheep Mountain, Waterton Lake, Lat. $49^{\circ} 05^{\prime}$, Rocky Mountains, Herb. Nos. 10,488, 10,489. (John Macoun.)

Though considered a variety of $P$. Plattensis by 1)r. Watson, Prof. Macoun always believed the Rocky Mountain plant to be quite distinct from that species, and more nearly related to $P$. dissecta. Later he came to the conclusion that it was a good species, and in this opinion he is sustained by Dr. Edw. L. Greene, who has examined the specimens collected on Sheep Mountain in 1895. The above preliminary description is based on his diagnosis. Prof. Macoun has seen the specimens labelled P. Plattensis, var. pinnatisecta in the Grey Herbarimm, and believes them to be all referable here.

\section{Callitriche hamulata, Kürtz.}

Dr. Morong having examined the specimens referred to this species (Macoun Cat. Can. Plants, Vol. II., p. 322, ) 
pronounced them to be $C$. verna, L. We have no authentic Canadian specimens of $C$. hamulata.

LUdWigia PALUSTRis, Ell.

Wet places, Sproat Lake, Vancourer Island, 1857. (John Macoun.) Not before recordel west of the Saskatchewan.

Gayophytum ramosissimum, T. \& 6 .

Near Dog Lake, Okanagan Valley, B.C., 1895. (Jus. Fletcher;) New to Canada.

\section{SANICULA,}

Following Mr. Bicknell's revision of the eastern species of this genus, our herbarium specimens have been arranged as below :-

S. Marmlandica, L.

From New Brunswick and Nova S'cotia west to Yancouver Island.

$\therefore$ Gregaria, Bicknell, Bull. Torr. But. Club, Vol. XXII., p. 354 .

Near Belleville, Ont. (John Mucoun) Wingham, Ont. (J. A. Morton.)

S. Canadensis, I.

We have, in our herbarimm, no specimens of this species as diagnosed by Mr. Bicknell, though it may be common enough throughout Eastern Canada.

$\therefore$ Trifoliata, Bicknell, Bull. Torr. Bot. C'lub, Vol. XXII., p. 360 .

Casselman, Ont.: Hastings Co., Ont. : Amberstburg, Ont. (John Macomn.) This Semicula, with conspicuously 
trifoliate, petioled cauline leaves, has been generally taken in Canada to be typical $S$. Canadensix, L.

OSMORRHIZA BREVISTYLIS, DC.

From Prince Edward Island west to Lake Winnipeg.

Osmorrhiza longistylis, DC.

From Nova Scotia west to the Saskatchewan.

-Osmorrhiza nUda, Torr.

From the Eastern slope of the Rocky Mountains west to Vancouver Island.

Osmorrhiza occidentalis, Torr.

Mountain woors at Ainsworth, Kootanie Lake, B.C., alt, 5,,000 ft., 1S90. (John Macoun.) A new station for this plant.

Cicuta Caltfornica, Gray.

New Westminster, B.C.; Ainsworth, Kootanie Lake B.C. (John Macoun.) Not before recorded from British Columbia mainland.

Cardu Carui, L.

Waste places near the brick-yard at Banff, Rocky Mountains. (John Maconn.)

Ligusticly Grayi, C.\& R.; Macoun, Cat. Can. Plants, Vol. II., p. 327.

Woods on the mountains at Ainsworth, Kootanie Lake, B.C., alt. 5,000 feet. (John Macoun.)

Ligusticem scopulorum, Gray.

Specimens collected by Prof. John Macoun, at Roger's l'ass, Selkirk Mountains, B.C., in 1890, have been doubt- 
fully referred here by Prof. Coulter. Not before recorderl from Canada.

Helianthes GRosse-serrates, Martens.

Along the Grand Trunk Railway, near Stanford, Ont., 1895. (R. Cameron.) Introduced from United States.

Cladothamyus campayclatus, Greene, Erythra, Vol. III., p. 65.

Shrub 3 to 5 feet high, with few and stoutish ascending branches; leaves lanceolate, 1 to 3 inches long, tapering to a short petiole, which, together with the veins beneath, is more or less strigose-hirsute with red hairs; flowers solitary or in pairs or threes, from lateral buds, on pedicels $\frac{1}{2}$ inch long, those setose-hispid with red hairs; sepals ovate-oblong, densely ciliate with short gland-tipped hairs; corolla light salmon colour, campanulate, the petals joined at base into a short tube ; anthers opening only by a pair of large round terminal pores.

Credited to British Columbia by Dr. Greene, but all our specimens, both from Vancouver Island and the mainland, are $C$. pyrolaftorus, Bong. The new species should be looked for by collectors in British Columbia on the higher mountains of the Coast Range. We have specimens of C. pyrolceflorus collected at Sitka by Bongard himself.

VINCA MajoR, Linn.

In fields near Victoria, Vancouver Island, 1893. (John Macoun.) Escaped from gardens.

Gevtiana Platypetala, Griseb.

Mount Rapho, Bradford Inlet, Lat. $56^{\circ} 13^{\prime}$, Long. 131 $36^{\prime}$, alt. 4,050 ft., July Tth, 1894. (H.W.E.Canucan.) Yakoun Lake, Queen Charlotte Islands, 1895. (Lr. C.F. Nexcombe.) New to Canada. 
Meryanthes Crista-galdi, Menzies.

Port Simpson, B.C., 1893. (Jas. McEvoy.) Shore of Yakoun Lake, Queen Charlotte Islands, 1895. (Dr. C. F. Newcombe.)

Mrosotis cesspitosa, Schultz.

Cartwright, Ont., 1891. (W. Scott.) New to Canada.

Solanum nigrum, L., var. villosum, Mill.

A new station for this plant is New Westminster, B.C. 1895. , (A. J. Hill.)

Verbascum thaspUs, L.

Waste plates, Revelstoke, B.C.; Vernon, Lake Okanagan, B.C., and Sannach Road, near Victoria, Vancouver Island. (John Macoun.) Not before recorded west of Ontario.

Verbascum BLATtakia, L.

Waste places, Revelstoke, B.C. (John Macoun.) On the sea shore at Union Mines, Comox, Vancouver Island. (Auderson.) Not before recorded west of Ontario.

Chelone glabra, Limn.

Banks of west branch of Nottaway River, N.E. Ter., 1895. (Dr. R. Bell.)

Eunanus Breweri, Greene.

Amongst grass on hillsides at Sproat, Columbia River, 1890. (John Macoun, Herb. No. 10,307.) New to C'anada. Determined by Dr. Greene.

Thymus Chamedrys, Fries.

Stanley Park, Vancouver, B.C., September, 1895. (Rev. H. H. Goven.) T. Serpyllum, L., is not uncommon in 
Eastern America, but this species has not been before recorded from this country.

Calamintha cliyopodium, Benth.

New Westminster, B.C., 1895. (A. J. Hill.) Not recorded west of Manitoba. Probably introduced.

Pogonia ophioglossoides, Ker.

In bogs, near small lakes at head of (iatineau River, Que. (Dr. R. Bell.)

Altivm Geyeri, Wats.

(iravelly banks, Botanie, west of Spence's Brilge, B.C., 1890. (Jas. McEroy.) Found on Vancouver Island, but not before on mainland of British Columbia. Referred by mistake to Allium Nerii, Wats., in No. II. of these papers.

Aldidu acrmatim, Hook.

On gravelly banks, Botanie, west of spence's Bridge, B.C., 1890. (Jas. McEtoy.) Not before recorded from mainland of British Columbia.

C'arex festiva, Iew., var. Gracilis, Olney.

Borders of coulees, Cypress Hills, Assa., 1894. (John Macoun, Herb. No. 7,396.) Not before recorded east of British Columbia. 



Contributions from the Herbarium of the Geological Survey of Canada.

(By Permission of the Director.)

By JAMEs M. MAcous, Curator of the Herbariam.

IX.

Reprinted from the Canatian Record of Science, Jan. and A pril, 1896. 

"Reprinted from the Canadian Record of Science, Jan. and A pril, 1896."

\section{Contributions to Canadian Botany.}

By Jamrs M. Macour.

IX.

DeLPHINIUM SIMPLEX, Dougl.

About two miles above the mouth of the Kootanie Piver, B.C., 1889. (John Macoun, Herb. No. 10,597.) New to Canada.

Alyssum calycinum, L.; Macoun, Cat. Can. Plants, Vol. I., p. 53.

Near Blackwell Station, Lambton Co., Ont. ( $T$. $C$. Wheatley.)

Trans, R. Soc, Can, XII. iii. 30. 
Polygala incarnata, L.

Walpole Island, Lambton Co., Ont., 1894. (C. K. Dodge.) New to Canada.

Polygata senega, L., var. latifolia, T. \& G.

Georgian Bay, Lake Huron, 1889. (J. M. Dickson.) New to Canada.

Sagina Decumbens, Torr: \& Gray; Macoun, Cat. Can. Plants. Vol. I., p. 79.

Hillsides, Farewell Creek, Cypress Hills, Assa. Herb.

- No. 11,710. ${ }^{1}$ (John Macoun.)

Desmodidm Marilandicum, F. Boott.

Near Blackwell Station, Lambton Co., Ont., 1893. (T. C. Wheatley.) New to Canada.

Desmodium rotundfolium, DC. ; Macoun, Cat. Can. Plants, Vol. I., p. 118.

Niagara Falls, Ont. (R. Cameron.) Near Blackwell Station, Lambton Co., Ont. (C. K. Dodge.)

VICIA SEPIUM, L.

In ditches in a ravine west of Hamilton, Ont. ( $J . M$. Dickson.) New to Canada. Introduced.

Ludwigia Polycarpa, Short \& Peter.

Since recording in Part I. of these papers the occurrence of this species, at Anherstburg, it has been reported from the vicinity of Sarnia by Mr. Chas. K. Dodge.

Epilobium Watsoni, Barbey.

New Westminster, B.C. (A.J.Hill. Rev. H. H. Gowen.) New to Canada.

1 Whenever herharium numbers are given, they are the uumbers under which specimens have been distributed from the herbarium of the Geological Survey of Canada. 
LYTHRUM SALICARIA, I.

In No. VII. of these papers, it was stated that this species had not been recorded from Eastern Ontario until found at Ottawa, in 1895, by Mr. Tourchat. This was a mistake. It had been before collected at Ottawa by Mr. William Scott, and was recorded in Flora Ottaucaensis, p. 32.

\section{Pastinaca sativa, L.}

Spence's Bridge, B.C.; common in old gardens and waste places on Vancouver Island. (John Macoun.) Not recorded west of Manitoba. ${ }^{1}$

Peucedanum eurycarpum, C. \& R.; Macoun, Cat. Can. Plants, Vol. I, p. 329.

From the east end of the Cypress Hills west to the Pocky Mountains, 1894, 1895. Herb. Nos. 4,963 and 10,692-3-4-5. (John Macoun.) Not before recorded east of Rocky Mountains.

Peucedanem triteriatum, Nutt.; Macoun, Cat. Can.

Plants, Vol. I., pp. 187 and 536; and Vol. II., p. 329.

Milk River, Assa. Herb. No. 10,688. (John Macoun.) Eastern limit.

Daucus carota, L.

Common in meadows on Vancouver Island, and apparently naturalized.

Corves pubescens, Nutt. ; Macoun, Cat. Can. Plants, Vol. I., pp. 191 and 538.

Donald, Columbia River, B.C.; north of Pass Creek, Sproat, B.C. (John Macoun.)

Cornus pcbescexs, Nutt., var. Californica, C. \& E.

Woods at Revelstoke, Columbia River,B.C:.,1890. (John Macoun.) Only Canadian station.

1 The geographical limits given in these jayers refer to Canada ouly. 
Nyssa aquatica, L.

N. multiflora, Wang.; Macoun, Cat. Can. Plants, Vol. I., p. 192.

Many fine trees of this species grow at Queenston Heights, and near Niagara-on-the-Lake, Ont., but it has apparently never been recorded from that vicinity.

Adoxa Moschatellina, L. ; Macoun, Cat. Can. Plants, Vol. I., p. 193.

Athabasca River, below the Cascades. (Miss E. Taylor.) Athabasca River, Lat. 56 . (Jas. M. Macoun.)

Sambucus glauca, Nutt.; Macoun, Cat. Can. Plants, Vol. II.. p. 331.

In woods at Deer Park, Lower Arrow Lake, Columbia River, B.C. (John Macoun.) Eastern limit.

Viburnum dentatum, L. ; Macoun, Cat. Can. Plants, Vol. I., pp. 194 and 538.

Foster's Flats, Niagara River, Ont. (John Macoun.) Near Sarnia, Ont. (C.K. Dodge.)

Viburnum Opulus, L. ; Macoun, Cat. Can. Plants, Vol. I., p. 195.

Prof. Macoun, in his Catalogue, makes the Saskatchewan the western limit of this species. We have now specimens from Sproat, B.C.; Sicamous, B.C.; and Agassiz, B.C. (John Macoun.)

Lonicera ciliosa, Poir. ; Macoun, Cat. Can. Plants, Vol. I., p. 196.

Woods at Sproat and Deer Park, Columbia River, B.C.; Yale, B.C. (John Macoun.)

Lonicera Utahensis, Wats.; Macoun, Cat. Can. Plants, Vol. I.', p. 540.

Sheep Mountain, Waterton Lake, Rocky Mountains; 
Deer Park, Lower Arrow Lake, B.C.; Revelstoke, B.C.; Sicamous, B.C. (John Macoun.)

Galicy aparine, L.; Macoun, Cat. Can. Plants, Vol. I., p. 200.

The only western station for this plant given by Prof. Macoun is Victoria, Vancouver Island. It has since been found to be of very general distribution in British Columbia. Our specimens are from Elk River Brilge, Rocky Mountains. (Dr. Geo. M. Darson.) Deer Park, Lower Arrow Lake, Columbia Piver, B.C. ; Ainsworth, Kootanie Lake, B.C.; Kamloops, B.C.; Yale, B.C.: Agassiz, B.C. ; Lulu Island, B.C.: Salt Spring Island, Gulf of Georgia : common on Vancouver Island. (John Macoun.) Specimens from some of the above localities have been distributed as var. Vaillantii, Koch, but they are true G. Aparine. We agree with Dr. Greene that though this species is "as much at home in our woods and thickets as any indigenous plant, it is probable that it came hither from the Old World within the last two centuries."

Sherardia arvensis, I.

In fields, Victoria, Vancouver Island, 1893. (John Iacoun.) Not before recorded west of Ontario.

Asperdla ARVExsis, L

Edge of a marsh, near Hamilton, Ont. (J. M. Dickson.) New to Canada.

Liatris scariosa, Willd.; Macoun, Cat. Can. Plants, Vol. I., p. 208.

Near Sarnia, Lambton Co., Ont. (C. K. Dorlge.) Not recorded from Ontario since collected by Maclagan. Not having seen Maclagan's specimens, Prof. Macoun, when preparing his Catalogue, was of the opinion that Maclagan's stations for $L$. scariose should be referred to L. cylindrica. 
Aster concinnus, Willd.

A specimen of this rare Aster was sent to our herbarium by Mr. Eugene A. Rau in December, 1890. The label reads thus: "Moraviantown (formerly called New Fairfield) near railroad station, Bothwell, Ontario, Canada. Collected by Robert Rau, Sept. 30th, 1872. Identified by Prof. Porter." Specimens collected by Jas. M. Macoun, at Point Edward, Ont., in 1884, have been doubtfully referred here. They differ very slightly from Mr. Rau's specimen, and are not referable to any other species.

Aster conspicuus, Lindl.; Macoun, Cat. Can. Plants, Vol. I., pp. 220 and 544.

In rocky thickets at Sicamous, B.C. (John Macoun.) Western limit.

Erigeron armeriefolius, Turez; Macoun, Cat. Can. Plants, Vol. I., p. 235.

Additional stations for this species are: Chaplin, Old Wives Lakes, Assa., Herb. No. 10,840 ; Fort Walsh, Cypress Hills, Assa.; Hand Hills, Alberta; St. Mary's River, Alberta, Herb. No. 10,839; Cave Avenue, Banff, Rocky Mountains; Sicamous, B.C.; Kamloops, B.C. (John Macoun.) Not before recorded west of the prairie region.

Erigeron ochroledcus, Nutt.

Summit of Sheep Mountain, Waterton Lake, Rocky Mountains. Herb. No. 10,858. (John Macoun.) New to Canada. Flowers purplish, turning to a dirty chrome yellow when the specimens have been badly dried. The description in Torr. \& Gray, Fl. II., p. 178, is a much better one than that in Gray's Syn, Flora.

Erigeron strigosus, Muhl.; Macoun, Cat: Can. Plants, Vol. I., p. 234.

Near Belly and St. Mary's rivers, Alberta; Griffin Lake, B.C. ; Sproat, B.C. ; Ainsworth, Kootanie Lake, B.C.; 
Alberni, Vancouver Island. (John Macoun.) Not before recorded west of Assiniboia. The Sproat specimens are the var. discoideus, Robbins.

Erigeror uxiflorts, L.; Macoun, Cat. Can. Plants, Vol. I., pp. 231 and 547.

Summit of Avalanche Mountain, Selkirk Mts., B.C.; Mt. Queest, Shuswap Lake, B.C. Alt. 6,000 feet. (Jas. M. Macoun.) Not recorded before from British Columbia. Specimens from Kicking Horse Lake, taken from a landslide at the foot of a mountain, show a great divergence in habit from those collected at the summit of the same mountain, 3,000 feet higher. These latter are scarcely an inch in height, and have in some cases a barely perceptible stem; the plants from the lower levels are more than a foot high.

Antenvaria alpixa, Grertn.; Macoun, Cat. Can. Plants, Vol. I., pp. 236 and 548.

Mountains north of Griftin Lake, B.C.; Revelstoke, B.C. ; Spence's Bridge, B.C. : summit of Mount Arrowsmith, Vancouver Island. (John Macoun.)

Antexyaria Carpathica, R.Br.; Macoun, Cat. Can. Plants, Vol. I, pp. 236 and 548.

Additional stations for this species are: mountains at Roger's Pass, Selkirk Mts., B.C., alt. 6,500 feet; near Ainsworth, Kootanie Lake, B.C.; Spence's Bridge, B.C. (John Macoun.) Mount Queest, Shuswap Lake, B.C.; mountains at Griffin Lake, B.C. (Jas. M. Macoun.) Sucker Mountain, B.C. (Jas. McEvoy.)

Antennaria Carpathica, R. Br., var. PClcherrima, Hook. Macoun, Cat. Can. Plants. Vol. I., pp. 237 and 548.

Guichon Creek, B.C.; mountains south of Tulameen River, B.C. (Dr. Geo. M. Dawson.) Spence's Bridge, 
B.C.; Câche Creek Mountain. B.C. (John Macoun.) The Câche Creek specimens were referred to $A$. Carpathica in Prof. Macoun's Catalogue. Not before recorded west of Selkirk Mountains.

Antennaria dioica, Gaertn.; Macoun, Cat. Can. Plants, Vol. I., pp. 236 and 548.

Charlton Island. James Bay, Hudson Bay, the var. parviflora, T. \& G. (Jas. M. Macoun.) Our herbarium material shows typical $A$. dioica, Gærtn., to be common from Assiniboia west through the Rocky Mountains to Kamloops, B.C., and north to Fort Smith on Great Slave River. The pink-flowered form is almost as common, but has not been found east of Belly River, Alberta.

Gnaphalium decurrens, Ives, var. Californicum, Gray'

In open woods at Revelstoke, B.C., and at Ainsworth, Kootanie Lake, B.C., 1890. (John Macoun.) New to Canada.

Gnaphalium microcephalum, Nutt.; Macoun, Cat. Can. Plants, Vol. I., p. 548.

Qualicum, Vancouver Island, and Protection Island, Nanaimo, V.I. Herb. No. 430. (John Macoun.)

Xanthium spinosum, L.

On ballast, Nanaimo, Vancouver Island. (John Macoun.) Recorded before only from Ontario.

RUDBECKIA HIRTA, L.

About deserted dwellings, Kicking Horse River, Rocky Mountains. (J. M. Macoun.) Revelstoke, B.C.; Griffin Lake, B.C. (John Macoun.) Not before recorded west of the prairie region. Probably introduced by means of the railway. 
Helianthus divaricatus, L.

Our specimens of this species show a wider range of cauline leaf forms than are included in Gray's descriptions. They vary from the ovate-lanceolate form, deeply and regularly serrate, to ovate with obtuse or rounded tips, with the serration barely apparent. Specimens collected at The Chats, Ottawa River, by Mr. Cowley, are farthest from typical divaricatus - the truncate, sessile, obtuse leaves, not being even divaricate.

Helianthus Rigidus, Desf.

In thickets, Revelstoke, B.C. (John Maconin.) Not before recorded west of prairie region. Probably introduced from the east along the Canadian Pacific Railway.

Bidens Cernua, I.

New Westminster, B.C. Herb. Nos. 457 and 458. (John Macoun.) Not before recorded west of Pocky Mountains.

Bidens Frondosa, L.

New Westminster, B.C. Herb. No. 456. (John Macoun.) Not before recorded west of Rocky Mountains.

Madia filipes, Gray; Macoun, Cat. Can. Plants, Vol. I., p. 248.

Nanaimo, Vancouver Island, Herb. No. 461; Deer Park, Lower Arrow Lake, Columbia River, B.C. (John Macoun.)

Artemisia AbSinthiom, L.

Waste places at Medicine Hat, Assa., 1895. (John Maconen, Herb. No. 10,980.) Not before recorded west of Ontario.

Artemisia Ludoviciana, Nutt.

Along roadsides at Port Arthur, Ont., 1889. (Dr. and Mrs. N. L. Britton and Miss Timmerman.) On the Cana- 
dian Pacific Railway, near the station at Chalk River, Ont. Herb. No. 10,985. (John Macoun.) Doubtless introduced from the west in both eases.

Senecio fastigiatus, Nutt.

S. megacephalus, Macoun, Cat. Can. Plants, Vol. I., p. 263.

Belly River, Alberta, 1881. (Dr. Geo. M. Dawson.) Souris Plain, Assa. (J. M. Macoun.) Indian Head, Assa. (David Macoun.) Alkaline flats, near Twelve-mile Lake, Wood Mountain, Assa., Herb. No. 11,615. (John Macoun.)

Senecio megacephalds, Nutt.

S. amplectans, Macoun, Cat. Can. Plants, Vol. I., p. 264. South Kootanie Pass, Rocky Mountains, 1881. (Dr. G. M. Dawson.) Amongst debris on mountain sides, Sheep Mountain, Waterton Lake, Lat. $49^{\circ} 05^{\prime}$, Rocky Mountains. Herb. No. 11,631. (John Macoun.) New to Canada.

\section{Cichorium intybus, L.}

Winnifred, Assa. (W.Spreadborough.) Sicamous, B.C. (John Macoun.) Not before recorded between Ontario and the Pacific Coast.

Stephanomeria Runcinata, Nutt.

S. minor, Macoun, Cat. Can. Plants, Vol: I., p. 284, in part.

On a dry clay bank, south of Wood Mountain, Assa., 1874. (Dr. G. M. Dawson.) Many Berries Creek, Milk River, Assa. (John Macoun.) New to Canada.

Asclepias purpurascens, L. ; Macoun, Cat. Can. Plants, Vol. I., p. 320.

Walpole Island, Lambton County, Ont. (C.K. Dodge.) 
Asclepias Sullivantit, Engelm.

Walpole Island, Lambton County, Ont. (C.K. Dodge.) New to Canada.

Gentiana puberula. Michx.

On the Humber Plains, near Toronto, Ont., 189.. $(W m$. Scott.) New to Canada. All the references under G. puberula, Macoun, Cat. Can. Plants, go to G. affinis, Griseb.

Lithospernity ANGestifolitem, Mx.

Sandy soil at the beach at Hamilton, Ont. ( $J . M$. Macoun.) Not before recorded east of Manitoba.

Orobanche ptrperea, Vill.

Found growing on a lawn at Wingham, Ont. ( $J \cdot A$. Morton.) Probably introduced in grass seed. New to Canada.

Itricllaria resupinata, B. W. Green; Can. Rec. of Science, Vol. VI., p. 204.

On an island near the north shore of Parry Sound, Lake Huron, 1893. (J. M. Dichson.) Only authentic record for Ontario.

Veronica Virgixtca, L.; Macoun, Cat. C'an. Plants, Vol. I., p. 360 .

Found by Prof. Macoun near Savanne station on the C. P. Railway, west of Port Arthur, in 1889. Probably introduced at this particular place, but indigenous further west along the railway. Credited to the Winnipeg Valley by Gray, but on what authority is not stated. Walpole Island, Lambton Co., Ont. (C. K. Dodge.)

Pedicularis scopolorum, Gray.

Summit of Saddle Mountain, Devil's Lake, Rocky 
Mountains, alt. 8,000 feet. (John Macoun.) New to Canada.

Prcnanthemum muticum; Pers.

Near Hamilton, Ont. (J.M. Dickson.) New to Canada.

Carex festiva, Dew., var. Haydeniana, W. Boott.

Borders of coulees, Cypress Hills, Assa., 1894. Herb. No. 7,397. (John Macoun.) Not before recorded east of Rocky Mountains.

Lycoponidm obscurum, L.; Macoun, Cat. Can. Plants, Vol. II., p. 288.

Near Fort Norman, Mackenzie River, 1892. (Miss E. Taylor.) Revelstoke, B.C., 1890. (John Macoun.) Not before recorded north or west of the Saskatchewan.

Lycoponium INUNDATUM. L.

Swamp at "The Lake," Stanley Park, Vancouver, B.C., 1893. Herb. No. 527 (John Macoun.) Not before recorded west of Ontario. 


Contributions from the Herbarium of the Geological Survey of Canada.

(By Permission of the Director.)

By Jayrs M. Macour, Cwrator of the Herbariun.

X.

Reprinted from the Canadian Recorl of Science, January, 189\%. 

"Reprinted from the Canadian Record of Science, January, 1897."

\section{Contributions to Canadian Botany.}

\section{By JaMes M. Macous.}

X.

Ranunculds Lapponicus, L.

Shore of Seal Lake, Northern Labrador, 1896. (A. $P$. Low:) Not before recorded east of Lake Nepigon, Ont.

Axemone Richardosoni, Hook.

Along the Ungava River, Labrador. (A.P. Lou:) Not before recorded from Labrador.

Berberis nervosa, Pursh.

Pend d'Oreille River, about 20 miles east of the Columbia River, B.C., 1896. (Jas. McEvoy.) Eastern limit. ${ }^{1}$

Nelcubium lutecy, Willd.; Macoun, Cat. Can. Plants, Vol. I, pp. 31 and 484 .

In abundance in Lake Erie at Port Rowan, Ont. (John Macoun, W. Scott, J. M. Dichson.)

The geographical limits given in these papers refer to Canada only. 
Nasturtium armoracta, Fries.

Old fields at Prince Albert, Saskatchewan. (John Macoun.) Not before recorded west of Ontario.

Cardamine digitata, Rich. in Frank. I. Journ., ed. 2 app. p. 26.

Near the mouth of the Mackenzie River, 1893. (Rev. J. D. Stringer.) Not rare between Lake Athabasca and Chesterfield Inlet. 1893. (J. W. Tyrrell.) Referred to $C$. pratensis by later American botanists. Easily separated from that species by its creeping, stoloniferous underground-stem, thinner, generally digitate leaves and smaller flowers. Not collected in America since first found by Richardson, but recorded from St. Lawrence Bay, Behring's Straits, by Chamisso and Eschscholtz. Fruiting specimens have never been collected.

Lobularia maritima, Desv.

Alyssum maritimum, Lam.

Near the outer wharf, Victoria, Vancouver Island. (John Macoun.) Probably established in other parts of Canada, but not before recorded.

Alyssum InCANum, DC.

Cultivated fields, Wallbridge, Hastings Co., Ont. (A. $Y$. Massey.) Not before recorded in Canada.

Thelopodium (?) salsugineum, Robinson, Syn. Fl. N. Amer., p. 175.

Sisymbrium salsugineum, Pall.; Macoun, Cat. Can. Plants, Vol. I., p. 47.

By a saline lake, Park-beg, west of Moose Jaw, Assiniboia, June 23rd, 1896. (John Macoun. Herb. No. 
14, 292). ${ }^{1} \quad$ This interesting little Crucifer has been rarely collected, and there is still some uncertainty as to its true place among the Cruciferæ. It has already been referred to several genera, and Dr. Robinson has only doubtfully named it Thelopodium. He says: "The problematic S. salsugineum, Pall. with glabrous entire cordate-clasping leaves, purplish flowers and undivided stigma, may well be referred to Thelopodium, from which it appears to be distinguished only by its small size and slender habit." (Syn. Flora, p. 137). Its range in America, according to Dr. Robinson, is "Rocky Mountains from Colorado at South Park, Porter, to British America and shores of the Aretic Sea, Richardson, according to Hooker, 1.c." but it has never been found in our Rocky Mountains so far as we know.

Capselua kldiptica, C. A. Meyer.

C. divaricata, Walp.; Macoun, Cat. Can. Plants, Vol. I., p. 56 ; Can. Rec. Science, Nov., 1894, p. 147.

Damp places near a saline lake, Park-beg, Assa., 1896. (John Macoun. Herb. No. 12,390.) Not before recorded between Labrador and British Columbia.

VIOLA ROTUNDIFolia, Mx.

Moose Creek, Can. Atlantic Ry. ; Jordan, Welland Co., Ont. (John Macoun.) Niagara Falls, Ont. (R. Cameron.) 20-mile Creek, west of St. Catharines, Ont. ( $J$. Dearness.) Not before recorded from Ontario.

Arenaria macrophylla, Hook.

Dr. Robinson in Proc. Amer. Acad. of Arts and Sciences, Vol. XXIX., p. 290, gires as the range of this species "eastward to Isle St. Ignace, Lake Superior."

1 Whenever herbarium numbers are given, they are the numbers under which specimens have been distributed from the herbarinn of the Geological Survey of Canada. 
Specimens collected in 1894 by Mr. A. P. Low at Lake Michikamow, Labrador, and in 1896 along the Koaksoak River, Northern Labrador, have been doubtfully referred here.

Sagina Nivalis, Lightf.

Along the Ungava River, Northern Labrador, 1896. (A. P. Low.) New to Canada.

\section{Hypericum PROLIFICUM, L.}

Sandy plains, along fence rows and in woods Caradoc township south of Strathroy, Ont., Aug., 1888. (J. Dearness.) New to. Canada.

Hypericum nudicaule, Walt.

H. Sarothra, Mx. ; Macoun, Cat. Can. Plants, Vol. I., p. 85. Sandy fields south of Sandwich, Ont., 1892. (John Macoun.) Only authentic Canadian record.

Geranidu Bicknellir, N. L. Britton, Bull. Torr. Bot. Club, Vol. 24, p. 92.

"Similar to G. Carolinianum, but taller, the stems usually more slender, loosely pubescent. Leaves slenderpetioled, somewhat angulate in outline, the segments oblong or linear-oblong, mostly narrower; peduncles slender, two-flowered, the inflorescence loose; sepals lanceolate, awn-pointed; ovary lobes pubescent ; persistent filaments longer than the carpels; beak about $1^{\prime}$ line long, long-pointed, its tip 2 "-3" long; seeds reticulated."

"Nova Scotia (?) Maine to Western Ontario and Southern New York."

In the February number of the Bulletin of the Torrey Botanical Club, Dr. Britton describes G. Bicknellii as one of "two undescribed eastern species." Our herbariun sheets of G. Carolinianum have long been separated 
into two forms, both of general distribution from Ontario westward. Our herbarium specimens of $G$. Bicknellii give this plant a much wider range than is indicated by Dr. Britton. They are from Bedford, N.S.; Nepigon, Lake Superior; Killarney, Man.; Prince Albert, Saskatchewan; Banff, Rocky Mountains; Ainsworth, Kootanie Lake, B.C.; Spence's Bridge, B.C. (John Macoun.) Ottawa, Ont. ; Observation Point, Lake Winnipeg. (J.M. Macoun.) North Shore of Lake Athabasca. (J.W. Tyrrell.) Arctic North America. (Dr. Richardson.) All the specimens from the above localities are separable at a glance from true $G$. Carolinianum by the much longer and very slender tip of the beak.

The specimens from Kootanie Lake were found growing with $G$. Carolinianum and were named var. longipes, Wat., a variety that must approach very closely G. Bicknellii.

\section{Gerantum Carolinianum, L。}

Not represented in the herbarium of the Geological Survey from eastern provinces. Belleville, Ont. ; Cypress Hills, Assa.; Sproat, Columbia River, B.C.; Ainsworth, Kootanie Lake, B.C.; Mt. Finlayson, Victoria Arm, and Comox, Vancouver Island. (John Macoun.) Walpole Island, Lambton Co., Ont. (C. K. Dodge.)

We have no intermediate forms between $G$. Bicknellii and G. Carolinianum.

Lupinus hitToralis, Dougl.

Sandy soil at Point Holmes near Comox, Vancouver Island, 1893. (John Macoun.) New to Canada.

Amorpha fruticosa, L. ; Macoun, Cat. Can. Plants, Vol. I, p. 109.

In thickets by the Red River at Morris, Man., and at 
River Park, Winnipeg, Man., 1896. (John Macoun. Herb. No. 12511.) Not reported since found by Douglas.

Desmonium Canadense, DC.

In thickets at Morden, Man., 1896. (John Macoun. Herb. No. 12525.) Western limit.

Desmodium Illinoense, Gray.

Komoka, Ont., 1888. (J. Dearness.) New to Canada.

LATHYRUS LITTORALIS, Endl.

Ahousset, west coast of Vancouver Island. (J. $R$. Anderson.) New to Canada.

Vicia hirsuta, Koch.

In cultivated fields, Olds, Alberta. (T. N. Willing.) Not before recorded from prairie region.

Amphicarpa monotca, Ell.

In thickets near the Assiniboine River at Brandon, Man.; thickets by the Red River, Winnipeg, Man., 1896. (John Macoun.) Not before recorded west of Lake Superior.

SAXifraga REFleXA, Hook.

Near the mouth of the Mackenzie River, 1893. (Rev. J. D. Stringer.) The reflexed calyx-segments, the two orange spots on the petals and the petaloid filaments are conspicuous characters of the fine specimens collected by Mr. Stringer. Herb. No. 14300.

Parnassia Caroliniana, Mx.

Boggy places near Stony Mountain, Man., 1896. (John Macoun. Herb. No. 12660.) Western limit in Canada. 
Drosera intermedia, Hayne, var. Americaya, DC:

In a muskeg north of Prince Albert, Saskatchewan, 1896. (John Macoun. Herb. No. 12669.) Western and northern limit.

Drosera innearis, Goldie.

In a muskeg north of Prince Albert, Saskatchewan, 1896. (John Macoun. Herb. No. 12668.) Not before recorded between Manitoba and Rocky Mountains.

LCDwigia polycarpa, Short \& Peter.

First recorded from Canada in Part I. of these papers. Since collected by Mr. J. Dearness near Comber, Ont., and by Mr. C. K. Dodge near Sarnia, Ont.

Lonicera glaccescexs, Rydberg, Bull. Torr. Bot. Club, Vol. XXIV., p. 90.

L. Sullivantii, Macoun, Cat. Can. Plants, Vol. I., pp. 197,539 .

L. glauca, Macoun, Cat. Can. Plants, Vol. I., p. 197, in part, and Vol. I., p. 539.

L. hirsuta glaucescens, Rydberg, Contr. U. S. Nat. Herb. III., 503.

From North-Western Ontario to the Rocky Mountains. Our herbarium specimens are from Manitoba House, Lake Manitoba; Fort Ellice, Assiniboine Piver, Man.; West Selkirk, Man. Herb. No. 12805 ; Rat River, Otterburne, Man.; Brandon, Man. Herb. No. 12804; Moose Jaw, Assa. Herb. No. 12803; Prince Albert, Saskatchewan, Herb. No. 12806 ; Banff and Kananaskis, Rocky Mountains; Waterton Lake, South Kootanie Pass, Rocky Mountains. Herb. No. 10802. (John Macoun.) Doghead, Lake Winnipeg. (J. M. Macoun.) Indian Head, Assa. (W. Spreadborough.) Milk River Ridge, Alta. (Dr. G.M. Dawson.) Red Deer River, Alta. (H. H. G(cetz) Fort 
Smith, Great Slave River. (Miss E. Taylor.) Additional Canadian localities given by Mr. Rydberg are River That Turns, Assa. (John Macoun.) Ontario (Dr. and Mrs. Britton and Miss Timmerman; T. J. W. Burgess.) Saskatchewan. (E. Bourgeau.)

LIATRIS SCARIOSA, Willd.

Since the publication of No. 9 of these papers, Dr. T. J.'W. Burgess has written me that he collected this species at Leamington, Ont., in 1886, and Mr. J. Dearness reports it from Port Frank and PointEdward, Ont.

LIATRIS SPICATA, Willd.

Leamington, Ont. (Dr.T.J.W. Burgess.) The only other Canadian locality known to us is the vicinity of Sarnia, Ont., where this species is common.

Rodbeckia columnaris, Pursh, var. Pulcherrima, Torr. \& Gray; Macoun, Cat. Can. Plants, Vol. I., p. 243.

Near the Government Experimental Farm, Brandon, Man., 1896. (John Macoun. Herb. No. 12243.) The dark brown-purple rays of this beautiful plant separate it from $R$. columnaris.

BARIA MARITIMA, Gray.

On Bird Island, Barclay Sound, west coast of Vancouver Island. (Chas. F. Newcombe.) New to Canada. Only other known place of occurrence, Farallones Islands, off San Francisco.

ANTHEMIS ARVENSIS, L.

On ballast at Nanaimo, Vancouver Island, 1887. (John Macoun.) Common around Victoria, Vancouver Island. (J. R. Anderson.) Not before recorded west of the Maritime Provinces. 
Chrysanthemem arcticum, L.

Shore of Larcomb Island, Observatory Inlet, B.C. (J. McEvoy.) Southern limit on Pacific Coast.

Chrysanthemom Parthenicy, Pers.

On ballast heaps, Nanaimo, Vaneouver Island, 1893. (John Macoun.) Not before recorded west of Ontario.

Artemisia glatca, Pall.; Macoun, Cat. Can. Plants, Vol. I., p. 25̃5, and Vol. II., p. 335.

Common in Manitoba from Brandon southward. (John Macoun. Herb. Nos. 12257 and 12426.)

Artemisia yorvegica, Fries, var. Pacifica, Gray.

Mount O.K., near Alaskan boundary, B.C. (H. W. E. Canoran.) Yukon River. (W. Ogilvie.)

ARTEMISIA VULGaris, L.

Along the C. P. Ry. at Brandon, Man.; waste places, Sicamous, B.C. ; ballast heaps, Nanaimo, Vancouver Island. (John Macoun.) Not recorded west of Ontario.

Artemisia volgaris, L. var. Califorita, Bess.

Specimens collected by Mr. Jas. Fletcher near Victoria, Vaneouver Island, in 1883, were doubtfully referred here by Prof. Macoun. (Cat. Can. Plants, Vol. I., p. 258.) It has since been collected at Burrard Inlet, B.C., and at Sooke, Saanich Arm, and Qualicum, Vancouver Island, by Prof. Macoun.

Petasttes palmata, Gray.

Revelstoke, Columbia River, B.C.; Port Moody, B.C. ; Comox, Sooke and Victoria, Vancouver Island. (John Macoun.) Nanaimo River, Vancouver Island. ( $J . R$. Anderson.) Not before recorded west of the Selkirk Mountains. 
Cnicus altissimus, Willd, var. Discolor, Gray.

In thickets, River Park, Winnipeg, Man. (John Macoun. Herb. No. 12292.) Not before recorded west of Sarnia, Ont.

CNicus Edulis, Gray.

Thickets, Sicamous, Shuswap Lake, B.C., and Ainsworth, Kootanie Lake, B.C. (John Macoun.) Not before recorded from interior of British Columbia.

ONOPORDON ACANTHIUM, L.

Waste grounds, Nanaimo, Vancouver Island, 1887. (John Macoun.) Not before recorded west of Ontario.

Centaurea cyanus, $\mathrm{L}$.

Waste places, Kootanie Lake, B.C. (Dr. G. $M$. Dawson.) Goldstream, Vancouver Island. (John Macoun.). Not before recorded west of Ontario.

Calendula arvensis, L.

On ballast, St. John, N.B. (G. U. Hay.) New to Canada.

ECHINOPS GLOBIFER, Janka.

Escaped from cultivation and well established at Beeton, Ont. (J. M. Dickson.)

LAMPSANA COMMUNIS, $\mathrm{L}$.

North Saanich, Vancouver Island. (J. R. Anderson.) Roadsides, Comox and Victoria, Vancouver Island. (John Macoun.) Not before recorded from Vancouver Island.

Crepis occidentalis, Nutt. var. Glandulosa, Torr.; Macoun, Cat. Can. Plants, Vol, I., p. 556.

Prairies, Farewell Creek, Cypress Hills, Assa. (John Macoun. Herb. No. 11709.) Eastern limit. 
Hieraciom gracile, Hook.

Mount Mark, Vancouver Island. Alt. 3,000 ft. (John Macoun.) Not before recorded from Vancouver Island. New stations for this species from interior of British Columbia are Queest Creek, Shuswap Lake, alt. 5,000 ft.; mountains north of Griffin Lake, alt. 6,000 ft.; Toad Mountain, Kootanie Lake, alt. 6,000 ft. (J. M. Macoun.)

Hieracium aurantiacci, L. ; Macoun, Cat. Can. Plants, Vol. I., p. 557, and Vol. II., p. 336.

Since first collected at London by Mr. Dearness and near Lake Magog, Que., by Mr. Giroux in 1889, this plant has become a troublesome weed in parts of Quebec and Ontario. Our herbarium specimens are from Lake Memphremagog, Que. (Dr. Ells.) Mer Bleue, near Ottawa, Ont. (Dr. Jas. Fletcher.) Port Colborne, Ont. (John Macoun.)

\section{Lactuca Canadensis, L.}

Damp thickets, Sicamous, and Revelstoke, B.C. (John Macoun.) Not before recorded from west of prairie region. Prof. Macoun (Cat. Can. Plants, Vol. I., p. 280) says that this species is quite common in thickets in the western prairie region, but our only herbarium specimens from the prairie were collected at Morden, Man., by Prof. Macoun in 1896. L. leucophcea, Gray, is common throughout the prairie region.

\section{LACTuca HIRSUTA, Muhl.}

Alluvial soil near the Pembina River, three miles north of Killarney, Man., 1896. (John Macoun. Herb. No. 12346.) Not before recorded west of Ontario. Sandy woods near Ottawa and thickets west of Leamington (John Macoun) are new stations for Ontario. 
Lactuca ledcophea, Gray; Macoun, Cat. Can. Plants, Vol. I, pp. 281, 559.

Additional western stations for this species are Sicamous, B.C.; Revelstoke, B.C.; Stanley Park, Vancouver, B.C., and Qualicum, Vancouver Island. (John Macoun.)

Prenanthes atata, Gray; Macoun, Cat. Can. Plants, Vol. I., p. 283.

Shake River, Burrough Bay, Lat. $56^{\circ}$ near Alaskan boundary. (H. W. E. Canavan.) Alberni Canal and Barclay Sound, Vancouver Island. (John Macoun.) Not rare on the west coast of Vancouver Island, collected at Muir Creek and Port San Juan. (I. R. Anderson.)

Prenanthes racemosa, Michx var. pinnatifida, Gray.

Near Windsor, Ont. ( $W m$. Scott.) Walpole Island, Lambton Co., Ont. (C.K. Dodge.) New to Canada.

Sonchus ARVENsis, L.

In the C. P. Ry. station yard at Brandon, Man. (John Macoun.) Not before recorded west of Ontario.

TrAgOPOGON PORRIFOLIUS, L.

Waste places, Spence's Bridge, B.C. (John Macoun.) Not before recorded between Ontario and Vancouver Island.

Lobelia Dortmanna, I.

Shawnigan Lake, Vancouver Island. (John Macoun.) Not before recorded from any part of British Columbia.

Vaccinium Canadense, Kalm. ; Macoun, Cat. Can. Plants, Vol. I., pp. 290 and 560.

Revelstoke, B.C., and Craigellachie, B.C. (John Macoun.) Western limit. 
VACCINICM Ovalifolidu, Smith.

Revelstoke, B.C.; Ainsworth, Kootanie Lake, B.C.: Sicamous, B.C.; Comox and Mount Mark, Tancouver Island. (John Macoun.) Head of Bennett Lake, Lat. 61', north of B.C. (Dr. G. M. Dauson.) Quesnel Lake, B.C. (A.Bouman.) Mount Chean, B.C. (J.R.Anderson.) Not before recorded in Canada west of the Selkirk Mountains, but evidently common throughout British Columbia.

Arctostaphylos alpina, Spreng.; Macoun, Cat. Can. Plants, Vol. I., p. 294.

Cross Portage, sepawisk Lake, Nelson River, Kewatin, 1896. (Jos. Tyrrell.) Southern limit in Central Canada.

Chiogenes hispidula, T. \& G.

Mossy woods, Sicamous, B.C. (John Macoun.) Western limit in Canada.

Gaultheria ovatifolia, Gray.

In woods at Revelstoke, Columbia River, B.C. (John Macoun.) Fastern limit in Canada.

Gaultheria Myrsinites, Hook.

Alpine summits, Ainsworth, Kootanie Lake, B.C., and north of Griffin Lake, B.C. (John Macoun.) Western limit in Canada.

Ledem glandulosum, Nutt. ; Macoun, Cat. Can. Plants, Vol. I., p. 562 and Vol. II.,p. 339.

Additional stations for this species are Mount Aylmer, Devil's Lake, Rocky Mountains, alt. 6,000 ft., 1891. (John Macoun.) Mountains west of Okanagan Lake, B.C. (Jas. McEroy.) Mr. McEroy reports this to be common at between 5,000 and $6,000 \mathrm{ft}$. altitude on most of the 
mountains between Nicola River and Lake Okanagan, B.C. In the Rocky. Mountains it seems confined to the vicinity of the Bow River.

RHODODENDRON ALBIFLORUM, Hook.

Additional stations for this species are Queest Creek, Shuswap Lake, B.C., alt. 5,000 ft.; mountains north of Griffin Lake, B.C., alt. 5,000 ft.; mountain woods, Ainsworth, Kootanie Lake, B.C. (Jas. M. Macon n.) Mountains south of Tulameen River, B.C., alt. 5,000 ft. (Dr. G. M. Dawson.) Alpine woods, Mount Arrowsmith, Vancouver Island. (John Macoun.) Not before recorded from Vancouver Island.

Monotropa uniflora, L.; Macoun, Cat. Can. Plants, Vol. I., p. 307.

Not recorded by Prof. Macoun west of Lake of the Woods. Norway House, Lake Winnipeg. (Dr. Richardson.) Great Slave River. (Miss E. Taylor.) Sicamous, B.C.; between Qualicum and Alberni, Vancouver Island. (John Macoun.)

Pterospora andromeda, Nutt.; Macoun, Cat. Can. Plants, Vol. I., p. 307.

Not recorded by Prof. Macoun, east of Quebec or west of the Saskatchewan. Pine woods, Prospect Creek, Prince Edward Island; Nanaimo, Vancouver Island. (John Macoun.) Mountains west of Lake Okanagan, B.C. (Jas. McEvoy.)

Trientalis Americana, Pursh.

In thickets north of Prince Albert, Sask. (John Macoun.) J3lack River, east of Lake Athabasca. (J. W. Tyrrell.) Northern and western limits in Canada. 
Dodglasta arctica, Hook.

A few specimens of this beautiful little plant were collected along the coast between the mouth of the Mackenzie Piver and Herschel Island by Rev. J. D. Stringer, May 25th, 1893. It has not been found since collected by Dr. Richardson to the east of the Mackenzie River. Herb. No. 14298.

ANagalits arvensis, I.

In waste places and on ballast heaps, Nanaimo, Vancouver Island. (John Macoun.) Not before recorded west of Ontario.

Fraxinus viridis, Michx.

South of Moose Jaw, Assa., 1896, and Old Wives Lakes, Assa., 1895. (John Macoun.) Western limit in Canada.

VINCETOXICU'M Nigrum, Monch.

In cultivated grounds, Victoria, Vancouver Island, 1888. Adventitious. (Dr. Jas. Fletcher.) Only Canadian record.

Gevtiana Andrewsil, Griseb.

Rich moist ground, Selkirk, Man. (Jas. M. Macoun.) Griswold, Man. (Rev. W. A. Burman.) Western limit in Canada.

PhLox Hookeri, Dougl.

Gilia pungens, var. Hookeri, Gray, Syn. Fl., p. 141.

Kettle River, east of Okanagan Lake, B.C. (J. $R$. Anderson.) New to Canada. First found by Douglas on Okanagan River a little south of the international boundary.

Collomia grandiflora, Dougl.

Dry, rocky banks, Botanie Creek, near Lytton, B.C. (Jas. McEroy.) Easteru limit in Canada. 
Gilia liniflora, Benth. var. PHarmaceoides, Gr.

Depressions on the prairie, Police Point, Medicine Hat, Assa., and near Cypress Lake, Assa. Herb. No. 5546. (John Macoun.) Not before recorded east of British Columbia.

Phacelia tanacetifolia, Benth.

A weed on the Experimental Farm, Brandon, Man., 1896. (John Macoun.) New to Canada.

Cynoglossum officinale, L.

Along an old road near the railway bridge, Brandon, Man., 1896. (John Macoun.) Not before recorded west. of Ontario.

Physalis Philadelphica, Lam.

In a ravine, S.W. of Komoka, Ont. (J.Dearness.) New to Canada.

Physalis Virginiana, Mill. var. ambigua, Gray; Macoun, Cat. Can. Plants, Vol. I., p. 350.

Sandy hillside, shore of Lake Huron, Sept., 1891.

Dearness.) Not before recorded from Ontario, though some of the references under P. Virginiana, Macoun, Cat. Can. Plants, Vol. I. p. 350 , are probably this variety.

Gratiola Virginiana, L. ; Macoun, Cat. Can. Plants, p. 359.

Comox, Vancouver Island, 1893. (John Macoun. Herb. No. 706.) Distributed as G. ebracteata. Credited by Gray to British Columbia, but not before found by Canadian collectors.

Martynia proboscidea, Glox.

Niagara Falls, Ont., 1892. (R. Cameron.) Hamilton, Ont. (J. MT. Dickson.) Not known to ocuur elsewhere in Canada. 
Phryma Leptostachya, L.

Damp thickets by a brook at Morden, Man. (John Macoun. Herb. No. 12431.) Not recorded west of Ontario.

Tedcriom Canadense, L.; Macoun, Cat. Can. Plants, Vol. I., p. 380 in part, and Vol. II., p. 349.

Apparently much rarer than $T$. occidentale even in Ontario. Our herbarium specimens are from Pt. Pelee, Essex Co., Ont. (Dr. Burgess.) Brampton, Ont. (Jas. White.) In thickets by the Assiniboine River at Brandon, Man. (John Macoun. Herb. No. 12416.) Not before recorded west of Ontario.

Teccrily occidextale, Gray; Macoun, Cat. Can. Plants, Vol. I., p. 574 and Vol. II., p. 349.

Our herbarium specimens are from Ottawa, Ont.; Belleville, Ont.; Bird's Hill, near Winnipeg, Man. Herb. No. 12288 : Cypress Lake, Cypress Hills, Assa. Herb. No. 12890 ; Kamloops, B.C. (John Macoun.) London, Ont. (Dr. Burgess.) Burlington Beach, Hamilton, Ont. (J. M. Dickson.) Not before recorded from the prairie region.

Abronia merantha, Choiss.

Abundant in dry sand at the crossing of Many Berries Creek, north of Milk River, Assa., July 9th, 1895. (John Macoun. Herb. No. 12902.) New to Canada.

A.rтchla Dichotoma, Mx.; Macoun, Cat. Can. Plants, Vol. I., p. 396.

Near Leamington, Ont., 1890. (J. Dearness.) San dy fields near Leamington, Ont., 1892. (John Macoun.) Only once before collected in Canada. 
Axyris amarantoides, L.; Macoun, Cat. Can. Plants, Vol. II., p. 352 .

First collected in 1886, in Manitoba, by Dr. Fletcher, now common along the line of the Can. Pac. Ry. west to Medicine Hat, Assa., and in cultivated fields and waste places throughout Manitoba. Our herbarium specimens are from Winnipeg and Brandon, Man.; Indian Head, Moose Jaw and Medicine Hat, Assa.

Erigonum umbellatum, Torr. ; Macoun, Cat. Can. Plants, Vol. I., p. 406.

Additional stations for this species are Milk River Ridge, Alta.; Vermillion Mountain near Banff, Rocky Mountains; Lake Louise, Rocky Mountains; Sproat, Columbia River, B.C. (John Macoun.) Big Horn Mountains, west of Lake Okanagan, B.C. (Jas. McEvoy.) Not before recorded east of Rocky Mountains.

ERigondm heracloides, Michx.

Deer Park, Lower Arrow Lake, B.C. (John Macoun.) Eastern limit in Canada.

Erigonum ovalifolium, Nutt. ; Macoun, Cat. Can. Plants; Vol. I., p. 407.

Big Horn Mountains, west of Okanagan Lake, B.C. (Jas. McEvoy.) Along Waterton Lake and on Sheep Mountain, South Kootanie Pass, Rocky Mountains. (John Macoun. Herb. No. 12948.)

Erigonum multiceps, Nees; Macoun, Cat. Can. Plants, Vol. I., p. 407.

Wood Mountain, Assa. Herb. No. 12949; dry rocks along Waterton Lake, South Kootanie Pass, Rocky Mountains, 1895. (John Macoun.) Eastern limit in Canada. 
- Erigonom niveum, Dougl.

Dry ground, Lake Okanagan, B.C., Sept. 15th, 1890. (Dr. G. M. Dauson.) New to Canada.

ERigondm cérnudu, Nutt.

Sand hills at the crossing of Many Berries Creek near Milk River, Assa. Herb. No. 12947; on the banks of the South Saskatchewan at Police Point, Medieine Hat, Assa. Herb. No. 12946. (John Macoun.) New to Canada.

Polygonum-bistortoides, Pursh.

On the summit of Sheep Mountain, Waterton Lake, Rocky Mountains, alt. 7,500 ft., July 31st, 1895. Herb. No. 12989. (John Macoun.) New to Canada. Aretic American specimens referred to $P$. Bistorta seem to be intermediate between that species and $P$. bistortoides.

Sassafras OfFicinale, Nees.

Near Sarnia, Lambton Co., Ont. (C. K. Dodge.) Northwestern limit in Ontario.

QURRCUS ALBA, L.

Elevated shore of Rainy Lake,.Ont., 1896. (W. McInnes.) Western limit in Canada.

Cypripedium acaule, Ait.; Macoun, Cat. Can. Plants, Vol. II., p. 22.

Dry hillock of sand and boulders. Lat. $57^{\circ} 30^{\prime}$, Long. 107 . (Jas. W. Tyrell.)

Urularia perfoliata, L.; Macoun, Cat. Can. Plants, Vol. II., p. 44.

Near Niagara, Ont., 1890. (J. Dearness.) Jordan Station, near Niagara, Ont., 1892. (John Macoun.) Very rare and not collected for many years. 
Aletris farinosa, L. ; Macoun, Cat. Can. Plants, Vol. II., p. 23.

Common at Sandwich, Ont. (John Macoun.) Near Sarnia, Lambton Co., Ont. (C. K. Dodge. J. Dearness.) Only recorded before from Leamington, Ont.

Erythronium albidum, Nutt.; Macoun, Cat. Can. Plants, Vol. II., p. 41.

Stag Island in St. Clair River, 5 miles below Sarnia, Ont. (C. K. Dodge.) North-western limit.

SCIRPUS CAMPESTRIS, Britton.

S. mavitimus, Macoun, Cat. Can., Vol. II., p. 100 in part.

Common throughout the prairie region. Our herbarium specimens are from Red River, Man. (Douglas.) File Hills, Assa.; Thunder Creek, Moose Jaw, Assa.; Park Beg, Assa. Herb. No. 16411; Milk River, Alberta. Herb. No. 16412. (John Macoun.)

ScIRpus Smithit, A. Gray.

In wet sand, Toronto Island, Ont., 1886. ( $W m$. Scott.) New to Canada.

Scirpus Debilis, Pursh.

Muddy places, Queenston Heights, Ont., 1896. ( $W m$. Scott.) New to Canada.

Firmbristylis castanea (Michx.), Vahl.

Walpole Island, Lambton Co., Ont., 1894. (C. K. Dodge.) New to Canada.

Eleocharis motata (L.), R. \& G.

E. quadrangulata, R. \& S.

Sarnia Bay, near Sarnia, Ont., 1896. (C. K. Dodge.) New to Canada. 

Contributions from the Herbarium of the Geological Survey of Canada.

(By Permission of the Director.)

By Jaxizs M. Macoer,

Curator of the Herbarium.

XI.

Reprinted from the Canadian Record of Science, October, 189;. 

"Reprinted from the Canadian Record of Science, October, 1897."

\title{
Contributions to Canadian Botany.
}

\author{
By JAMRS M. MacoUN.
}

\section{XI.}

Nesodraba megalocarpa, Greene, Pittonia, Vol. III., p. 253.

Central tuft of three leaves 3 inches high or more; leaves oblong-spatulate, obtuse, with a few coarse teeth near the summit; stout ascending peduncles 6 inches high, clothed below the raceme with oval sessile leaves $\frac{3}{4}$ inch long; pods linear-oblong, $\frac{1}{2}$ to $\frac{3}{4}$ inch long, two or three lines wide, acutish, and tipped with an acute style.

Seal Rocks, Dawson Harbour, Skidegate Inlet, Queen Charlotte Islands, B.C., 1897. Herb. No. 16,928. (Dr. C. F. Newcombe.)

Dr. Greene's new genus, Nesollraba, includes three species, one of which, $N$. grandis, has long been a puzzle to botanists, having been by the earlier botanists referred to Cochlearia and by the later, with less reason, to Draba. V. megalocarpa is known only from Dr. Newcombe's specimens. N. grandis is common in herbaria as Draba hyperborea.

Polygala Sexega, L, var. Latifolia, T. \& G.

Dry bank, Valley Inn near Hamilton, Ont., 1896, (J.M. Dickson.) Only other known Canadian station. Georgian Bay.

C'erastium artexse, L., var. villoscy, Holl. \& Britt.

In sod and along old paths near the cemetery at Hamilton, Ont., 1897. (J.M. Dickson.) New to Canada.

SAGINA PROCUMBENS, L.

Growing in Mr. R. Cameron's yard at Niagara, Ont. 
Probably indigenous, though not before recorded from Ontario.

Trifolium dianthom, Greene, Pittonia, Vol. III., p. 217.

Very dwarf perennial, the rather stoutish stems, scarcely an inch long, surpassed by the upper petioles and peduncles; herbage deep green and very glabrous; leaflets obcordate or obovate, about $\frac{1}{4}$ inch long, rather sharply and mucronately dentate; peduncles shorter than the leaves, bearing an involucrate pair of purple flowers; involucre large for the plant, lacerately cleft; calyx with 10 -nerved tube shorter than the teeth, these with oblonglanceolate body tapering to a stoutish aristiform apex; corolla twice the length of the calyx, the petals purple, tipped with white.

Species founded on specimens collected at Esquimault near Victoria, Vancouver Island, by Prof. Macoun, May 13th, 1893. Herb. No. 97, and distributed as T. pauciflorum. Specimens collected at the same place by Prof. Macoun in 1875, and labelled T. pauciflorum var. (Herb. No. 18,015), are this species.

Trifolium agrarium, L.

New Westminster, B.C. (A. J. Hill.) Not recorded west of Ontario.

Prunus mahalei, $\mathrm{L}$.

Mountain side at Hamilton, Ont., May 15th, 1895. (J. M. Dickson.) Well naturalized. Not before recorded from Canada.

Aster angustus, T. \& G.

Growing in railway round-house at Montrose, Ont. (R. Cameron.) Introduced from the west along railway.

Erigeron Macouni, Greene, Pittonia, Vol. III., p. 162.

Low perennial, with a stout branching caudex bearing 
many spatulate, linear, acute, entire leaves, and stoutish ascending, sparsely leafy monocephalous peduncles; the rounger foliage canescently strigose, the older glabrate; heals large, hemispherical; bracts of the somewhat hoarytomentose involucre subequal, in two series; rays about 50 , rather broad, purple.

Summit of Sheep Mountain, Waterton Lake, Rocky Mountains, alt., 7,500 ft., July 31st, 1895. Herb. No. 10,S58. (John Macoun.) Distributed as Erigeron ochroleucus.

Erigerox kindbergi, Greene, Pittonia, Vol. III., p. 165.

Stems several, erect, from a perennial root, 6 inches high, pilose-pubescent, apparently flaccid and not conspicuously angled; lowest leares oblanceolate, entire, acute, wholly glabrous and, in no degree, ciliate; the cauline narrowly linear, elongated, sessile by an abruptly dilated base; heads mostly solitary, small, the involucre barely three lines high; bracts very unequal, all narrowly linear and rather abruptly acute, glabrous and glandless, except at the pilose-pubescent base; rays very numerous, narrow and short; pappus scanty for the $E$. acris group, and not at all accrescent, dull-white, unchanged in age.

Meadows on the plateau east of Stump Lake, B.C., July 14th, 1891. Herb. No. 7,793. (Jas. McEroy.) Named for Dr. Nils Conrad Kindberg, by whom some of the characters were indicated in 1892.

Erigeron Juccndts, Greene, Pittonia, Vol. III., p. 165.

E. acris, Macoun, Cat. Can. Plants, Vol. I., p. 5̃ 7 in part. E. acris, var. Drobachensis, Macoun, Cat. Can. Plants, Vol. I., p. 547 in part.

E. alpinus, Macoun, Cat. Can. Plants, Vol. I., p. 234 in part.

Perennial, 2 to 10 inches high, the several stems monocephalous, or in larger plants with several and corymbose- 
racemose rather large heads; herbage, light-green and flaccid, more or less pilose-pubescent, and at least the upper parts of the plant glandular-viscid; lowest leaves spatulate-ovate and oblanceolate, obtuse, mucronulate, entire, or with one or two pairs of crenate and mucronulate teeth below the apex, both faces sparsely pubescent and the petioles as sparsely ciliate; the cauline oblonglanceolate, entire; heads three or four lines high, but involucral bracts notably shorter than the Howers, unequal, nearly linear, the inner acuminate, the tips of all more or less spreading, the whole involucre as well as the peduncles viscid-glandular, the basal parts hirsutepubescent; rays apparently 60 to 80 , not extremely narrow ; pappus, copious and accrescent, dull white, little darker in age.

Distributed freely from the Herbarium of the Geological Survey of Canada as E. acris, E. acris, var. Drobachensis and $E$.alpinus, to which species it was at various times referred by Dr. Gray and Dr. Watson. Easily distinguished from $E$. Drobachensis by its very different habit, pubescence and inflorescence ; and the pappus of the latter, at least in the Arrerican plant, becomes of a rich and beautiful brown-red in age. The peduncles in the present species, though slender, are abruptly and conspicuously enlarged at summit under the involucre.

Summit of Sheep Mountain, Waterton Lake, Rocky Mountains, alt., 7,000 ft. Herb. No. 10,841; Lake Louise, Rocky Mts., alt., 6,500 ft. Herb. No. 7,794; Kicking Horse Lake, Rocky Mts., alt., 7,000 ft. Herb. No, 18,010; Roger's Pass, Selkirk Mountains, alt., 5,000 ft. Herb. No. 11,005 ; Revelstoke, B.C. Herb. No. 18,011. (John Macoun.) Western summit of North Kootanie Pass, Rocky Mountains. Herb. No. 18,012. (Dr. G. M. Dawson.) Mount Queest, Shuswap Lake, B.C., alt., 6,000 ft. Herb. No. 11,009. (Jas. M. Macoun.) Dr. Kindberg was of the opinion that the Lake Louise plant agreed very nearly 
with $E$. politus Fr., but $E$. politus is not only glabrous, but it has none of the riscid-glandulosity which is so characteristic of $E$. jucundus.

Erigeror elatcs, Greene, Pittonia, Tol. III., p. 164.

E. alpinus, var. clatus, Hook. : Macoun, Cat. Can. Plants in part.

Collected by Drummond in the Rocky Mountains, Lat. $54-56^{\circ}$. re-discorered by Prof. Macoun in 1890. Kicking Horse Lake, Rocky Mountains. Herb. No. 18,014; Cave Arenue, Banft, Rocky Mountains. Herb. No. 11,018. (John Macoun.)

\section{Erigeron alpints, L.}

The specimens, collected by Dr. Dawson and referred here by Prof. Macoun in Cat. Can. Plants, Vol. I., p. 234, are $E$. jucundus. Our only specimens of $E$. alpinus were collected by Prof. Macoun at Kicking Horse Lake, Rocky Mountains, in 1885 , when ther were referred to $E$. acris.

Ericierox peregrists (Pursh), Greene, var. Dawsoni, Greene, Pittonia, Vol. III, p. 166.

Differs from the type in having its leaves gradually reduced from the middle of the stem upward almost as much as in $E$. salsuginosus ; and more notably different in having twice as many and much more slender involucral bracts, and about 50 rather narrow rass. In damp, grassy thickets, Queen Charlotte Islands, B.C. Herb. No. 11,205. (Di. G. M. Dauson.) Referred provisionally to E. salsuginosus, var. C'nulaschkensis, Less, by Prof. Macoun in Cat. Can. Plants, Vol. I., p. 233, where some of its distinguishing characters were indicated.

Iva Xaxthifolia, Nutt.

Along Grand Trunk Railway near Clifton, Ont. ( $R$. Cameron.) Waste ground, St. Catherines, Ont. (W. $C$. McCalla.) Introduced from the west along railway. 
Senecio Macounir, Greene, Pittonia, Vol. III., p. 169.

Tufted and apparently somewhat stoloniferous perennial, the slender, nearly naked stems about a foot high, simple, subcorymbose at summit, leafy below, floccose-tomentose throughout; leaves chiefly at and near the base of the stem, hoary-tomentose beneath, more deciduously so above, 3 to 6 lines long, including the slender petiole, this much longer than the obovate or oblong-lanceolate or oblanceolate blade, which is 3-nerved and with variously crenate, or dentate or repand-denticulate margin; heads small (as in S. Fendleri), in a rather compact cymose corymb; bracts of the involucre about 12 or 15 , lanceolate, thinnish; rays as many, yellow; achenes light colored, 5 -angled, with 5 intervening striæ; pappus fine and soft.

Goldstream, (Herb. No. 554), and Mount Benson. (Herb. No. 555), Vancouver Island. (John Macoun.) Distributed as S. lugens, var. exaltatus, Gray.

Senecio Colir mbiands, Greene, Pittonia, Vol. III., p. 169.

Taller and stouter than S. lugens, often 3 feet high, the stems solitary, not clustered, and without a root stock, but proceeding from a not at all deep-seated fascicle of fibrous roots; leaves scattered up and down the lower half of the stem (not clustered at base of a nearly naked stem); pubescence scanty, curled-hairy rather than fine and lanate or tomentose; heads three or four times as large as in $S$. lugens, more than twice as numerous, and the corymb compound; bracts of the involucre more thick and fleshy, scarcely black-tipped; mature achenes light-colored, scarcely angled or even striate.

Hillsides, Farewell Creek, Assiniboia. Herb. No. 11,637; grassy slopes, Guichon Creek, B.C. Herb. No. 16,586. Typical. (Dr. G. M. Dawson.) Confounded with $S$. lugens and figured as that species in Hooker's Flora Boreali-Americana, probably from specimens collected.in British Columbia by Douglas, while Richardson's 
description in the same volume was from sub-arctic specimens of his own collecting. S. lugens is well represented in our herbarium, and seems to be an exclusively sub-arctic and Rocky Mountain species. Specimens from Old Man's River, about 30 miles north of the International Boundary, answer to Richardson's description even better than specimens in our herbarium of his own collecting.

Senecio Newcombei, Greene, Pittonia, Vol. III., p. 249.

Slender and weak, simple stemmed and monocephalous perennial, with thin membranaceous foliage; leaves few and remote, long-petioled, reniform-palmate, i.e, of reniform outline, but distinctly and evenly 7 -lobed, the lobes not deep, from broadly triangular to broadly oval, mucronulate, the whole hardly an inch wide, all the lower on elongated petioles dilated and clasping at the base; the uppermost cuneate or spatulate and sessile; the whole plant with a little loose and probably deciduous lanate pubescence: involucre short and broad, almost campanulate: bracts broad, thin, almost biserial ; calyculate bracts, none; rays, 10 or $12, \frac{1}{2}$ to $\frac{3}{4}$ inch long: ovaries glabrous; pappus rather coarse, almost barbellulate.

Seal Pocks, Dawson Harbour, Skidegate Inlet, Queen Charlotte Islands, 1897. Herb. No. 16,929. (Dr. C. F. Nexcombe.) As pointed out by Dr. Greene, this plant resembles superficially a debilitated and monocephalous Chrysanthemum segetum, and in its pappus, as well as broad involucre, it seems to approach Arnica. But if not a Senecio, it represents a new genus.

Phacelia Frayklinil, Gray; Macoun, Cat. Can. Plants, Vol. I, p. 333.

Additional stations for this species are burnt hillsides north of Prince Albert, Saskatchewan, Herb. No. 12,220. (John Macoun.) East of Lake Athabasca, 1893. (J.W. 
Tyrrell.) Miles Canon, Lat. $62^{\circ}$, north of British Columbia, 1887. (Dr. G. M. Dawson. Wm. Ogilvie.)

Phacelia sericea, Gray; Macoun, Cat. Can. Plants; Vol. I., pp. 333 and 567.

P. sericea, Gray, var. Lyallii, Gray; Macoun, Cat. Can. Plants, Vol. I., p. 333 in part and p. 567.

Common in the Rocky Mountains from Lat. $52^{\circ}$ south to the International Boundary, Roger's Pass, Selkirk Mountains, alt. 4,500 ft.; Mount Arrowsmith, Vancouver Island, alt. 5,500 ft. (John Macoun.)

- Phacelia sericea, Gray, var. Lyallii, Gray.

Our only Canadian specimens of this species were collected in 1895 by Prof. Macoun on the high slopes of Sheep Mountain, Waterton Lake, Rocky Mountains.

Amsinckia echinata, Lehm.

Near an old mining camp at Revelstoke, B.C., July 21st, 1890. Introduced from the United States. (John Macoun.) New to Canada.

Amsi $\$ CKIA LYCOPSOIDEs, Lehm.

'A. lycopsoides, Lehm. var. bracteosa, Macoun, Cat. Can. Plants, Vol. I., p. 568.

Mary Island, Gulf of Georgia, B.C., 1885. (Dr. G. M. Darson.) Our only Canadian specimens. The type was collected by Scouler on an island or along the shores of the Straits of Juan de Fuca.

Amsinckia lycopsoldes, Lehm, var. BRacteosa, Gr. ; Macoun, Cat. Can. Plants, Vol. I., p. 338.

Common on Vancouver Island, B.C.

Mrosotis collina, Hoffen.

Low fields, Edmonton, Ont., 1890. (Jas. White.) New to Canada. Introduced. 
Mrosotis rersa, Nutt, var. Macrosperda, Chapm.

New stations for this species are Agassiz, B.C., and Deer Park, Lower Arrow Lake, B.C. (John Maconn.) Eastern limit in Canada. Not a very well defined variety and probably only a western form of $\boldsymbol{M}$. verna, which has not been collected in Canada west of Ontario.

STMPhYTuM ASPERrTMum, Sims.

Waste places at Spence's Bridge, B.C., 1889. (John Macoun.) Escaped from cultivation, and naturalized. Not before recorded from Canada.

Orosmodicy Carolixiaxem, DC., var. Molle, Gray.

New stations for this plant are Souris, Man. (Thos. L. Walker.) Brandon, Man. Herb. No. 12,258 and StandOff, Belly River, Alta. Herb. No. 11,841. (John Macoun.) -

Iтомға QUAMOCLIT, L.

Climbing over weeds near the upper Suspension Bridge at Niagara Falls, Ont. (R. Cameron.) Probably a garden escape, but not before recorded as being naturalized.

Solanum triflorum, Nutt.

Along the C. P. Railway at Port Arthur, Ont. (Dr. and Mrs. N. L. Britton and Miss Timmerman.) Introduced from the west.

A NTIRRHINTUM ORONTIUM, $\mathrm{I}$.

Niagara Falls, Ont. (R. Cameron.) Only record for Eastern Canada.

Livaria vUlgaris, Mill.

Waste places, Beacon Hill, Vancouver Island, B.C. (John Macoun.) Not recorded west of Ontario.

Mimulos alatus, Ait.

Wet places in a ditch which crosses the 2nd concession 
line, township of Harwich, and runs into the foot of Rondeau Harbour, Elgin Co., Ont., Aug. 18th, 1897. (Dr. A. J. Stevenson and J. Dearness.) New to Canada.

Mrmulus alsinoides, Benth.; Macoun, Cat. Can. Plants, Vol. I., p. 358 in part.

Abundant on Vancouver Island. North Arm, Burrard Inlet, B.C. (J. M. Macoun.) Yale, B.C., and Agassiz, B.C. (John Macoun.) This species seems to be confined in Canada to the vicinity of the Pacific coast.

\section{Mimulus floribundus, Dougl.}

Botanie Creek, north of Lytton, B.C. (Jas. McEvoy.) Damp places at Sproat, Columbia River, B.C. (John Macoun.) Elk River, Kootanie River, B.C. (Dr. G. M. Dawson.) Not before recorded from Canada. The specimens referred to this species in Macoun's Catalogue of Canadian Plants, Vol. I., p. 571, prove to be small plants of $M$. moschatus, Dougl.

Mimulus moschatus, Dougl.; Macoun, Cat. Can. Plants, Vol. I., p, 358.

M. floribundus, Macoun, Cat. Can. Plants, Vol. I., p. 571. Beaver Creek, Selkirk Mts., B.C.; Revelstoke, B.C.; Kootanie River, near its junction with the Columbia River, B.C.; Burrard Inlet, B.C.; common on Vancouver Island. (John Macoun.) Quesnell Lake, B.C. ( $A$. Bowman.) Anstey Creek, Shuswap Lake, B.C. (J. $M$. Macoun.) The var. sessilifolius, Gray, is much commoner than the type on Vancouver Island, but has not been found elsewhere in Canada.

Mimulus Nasutus, Greene; Macoun, Cat. Can. Plants, Vol. I., p. 571.

Lower Arrow Lake and Sproat, Columbia River, B.C.; common on Vancouver Island. (John Macoun.) Among the specimens from Sproat are some which are very 
canescent and vary somewhat from the type as to foliage, but they do not appear to be separable from $M$. nasutus.

\section{Mimulos loteus, I.}

There are some thirty or forty sheets of Mimulus, labelled $M$. luteus, in our herbarium. These include many forms and varieties, and we believe several species, but we find it impossible even with Dr. Greene's "Mimulus luterus and some of its allies" in hand to satisfactorily separate and determine our specimens. They cover a wide range-from the Cypress Hills, Alberta, through the Rocky Mountains and British Columbia north to the Aleutian Islands, including Unalaska, the locality from which seeds of $M$. Langsdorffi were taken to Europe, but the various forms so intergrade that our present knowledge does not enable us to definitely and finally separate them.

Orthocarpus patlescens, Gray.

Lower Arrow Lake, Columbia River, B.C. (Dr. G. M. Dauson. John Macoun.) First collected by Dr. Dawson in 1889 and referred to Castilleia pallida. New to Canada.

Pedicularis contorta, Benth.

New stations for this rare plant are Mt. Aylmer, Devil's Lake, Rocky Mountains, alt. 6,000 ft. (John Macoun.) Toad Mountain, Kootanie Lake, B.C., alt. 6,000 ft. (Jas. M. Macoun.)

Pedicularis racemosa, Dougl. ; Macoun, Cat. Can. Plants, Vol. I., pp. 368 and 572.

Common on sub-alpine slopes throughout British Columbia. Near the road to Union Mines, Comox, Vancouver Island; Mount Mark, V.I., alt. 3,000 ft. (John Macoun.) Not before recorded from Vancouver Island. 
Penstemon confertus, Dougl. ; Macoun, Cat. Can. Plants, Vol. I., pp. 354 and 570.

Prairies near Sage Creek, Milk River, Assa. Herb. No. 11,859. (John Macoun.) Eastern limit in Canada.

Penstemon diffusus, Dougl. ; Macoun, Cat. Can. Plants Vol. I., p. 357.

New stations for this species are Botanie, north of Lytton, B.C.; Griffin Lake, B.C. (Jas. M. Macoun.) Agassiz, B.C. ; Cowichan River, Vancouver Island. (John Macoun.)

Pinguicula villosa, L. ; Macoun, Cat. Can. Plants, Vol. I. p. 376 and Vol. II., p. 349.

Bogs, Lat. $60^{\circ} 30^{\prime}$, Long. $104^{\circ}$. (J. W. Tyrrell.) The Lake Mistassini, reference, (Pursh), is, as Prof. Macoun suggests in his catalogue, to $P$. vulgaris, which is very common about that lake.

Verbena hastata, L. ; Macoun, Cat. Can. Plants, Vol. I., p. 379 .

Sicamous, B.C.; near Victoria and at Sumas River, Vancouver Island. (John Macouin.) Not before recorded west of Gold Range, B.C.

LAMIUM AMPLEXICAULE, L.

A weed in gardens at Comox, Vancouver Island. (John Macoun.) Not recorded from west of Ontario.

Lycopus lucidus, Turez., var. Americanus, Gray; Macoun, Cat. Can. Plants, Vol. I., p. 382.

Kamloops, B.C. (John Macoun.) Bonaparte River, B.C. (Jas. McEvoy.) Not recorded west of

Monalida fistulosa, L., var. Rubra, Gray.

In thickets at Wingham, Ont. (J.A.Morton.) - New to Canada. 
Nepeta Glechoma, Benth.

Waste places, Battle Harbour, Labrador. (Rev. $A$. Waghorne.) Not before recorded from Labrador.

Plantago borealis, Lange.

P. maritima, Macoun, Cat. Can. Plants, Vol. I., pp. 393 and 575 in part.

Commonly referred to $P$. maritima, but a good species. Our specimens are from Battle Harbour, Labrador, Herb. No. 16,890. (Rev. A. Waghorne.) Fort Chimo, Labrador, Herb. No. 15,955. (A. P. Louc.) Nachvak, Labrador, Herb. No. 16,891; Nottingham Island, Hudson Strait, Herb. No. 16,892. Fort Churchill, Hudson Bay. Herb. No. 16,889. ( $D r . R$. Bell.) $P$. panciflora, Pursh, is a very different plant, and has nothing to do with this species.

Asarum Cafadense, I.

Mr. E. P. Bicknell, in the Bulletin of the Torrey Botanical Club for November, 1897, has described a new species of Asarum-A. reflexum-hither£o confounded with $A$. Canadense. We have in the herbarium of the Geological Survey typical specimens of both species from the United States, $A$. Canadense from the New England States, $A$. reflexum from Ohio. Our Canadian species are all from Ontario. Those collected at Ottawa in the eastern part of the province very nearly approach $A$. Canadense, as described and figured by Mr. Bicknell; those from the western part of the province are referable to $A$. reflexum rather than to $A$. Canadense, but none of our specimens are typical representatives of either species, the series apparently connecting the two species. Canadian collectors should study this genus in the field with $\mathrm{Mr}$. Bicknell's descriptions in hand.

Since writing the above Mr. J.M. Dickson, of Hamilton, has sent me drawings of two specimens of Asarum, one of which represents $A$. Canadense, the other $A$. reflexum, 
probably the variety ambignum, as Mr. Dickson writes that the calyx is tomentose and the lobes very longpointed.

Trillium grandiflordm, Salisb.

Monstrosities of this species are not uncommon in South Western Ontario, a fine series in our herbarium having been received from Mr. J. Dearness, London, Ont. ; Mr. R. Cameron, Niagara, Ont.; Mr. J. M. Dickson, Hamilton, Ont., and Mr. Wm. Scott, Toronto, Ont. Mr. Dickson, after studying in the field the different forms found in the vicinity of Hamilton, sent me the following notes :-

"A few years ago several green flowered Trilliums were observed growing in a flat piece of woods on the banks of the Waterdown Creek, near this city. To see if they were persistent and not merely sports of a season, I visited the locality during the latter part of May, 1897, and, upon a close inspection, found several remarkable forms not previously noted. Some of these may be described as below :-

"1st. Several with white edgings and markings on sepals. The most remarkable of these had one sepal green, one half green and half white and the third pure white, while both sepals and petals were inserted in a distinct spiral on the axis; the leaves were normal.

“2nd. Leaves and sepals normal. Petals marked with green lines or bands toward the base.

"3rd. Leaves and sepals normal. Petals green, with a narrow white margin.

" 4th. Leaves distinctly petiolate. Petioles one to. three inches long; sepals white, with a green stripe down the midrib. Petals narrowed, lanceolate, white, with broad green band in centre, running from base, and terminating near the apex.

" 5 th. Leaves as in No. 4. Sepals normal. Petals 
obovate. Apiculate long clawed, with broad green centres and white margins.

" 6 th. Leaves ovate, long acuminate, petioled. Petioles ascending, widely spreading, seven inches long, inserted about two inches above the root stock and six or seven inches below the Hower. Sepals normal. Petals green, with white margins.

"All the flowers seemed to be perfect, some having a sterile filament, which might be due to accident."

To. 6 was potted and photographed by Mr. Dickson. When photographed the stem was 10 inches high, the peduncle being 8 inches in length. The petioles were $8 \frac{1}{2}$ inches long; leaves $2 \frac{1}{2}$ inches long, $1 \frac{1}{2}$ inches broad, longacuminate.

A remarkable form. sent from Niagara by Mr. Cameron, has the petals changed into petioled leaves (petioles more than an inch long.) Mr. Cameron has also sent me a photograph of a very large flowered plant with 21 pure white petals. It was found on Navy Island, Niagara River, by Mr. Cameron in 1S96. He transplanted it, and last summer two Howers were produced, each with 21 petals. Mr.Cameron also reports a double yellow-flowered dwarf specimen from Niagara Falls, but this is probably some ather species. 



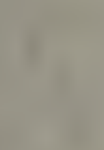

(
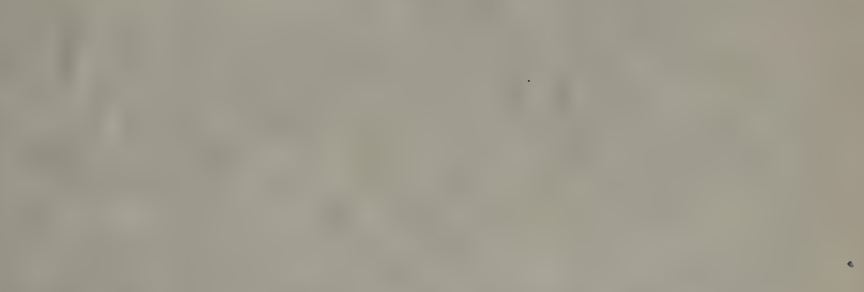



\title{
Contributions from the Herbarium of the Geological Survey of Canada.
}

(By Permission of the Director).

BY

\author{
JAMES M. MACOUN, \\ Assist. Naturalist, Geol. Survey, of Canada.
}

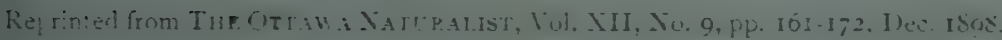



Reprinted from The Ortiwa Nittralist for December, 1Sg8, Vul. NII, No. 9, Pp. 161-172.

\title{
CONTRIBUTIONS TO CANADIAN BOT ANI.*
}

\author{
By James M. Macoun.
}

Assist. Naturalist Geol. Survey of Canada.

\section{XII.}

Ranuncluds inaminus. (ireene, Pittonia III, p. 9 r.

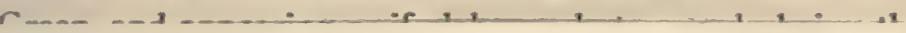

\section{ERRATA.}

P. I61, line I I, for "Jumping Pond" read "Jumping Pound."

P. 162, line 18, for "glabrous and glabrous" read "glabrous and glaucous."

P. 164, for "Polygala verticellata" read "Polygala vertiCillata."

P. r65, line 4 , for "spicis" read "species."

P. I65, line 16 , for "nardijolia" read "nardifnlia."

P. I66, for "Anthyllus" read "Anthyllis."

I". 167 , line 7 , for "intermedius" read "intermedia. Wat. ;"

P. I69, line 2, for "Vaucouver" read "Vaneouver."

Pp. I69 and i70, for "uva-ursi " read "Uva-ursi."

Spreadborough.) Northern limit.

NAsturtium Sylvestre, R. Br.

Naturalized along the road in front of Ball's Mills, Lincoln Co., Ont. ( $W . C$. McCalla.) New to Canada.

Cardamine angulata, Hook.

Spring House Cove, Dawson Harbour, Queen Charlotte Islands, B.C., June 26th, I897. (Dr. C. F. Nerucombe.) New to

"Parts I.XI of these contributions appeared in the "Canadian Record of Science" during the years $1894-98$. 

Reprinted from Tue OtT.wa NittRal.1st for December, ISgs, Vul. XII, No. 9 , Pp. $16 I-172$.

\section{CONTRIBUTIONS TO CANADIAN BOTANI.*}

By James M. Macoun.

Assist. Naturalist Geol. Survey of Canarla.

XII.

Ranunculus inamonus. (ireene, Pittonia il, p. 9 I.

Green, and appearing as if glabrous, but sparsely hairy, the the stoutish stems 6 to 12 inches high; radical short-petiolate leaves obovate-flabelliform, at summit either crenate-toothed or 3 -lobed, the cauline usually quite sessile and once or twice ternately divided into oblanceolate segments; peduncles short and slender, often 3 to 5 together and subumbellate ; corolla 3 to 5 lines broad, the 5 petals obovate-oblong; head of small pubescent achenes ovoid or short-cylindraceous, the linear receptacle white-hispid.

Banff, Rocky Mountains, I89I ; from several localities in the foot-hills, i.e., Jumping Pond Creek, Herb. No. I8,039; Bragg's Creek, Elbow River, Herb. Nos. I8,037 and I 8,038, and Moose River, Elbow River, Herb. No. I8,040. (John Macoun.)

An excellent species well separated from all forms of $R$. affinis to which it has at various times been referred.

Aquilegia flavescens, Wats.

Not rare on mountain-sides on both sides of the summit at Yellow Head Pass, Rocky Mountains, Lat. $52^{\circ}$ 50', 1898. ( $W$. Spreadborough.) Northern limit.

Nasturtuma SYlvestre, R. Br.

Naturalized along the road in front of Ball's Mills, Lincoln Co., Ont. ( $W . C$. McCalla.) New to Canada.

Cardamine angulata, Hook.

Spring House Cove, Dawson Harbour, Queen Charlotte Islands, B.C., June 26th, I897. (Dr. C. F. Newcombe.) New to

"Parts I-XI of these contributions appeared in the "Canadian Record of Science" during the years $1894^{-98}$. 
Canada. Collected on the banks of the Columbia by Douglas and Scouler, and in many parts of Oregon and Washington in recent years, but never on Vancouver Island or the B. C. coast, where it doubtless occurs.

Dentaria Californica, Nutt.

Cardamine angulata, Macoun, Cat. Can. Plants, vol, I, p. 41. Dentaria tenella, Macoun, Cat. Can. Plants, vol. I, p. 39.

Common on Vancouver Island.

Dentaria geminata, Wats.

Rich woods, Burnaby Lake, near New Westminster, B.C., 1889. ( J. M. Macoun.) New to Canada. Agrees in every respect with specimens collected in the upper valley of the Nesqually River, Washington, by Mr. O. J. Allen.

Arabis nrepanoloba, Greene, Pittonia, vol. ili, p. 306.

Prennial, the several stout decumbent stems 8 to 12 inches high ; herbage seemingly glabrous and glabrous, but the small oblanceolate lowest leaves sparsely stellate hairy; the oblong sessilc auriculate cauline ones like all the remaining parts of the plant glabrous ; corollas red, $1 / 4$ inch long or more; fruiting raceme $2-5$ inches long, the broad spreading and slightly falcaterecurved pods 2 inches long including the short pedicel, about I I $/ 2$ lines wide, abruptly acutish, the stigma sessile; valves with with a manifest nerve at base only; seeds in two rows under each valve, flat, obovoid, narrowly winged.

Collected in August, I 89I, by Prof. John Macoun at Devil's Lake, Banff, Alberta, and distributed as A. Lemmoni, to which it is indeed related, yet easily distinguishable by its larger dimensions, much less pubescent lower leaves, and especially by its pods, which are twice as broad and with two rows of seeds.

Arabis Nuttalli, Robinson.

High dry slopes of mountains at Crow's Nest Pass, Rocky Mountains, alt. 7000 ft., Aug. 2nd, 1897. Herb. No. 18,162. (John Macoun.) New to Canada. The habitat of this plant is stated by Dr. Rubinson to be "chiefly on low grounds in [mountairi] valleys." The habitat as given by Nuttall "lofty dry hills," 
seems the better one. Nuttall's description of the root "thick crowned with vestiges of former leaves and stems," well describes Prof. Macoun's specimens.

Alliaria officinalis, Andrz.

Sisymbrium Alliaria, Scop. Can. Rec. of Science, Nov., 1894. Alliaria Alliaria, (L.) Britt.

At the Cove, Quebec, Que. (Mrs, Brodie.) Not before recorded from province of Quebec.

Sisymbrium altissimum, I.

S. Sinapistrum, Crantz.

Ballast heaps, North Sydney, Cape Breton Island, N.S., 1898. (Jolın Macoun.) Not before recorded from Nova Scotia. Okanagan Landing, B.C. (J.R. Anderson.) Western limit.

Conringia perfoliata, L.

Erysimum Orientale, R. Br. Can. Rec. of Science, Nov., I 894 .

Now represented in our herbarium from many localities in the North-west and from Snelgrove, Ont. (Jas. White.) and Stamford, Ont. (R. Cameron.)

Parrya macrocarpa, R. Br.

Summit of Father Mt. alt. 6,000 ft. Yukon District, July 3rd, 1898. (J. B. Tyrrell.) Not before collected in that region.

DRABA HIRTA, L.

Crevices of rocks, Big Intervale, Margaree, Cape Breton Island, N.S, 1898. (Joln Macoun.) Not before recorded from Nova Scotia. Northern Labrador. (A. P. Low.)

Draba prefalta, (ireene, Pittonia, vol. ili, p. 306.

Annual, very erect and strict, mostly quite simple, Io to 15 inches high, subcinereous throughout, even to the pods, with short stellate hairs ; rosulate basal leaves oblong-lanceolate, $1 / 2$ to $3 / 4$ inch long, entire, or with two or three pairs of sharp teeth, the two or three cauline similar; flowers whitc ; the loose fruiting raceme often 5 or 6 inches long, the almost lanceolate pods $1 / 2$ inch long or more, erect on ascending pedicels nearly as long, 
acute, rather turgid, not contorted, a channel-like depression marking the line of the mid-vein from its base to near the middle.

This is a plant which by its annual root and large size would be taken for a relation of $D$. nemorosa, but for its very strict habit, narrow leaves and white flowers. Common everywhere in the Rocky Mountains between 4,500 ft. and 6,000 altitude. Our our herbarium specimens are from Banff, Rocky Mountains, I89I (type locality) ; Kicking Horse Pass, Rocky Mountains, I 885 ; Crow's Nest Pass, Rocky Mountains, I897. Herb. No. 18,136. (John Macoun.) Yellowhead Pass, Rocky Mts., I 898. (W. Spreadborough).

LESQUERELLA ARCTICA (DC.) S. IVats.

Vesicaria arctica, Rich.; Macoun, Cat. Can. Plants, vol. I, pp. 54, 490 .

Athabasca River near Lac Brulè, northern Alberta, July, 1898. (W. Spreadborough.) Specimens collected by Mr. Spreadborough do not differ in any respect from those collected by Drummond in the same latitude and distributed from the British Museum as Physaria didymocarpa.

Eutrema Edwardsil, R. Br.

Northern Labrador, 1897. (A. P. Low.) Not before recorded from Labrador.

Diplotaxis tenuifolia, DC.

Bank of the new Welland Canal north of St. Catherines, Ont. (W. C. McCalla.) Not recorded west of Nova Scotia.

Myagrum PERfoliatum, L.

On Gallow's Hill, Quebec, Que. (Mrs. Brodie.) Introduced from Europe. Not before recorded from Canada.

Polygala verticellata, L.

On the open prairie on the ridge near the Insane Asylum, Brandon, Man., I896. Herb. No. I2,336. (Jo/nn Macoun.) Recorded from but one other locality in Manitoba.

Strllaria GR minea, L.

Near Niagara, Ont. (R. Cameron.) Western limit in Canada. 
Arenaria arctica, Stev.

A single specimen of this species was collected in Northern Labrador by Mr. A. P. Low in 1897 . According to Dr. Robinson this specis is confined to Alaska and adjacent coasts and our other herbarium specimens are all from that region, but there can be no doubt about the identity of Mr. Low's plant.

Arenaria CAPILlaris, Poir., var. Formosa, Regel.

A. capillaris, var. nurdifolic, Macoun, Cat. Can. Plants, Vol. I. p. 70, in part, and vol. I, p. 496.

Common in the Rocky Mountains and British Columbia. All our specimens with the exception of those from Sproat, B.C., are this variety. The specimens collected at Sproat are much larger, with larger flowers (petals more than twice the length of the calyx), and much longer spreading pedicels. The whole plant is glabrous, but is not certainly referable to either $A$. capillaris or the var. nardijolia.

Hypericum nudicaule, Walt.

H. Sarothra, Michx. Macoun, Cat. Can. Plants, vol. I, p. 85.

In sandy fields at Sandwich, Ont. Herb. No. I8,317 (John Macoun.) This is the only Canadian locality from which we have specimens of this plant.

Helianthemum Canadense, Michx.

Our only specimens of this species are from Rice Lake Plains, Ont. : Sandwich, Ont. (John .Macoun.); and Niagara Falls, Ont. (R. Cameron.)

Helianthemum majus, B. S. P.

H. Canadense, Macoun, Cat. Can. Plants, vol. I, p. 60, in part, and vol. I, p. 492.

Apparently more widely distributed than the last in Canada. Our specimens are from Kingston, N.S. ( John .Macoun.) ; London, Ont. (Dr. Burgess). High Park, Toronto, Ont. (/as. White.) Lake of the Wonds, Ont. (Dr. G. M. Dazuson).

LecheA INTERMEdia, I.eggett.

All the references under L. minor. Wacoun, Cat. Can. Plants, 
vol. I, p. 6I, are L. intermedia as far as they are covered by our herbarium specimens. We have no Canadian specimens of L. minor.

Lechea JUNiperina, Bicknell.

First collected by Dr. C. A. Hamilton in I 89 I on dry sterile roadsides, south of Mahone Bay, N.S., and in adjacent pastures, more particularly along the Fauxbourg road. New to Canada. Anoda Lavateroides, Medick.

In cultivated grounds at St. Catherines, Ont. ( $W . C$. MeCalla.)

Geranium pratense, L.

In fields at Quebec, Que. (Mrs. Brodie.) Only other Canadian record is from New Brunswick.

Ceanothus velutinus, Dougl., Macoun, Cat. Can. Plants, vol. I, pp. 96 and $5 \circ 3$.

C. velutinus var. lovigatus, T. and G; Macoun, Cat. Can. Plants, vol. I, pp. 96, in part, and 504.

Common in the Rocky Mountains and throughout British Columbia. All the references under var. lovvigatus in Macoun's catalogue with the exception of Menzies' from Nootka go here.

Ceanothus velutinus, Dougl, var. levigatus, T. and G.

Our only specimens of this plant were collected by Prof. Macoun in 1887 at Horne Lake, Vancouver Island, not far from Nootka, where it was first collected by Menzies.

Rhamnus Frangula, L.

In a thicket in North London, Ont., 12 to 15 feet high and 3 to 5 inches thick at base. Collected by Mr. J. Dearness, July Ist, I 898. Well naturalized. Not before recorded.

Trifotrum involucratum, Willd.

West coast of Queen Charlotte Islands, 1897. (Ir. C. F. Newcombe.) Northern limit.

ANThyllus vUlmeraria, L.

First noticed in clover fields about New Durham, Oxford 
Co., Ont., in the summer of 1897 , and again in 1898 . Communicated by Dr. T. J. W. Burgess.

Lespedeza Virginica (Lo) Britt.

In thickets at Leamington, Ont., I 892. (John Macoun.) New to Canada.

Lespedeza fRutescens, Britt.

L. Stuvei, var. intermedius, Gray. Man. Ed. vI. p. 147.

L. reticulata, Macoun, Cat. Can. Plants, vol. I, pp. II9 and 5 II.

Not rare in sandy wonds and thickets from Niagara to Sarnia.

Lathyrus myrtifolius, Muhl.

L. paluster var, myrt,folius, Gr. ; Macoun, Cat. Can. Plants, vol. I, p. 122.

In thickets at Brandon. Man. Herb. No. 12,528. 1896. (John Mucoun.) Western limit.

PRUNus AVIUM, L,

Along a creek bank west of Niagara-on-the-Lake, Ont. (J. Pearness.) Not before recorded in Canada.

SPIREA Lobata, Jacq.

Escaped from cultivation and naturalized at Boylston, N.S. (Dr. C. A. Hamilton.) Not before recorded in Canada.

SPIRAEA SORBIFolia, L.

Along roadsides near Baddeck, Cape Breton Island, N.S., 1898. (John Mucoun.) Escaped from cultivation, but not before recorded as well naturalized.

Potentulla nemoralis, Nestler : Maciun, Cat. Can. Flants, vol. I, p. I42.

Discovered many years ago at Ste. Ann's, Cape Breton Island, N.S., by Dr. Lawson. Collected in 1898 by Prof. Macoun between Ste. Ann's and Baddeck Bay, Cape Breton Island.

Ribes floridum, L'Her. ; Macoun, Cat. Can. Plants, vol. I, p. I63.

Collections of recent years have shown this species to be more widely distributed west of Manitoba than was supposed. 
We have it from Old Wives Creek, Assa., and Medicine Hat, Assa. (John Macoun.) Maple Creek, Assa. (J.M. Macoun.) and Ste. Anne, west of Edmonton, Alta. (W. Spreadborough.) SEDUM DIVERgens, Wat.

Mountains at Yellow Head Lake, Rocky Mountains, Alt. 6,000 ft. July I7th. I898. (W. N reailburough.) Not before recorded from Canada though some Vancouver Island references to $S$. Oreganum may be this species.

Epilobium luteum, Pursh.

By springs on the mountain side, west of Henry House, Athabasca River, Lat 53․, Alberta. Alt. 5,500. Aug. 30th, I 898. (W. Sprendborongh.) Not before collected on east side of Rocky Mountains, and not so far north anywhere in Canada.

Angelica SYlvestris, L.

Meadows and old fields at Louisburg, Cape Breton Island, N.S. 1898. (Joh? Mucoun) Probably introduced by the French in the 17 th Century, Not before recorded.

Scabiosa succisa, L.

In an old field at the head of the bay at Louisburg, Cape Breton Island, N.S. I 898. (John Micoun.) Probably introduced by the French in the 17 th Century.

Grindelia macrophylla, Greene, Pittonia, vol. 1II, p. 297.

Stout erect herbaceous, 3 fect high, corymbosely branched at summit, wholly glabrous, or with a few scattered short hairs on the pedunculiform branches; leaves thinnish, the radical a foot long or more, lanceolate, scarcely petiolate, incisely serrate ; the cauline oblong or spatulate oblong, 2-4 inches long, sessile and clasping by a broad basc, cuarscly scrrate, or the uppermost reduced and entire; involucres large, hemispherical, scarcely glutinous, their narrow bracts with a long slender spreading acumination ; rays many, an inch long or more.

Described from specimens collected by Dr. Edw. L. Greene from the margin of a tide-water swamp near Vancouver, B.C., in July, I890. Represented in the herbarium of the Geological 
Survey by specimens collected by Prof. Macoun at Barclay Sound, Vaucouver Island, I887, and Burrard Inlet, near Vancouver, B.C., 1889.

Bidens chrysanthemoides, Michx.

Beautiful specimens of this species were collected in Lincoln Co., Ont., Sept. I6th, I897, by Mr. W. C. McCalla.

Centaurea solstitialis, L.

Collected on a farm about 8 miles S.E. of London, Ont. Communicated by Mr. J. Dearness.

Crepis Tectorum, L.

On lawns, introduced at Wingham, Ont., I897. (J.A. Morton.) Common in Woodland Cemetery, London, 1897 (J. Dearness.) Not before recorded in Canada.

Hizracium priealtum, Vill.

Don Valley, near Toronto, Ont., 1894 . Covering about half an acre of the C. P. Ry. embankment. (W. Scott.) New to Canada.

Lobelia spicata, Lam.

Well established at Holland Cove,entrance to Charlottetown. Harbour, Prince Edward Island. (L. W. Watson.)

Arctostaphylos media, Greene, Pittonia, vol. ir, p. I 71.

Near the Nanaimo River, Vancouver Island (J.R.Anderson.) Not before collected in Canada, and known only from Washington and the above locality. Mr. Piper who collected the specimens from which the species was described wrote of the plant as seen by him: "It is found sparingly on dry gravelly ground in Mason County, where both $A$ tomentosit and $A$. uva-ursi are very abundant, and always in a position to indicate a hybrid origin. It is found most commonly in beds of $A$. uvc-ursi with plenty of $A$. tomentosa near by, and is easily distinguished from A. uva-ursi by its larger size, merely procumbent (not prostrate) habit, and paler foliage." (Pittonia, vol. II. p. I /I.) Mr. Anderson sends me the following note on the specimens collected by him : "Regarding the Arctostaphylos, Mr. Piper's description of 
occurrence coincides exactly in every respect with mine, and from the fact of finding it surrounded by quantities of $A$ tomentos $a$ and $A$. uva-ursi, I was also lead to believe it might be a hybrid." This note was written in 1897 ; in $1898 \mathrm{Mr}$. Anderson collected and sent to the herbarium of the Geological Survey a fine series of specimens, which clearly show that $A$. media is a hybrid.

Asclepias tuberosa, L。

Tarr Island, River St. Lawrence and below Rockport, Leeds Co., Ont. (Rev. C. J. Young.) Eastern limit in Canada.

Gentiana frigida, Hænke.

Above the tree line, alt. 5,000 ft., Nishing River, Lat, $62^{\circ}$, Yukon District. Aug. 22nd, I898. (J. B. Tyrrell.) Not before recorded from Canada. This plant differs in several important respects from Behring Sea specimens, agreeing more nearly with specimens from Colorado.

Phlox Richardsonil, Hook.

Mountains by Selkirk Trail, west of Aishihik Lake, Yukon District, Sept. 7 th, 1898. (J.B. Tyrrell.) Only known before from Arctic sea-coast.

Phacelia Purshir, Buckley.

Growing among clover at the Central Experimental Farm, Ottawa, Ont. ( $W m . T$. M ^ ^oun.) Introduced from the United States. Not before recorded in Canada.

Plagiobothrys echinatus, Greene, Pittonia, wol. ili, p. 262.

Habit of $P$. tenellus and of the same size, rather more branching, the branches strict, densely spicate at summit; the usual pubescence augmented by sparse spreading and rather hispid hairs ; nutlets rather more than $3 / 4$ line long, whitish, distinctly carinate on the back at least toward the apex, the transverse rugosities few, slender and indistinct,incrcly indicating the lines of numerous well elevated and sharp murications, the whole back thus appearing somewhat regularly echinate.

Cedar Hill, Vancouver Island, I6th May, I887. (Jolm

\section{Macoun.)}


Linaria minor, Desf.

Along the G. T. Ry., near the Cove Bridge, west of London, Ont., Juns, 1898. (J.A. Balkwill.) Only one other Canadian record-St. John, N.B.

Collinsia verna, Nutt. ; Can. Rec. Sc., Jan, I 895.

In woods between Putnam and Ingersoll, Ont., 1896. $(J$. Dearness.) Second Canadian record.

Mimulus moschatus, Dougl.

By a brook on the farm of Mr. Peter Cavanagh, Middle Settlement of Barney's River, Pictou Co., N.S. (Miss Maria Cavanagh.) Not before recorded from Nova Scotia. Though probably introduced or adventitious, the conditions under which it is growing make it appear possible that this species is indigenous in Nova Scotia. It is at any rate well naturalized. Miss Cavanagh writes : "I have seen it growing there for four or five years. Previous to that time $I$ had no opportunity of examining the brook. It grows luxuriantly and in great abundance in an elevated region along the ridge of the watershed between the rivers flowing north and south. The place is too cold for plum trees."

Stachys Germanica, L.

Well established near Guelph, Ont. Collected in two widely separated localities near that town. I897. (J.C. McCalla.) New to Canada.

Amarantus chlorostachys, Willd.

North of Leamington, Essex Co., Ont., r 892. (J. Dearness.) Not before recorded in Canada.

Chenopodium Vulvaria, L.

Plentiful around waste heaps and along roadsides at Galt, Ont. (William, Herriatt.) Probably introduced in foreign merchandise. New to Canada.

Acalypha Virginica, L.

Among small stones and grass along roadsides at Clearland, N.S. (Dr. C. A. Hamilton.) Not recorded east of Quebec. 
Larix LyalliI, Parlat.

Mr. Walter D. Wilcox found this tree in 1898 on Mt. Hector, about 1 I miles from Laggan, Rocky Mts. This station extends the limit of $P$. Lyallii some 3 or 4 miles further north than it was known to occur. Mr. Wilcox was also on the mountains at Glacier Lake, head of Saskatchewan River, and at the source of the Athabasca, but did not see this larch, so that its northern limit may now be considered to be definitely fixed.

Calamovilfa longifolia, (Hook.) Hack.

Ammophil, longifolia, Benth. and Hook.; Macoun, Cat. Can. Plants, vol. IV, p. 208.

Not rare on sandy ground in the northern part of Lambton Co. and southern part of Huron Co., Ont. (J. Dearness.) Eastern limit in Canada.

Elymus elymoides, (Raf.) Sweezy.

One specimen collected by Prof. Macoun in 1897 on the side of a mountain at Crow Nest Pass, Rocky Mts. New .to Canada. 




\section{CONTRIBUTIONS TO CANADIAN BOTANY.}

JAMES M. Macor:

Assist. Naturatist, Geol. Survey of Canada.

XIII

Reprinted from The OttaWA NatiR.alist for October, 1899 , Vor. XIII. 



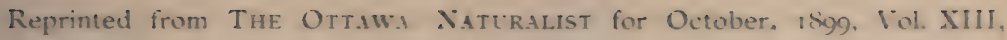
No. 7, pp. 158-169.

\section{CONTRIBUTIONS TO CANADIAN BOTANY.}

By James M. Macolx, Assist. Nateralist, Geol. Survey of Canada.

XIII.

ANemone riparla, Fernald, Rhodora, vol. I, p. 51.

This species recently described by Mr. Fernald is represented in our herbarium by a single specimen collected in 1882 at Madeline River, Gaspé, Que., and in 1899 at Woodstock, I.B, by Prof. John Macoun. Mr. Fernald gives as additional Canadian stations Restigouche Co., X.B. (Fowiler), and Roberval, Lake St. John, Que.

Raxliclles ABurtives, L. var. elcycles, Fernald, Rhodora, vol. $\mathbf{x}, \mathrm{p} . \mathbf{5}^{2}$.

Stems more slender than in the type; the branches slender and flexuous; leaves very thin and lucid; the basal generally of two sorts, some orbicular with a narrow or closed sinus, others reniform as in typical $R$. abortizus ; flowers, achenes and receptacles as in the species but smaller.

Mr. Fernald records this plant from Lake St. John and Tadousac, Que., but it is not represented amony our herbarium specimens of $R$. aborticus. It should be looked for by Canadian collectors.

ISOPYRUM BITERNATUM, T.\& G.

Though collected before in S. W. Ontario any records of this species are of interest to botanists. Mr. Leroy J. Boughner writes of specimens sent to the Geological Survey department: "This little plant was first collected by me during an expedition of the Simcoe High School Scientific Society on May 21st, 1897. It grew sparsely in a cool spot near Lynn lalley, a few miles east of Simcoe. It is supposed to have been introduced from Ohio by railways."

\section{Hesperis matronalis, L.}

A garden escape near Victoria, Vancouver Island. (A. J. Pineo.) Not recorded west of Ontario *

-The Geological limits given in these contributions refer to Canada only. 
Lesquerella occidentalis, Wat.

Dry slopes Osoyoos Valley, B.C., 1898. (C. de B. Green.) New to Canada.

Viola subcordata, Greene, Pittonia, vol. I I1, page 316.

Open or partly open land, Esquimault, Vancouver Island, 6th June, 1896. Herb. No. 18,708. (J.R. Anderson.) A beautiful species nearly related to $V$. Horvellii. Known only from the above locality.

Viola subvestita, Greene.

On the cliff below Governor's Bay, Ottawa, Ont., 1899. ( /. M. Macoun.)

Viola sagittata, Ait.

We have notrue $V$. sagittata in Canada, at least none of the specimens in our herbarium are referable to that species. All specimens so named are either $V$. ovata, Nutt, or $V$. dentatu, Pursh. which may, however, yet prove to be one species.

V. ovata, Nutt.

V. sagittata, Macoun, Cat. Can. Plants, vol. I, p. 6.3 in part.

Our herbarium specimens are from dry fields east of Belleville, Ont. (John Macoun.) Near Hamilton, Ont. (J. M. Dickson.) Strathroy and woods about London, Ont. (J. Dearness.)

V. Dentata, Pursh.

V. sagittata, Macoun, Cat. Can. Plants, vol. 1, p. 63 , in part and vol. I, p. 492 .

Prince Edward Island. (L. W.Watson.) Point Pleasant, N. S. (John Macoun.) London, Ont. (Dr. Millman.) Komoka, Ont. and London, Ont ( $/$. Dearness.) Port Flamboro, Ont. ( J. M. Dickson.) Though kept separate here it is more than probable that $V$. ovate and $V$. dentata are forms of the same species.

Viola septentrionalis, Greene, Pittonia, vol. i i, p. 334, and Ott. Nat., vol. $x_{1} 1$, p. $x_{3}$.

Billings' Bush, S. E. of Billings' Bridge, Ottawa, Ont., 1898. Type locality. Herb. No. I8,561. (J. M. Macoun.) St. Catherines, Ont. (W. C. McCalla.) 
Viola Macotnir, Greene, Pittonia, vol. I I , p. 335 and Ott. Nat. vol. XII, p. 184 .

On dry limestone shingle, growing among grass in the shade of cedars, between Rockliffe Road and Governor's Bay, Ottawa, Ont. Type locality. Herb. No. i8,746. (J. M. Macoun.) The specimens collected by Prof. Macoun, near Hull, and referred to this species in Ottawa Naturalist, represent a new species not yet described.

Viola venustula, Greene, Pittonia, vol. 1 i 1, p. 335, and Ott. Nat. vol. $\times 1$, p. 184 .

In the wet meadows between the Rockliffe Road and Governor's Bay, Ottawa, Ont. Type locality. Herb. No. $18,565 .(J$. M. Macoun.)

Viola cucullata, Ait.

A common violet throughout Eastern Canada. The only species of this group of general distribution.

Viola Dicksonir, Greene, Pittonia, vol iv, p. 65.

$V$. cuspidata, Ottawa Naturalist, vol. xir, p. 185.

Allied to $V$. cuspidutu, but the herbage light-green, the pubescence more sparse and hispidulous, the petaliferous flowers on nearly terete peduncles about equalling the leaves and bibracteolate near the base: sepals lanceolate, either naked or ciliolate: corolla about $3 / 4$ inch long, of a fine lavender-blue, the paired petals, especially the two uppermost, obovate-rhomboidal, the laterals white at base and strongly bearded with indistinctly clavellate hairs, the keel-petal shorter and narrower than the others, more or less conduplicate or convolute especially at the apex, white at base and purple-veined above the white; summer foliage less broad in proportion to its length than in $V$. cuspidati and more apt to be cucullate: apetalous flowers on short but nearly or altogether hypogeous peduncles.

A very common violet in the vicinity of Ottawa and probably abundant throughout Ontario, Mr. J. M. Dickson having collected it at Hamilton and Mr.Wm.Scott at Niagara-on-the-Lake, zueenston, Cartwright and Toronto. Dr. Greene in Pittonia, vol. Iv, p. 
66 , has explained fully the unfortunate circumstances which resulted in the publication of this plant as $V$. cusprdata in my "Notes on Some Ottawa Violets," in the Ottawa Naturalist for January, 1899. I at that time hesitated to publish even six new violets from the cucullata aggregate, and though aware that Dr.Greene's description of $V$. cuspidata did not answer well for our plant it seemed preferable to include it in that species rather than describe another species. Ample material collected this year shows that we have in the vicinity of Ottawa at least four additional species of violets in this group, two of which have recently been described by $\mathrm{Dr}$. Greene and are included in this paper.

Viola populifolia. Greene, Pittonia, vol. i i i, p. 337, and Ott. Nat., vol. Xi I, p. 186.

\section{Port Flamboro, Ont. (J.M. Dickson.)}

Viola elegantula, Greene, Pittonia, vol. iv, p. 66.

Acaulescent and low, the whole plant at the time of petaliferous flowering barely three inches high and the peduncles far exceeding the leaves ; rounded and cordate-reniform leaves pale green and slightly succulent, about $3 / 4$ inch wide, shortpetioled and the petioles erect, the margin lightly crenate and all parts wholly glidbrous : peduncles obscurely angled, bibracteolate abc ve the miadle, the bractlets subulate: sepals lance-linear, obtusish : corolla rather more than halt an inch in length, not as broad as long; petals all similar in size and outline, oblong-obovate, obtuse or retuse, light-blue, the lower three with conspicuous violet veins on a white ground at base, the laterals bearing a low and thin tuft of short strongly clavate hairs, or some of them shortened to mere papillæ; two upper petals naked, in full expansion deflected and concealing the calyx : style elongated: late apetalous flowers small, aerial on short horizontal or recurved peduncles.

In depressions in sandy fields at Eastman's Springs, Ont., and east of Beaver Meadow Lake, near Hull, Que., 1899. (J.M. Macoun.) 
Viola vagula, Greene, Pittonia, vol. iv, p. 67.

Larger than the last, with dark green glabrous rather notably fleshy herbage : leaves at time of petaliferous flowering, about an inch in diameter, somewhat deltoid-cordate, the length equalling or surpassing the breadth, the margin lightly crenate: peduncles surpassing the leaves, obscurely angled or semiterete, bibracteolate in about the middle, the rather obtuse bractlets with a few obscure glandular teeth : sepals oblong, obtuse: corolla nearly an inch in diameter, the breadth commonly greater than the length; petals deep violet, at base darkly venulose on a white ground, all obovate-spatulate, obtuse or notched, the odd one especially broad and often obcordate, the pair next to it bearing each a dense tuft of rather long and slender not in the least clavellate hairs: style not prolonged beyond the anthers : apetalous summer flowers aerial, but their peduncles short and more or less horizontal; their capsules short and thick, not dotted.

Throughout the whole extent of the Beaver Meadow, W. of Hull, Que., I899. ( J. M. Macoun.) A very beautiful species intermediate between $V$. cucullata and $V$. venustula.

Subularia aquatica, L.

In fresh water ponds, Attu Island, Aleutian Islands, Behring Sea, Aug. 29th, 1891. (J. M. Macoun.) Not hefore collected in that region.

Stellaria aquatrca; Scopoli.

Common at Chelsea, Que.

Spheralcea munroana, Spach.

Dry clay " benches," Osoyoos Valley, B.C., I898. (C. de B. Green.) New to Canada.

ACER RUBRUM. L.

Little Turtle River, Rainy Lake, Ont., long. $93^{\circ} \mathrm{W} .(\mathrm{W}$. McInnis.) The western limit for this species.

TRIFOLIUM INCARNATUM, L.

Cultivated for fodder and now becoming extensively naturalized in Ontario. 
Aracallus campestris (DC.) var. Johannensis, Fernald, Rhodora, vol. $I$, p. 88 .

The Canadian stations given for this plant by Mr. Fernald are Isle d'Orleans below Quebec. (Mrs. Shepard, Prof. Brunet.) Mouth of Madawaska River, N.B. (G. U. Hay, G. F. Mattherw.) Crevices of ledges, Aroostook Falls, N.B. (M. L. Fernald.) Rocky banks, Hero's Rapids, Restigouche River, N.B. (G. U. Hay.) Our only herbarium specimens were collected at Aroostook Falls, N.B., by Mr. G. U. Hay, in $188_{3}$ and at Woodstock N. B. by Prof. Macoun in 1890 .

Aragallus caudatus, Greene, Pittonia, vol, iv, p. 69.

Moose Jaw, Assa., June 26th, 1896, Herb. No. 13,957.* (John Macoun.) A very beautiful and distinct species, not at all resembling the common $A$. Richardsonii of the prairies.

Aragallus foliolosus, Hook. Fl. Bor. Am., vol. i., p. 146. O. foliosa, T. \& G. F1., p. 339.

In describing $O$. foliolosa, Hooker says: "Capitula late ovata seu subglobosa, ratione plantce parva, floribus compactis, patentibus, inferioribus reflexis." How an acaulescent plant with compact heads-heads "far more compact" than $O$. carulea-should ever have been referred to $O$. deflexa will probably never be fully explained; that it has no very close affinity with that species is evident. The error doubtless originated in contusing $O$. foliolosi with an apparently acaulescent form of $O$. deflexa, (Proc. Am. Ac. Arts \& Sc., vol. xx, p. 4) the "forma subacaulis" to which Gray referred $O$. foliolosa. It is indeed probable that in describing $O$. foliolosa, Hooker had before him the flowers of that species and fruiting specimens of the sub-acaulescent form of $O$. deflexa which is not uncommon in the region traversed by Richardson and Drummond. Our specimens agree in every particular with his description of $O$. foliolosa until the fruit is reached, the "rather remote, deflexed" legumes, "an inch long" are those of $O$. deflexa, while "compact broadly ovate heads" could not refer to

* These numbers refer to the herbarium of the Geological Survey of Canada. 
that species. These fruiting specimens of $O$. defexu were also probably included in giving the range of $O$. foliolosi.

$O$. foliolosa is from + to 7 inches high, occasionally somewhat decumbent; legumes 3-5 lines long, clothed with black hairs, pendent, but when as in flower forming a compact head; otherwise as described by Hooker. From its habit and range it is evidently a high alpine and northern species.

Our herbarium specimens are from Northern Labrador, Herb. No. 18,668. (A. P. Low.) Rocky Mountains. (John Macoun.) Arctic North America (Dr. Richardson.)

These latter are young flowering specimens and were distributed from the British Museum as $O$. folzolosa.

Cassia Marilandica, L.

Two or three plants near the Thames River, east of Thamesville, Ont., 1892 ; on flats of Cornwall's Creek, Howard Township, Kent Co.; Aug. I5th, I892, well established; around the mouth of a government ditch, Tilbury, Ont., I 894. ( $J$. Dearness.) New to Canada and perhaps indigenous in S. W. Ontario.

Lathyres Maritimes, Bigel. var. Alectices, Greene.

A not rare variety on the Labrador coast and on both sides of Hudson Bay. Described from Alaska where, as on Hudson Bay, it is not mixed with, but in many localities takes the place of $L$. maritimus. The smaller size of the variety is not in my opinion due to habitat as L. maritimus of large size is found in equally exposeu situations in the same latitudes.

Dryas integrifolia, Vahl.

Summit of Moose Mt., Elbow River, Rocky Mts. Alt. $7,500 \mathrm{ft}$. Herb No. 20,00I. (John Macoun.) Southern limit in Rocky Mountains.

Alchemilla vulgaris, L.

Metis, Que., I897. (Mrs. Brodie.) Not recorded west of Nora Scotia.

Rosa Pratincola, Greene, Pittonia, vol. Ir, p. 13.

One of the commonest, if not the most common, roses on the Canadian prairies, extending from Manitoba west to the Rocky 
Mountains and north to the Saskatchewan. There is no R. Arkansana in Canada.

Rosa Macouni, Greene, Pittonia, vol. IV, p. Io.

R. Woodsii. Macoun, Cat. Can. Plants, vol. I, p. $5^{2} \mathrm{I}$ in part.

Moosejaw, Assa. Herb. No. I 2,615, in flower June I 7 th, 1896 ;

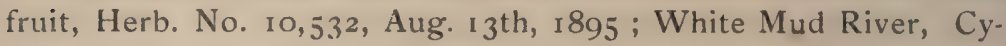
press Hills, Assa., Herb. No. 10,535; Cypress Lake, Assa., Herb. No. 10,534; Spur Creek, Milk River, Assa., Herb. No. 10,533; Canmore, Kananaskis and Bauff, Rocky Mountains. (John Macoun.) Maligne River, Athabasca River, Alberta, Herb. No. 19,45 I. ( $W$. Spreadborough.) Specimens from nearly all the above localities were named $R$. Woodsii by Crepin, but we have no $R$. Woodsi in Canada.

Tolmiea Menziesii, T. \& G.

Dawson Harbor. Queen Charlotte Islands, B. C. (Dr. C. F. Nerucombe.) Cowichan Lake, Vancouver Island. (J.R. Anderson.) Not before recorded from Vancouver Island.

Heuchera cylindrica, Dougl.

Dawson Harbor, Queen Charlotte Islands, B. C. (Dr. C. F. Nerocombe.) A new station.

Heuchera PARvifolia, Nutt.

Open prairies, Crow's Nest Pass, Rocky Mts. Herb. No. 20,167. (John Macoun.) Western limit.

Ribes Leucoderme, Heller, Bull. Torr. Bot. Club, vol. xxiv, p. 93.

Nearly all our specimens from Southern Alberta referred to $R$. oxycanthoides are this species.

Drosera longifolia, L.

D. Anglica, Huds. ; Macoun, Cat. Can. Plants, vol. I, pp. I65 \& 529.

D. intermedia, var. Americana, Macoun, Cat. Can. Plants, vol. 1, pp. 166 \& 529 in part; Contr. to Can. Bot. Pt. x, p. 273.

Throughout subarctic Canada. Our specimens are from east branch of Hamilton River, Labrador. Herb. No. 4998. (A. P. 
Lor., Salt Lake, Anticosti, Que.; Lake Huron, Ont.; Porcupine Mts., Man.; Prince Albert, Sask. ; Revelstoke, B. C.; Beaver Creek, Selkirk Mts., B. C.; Horne Lake, Vancouver Island. (John Mucoun.) Tete Jaune Câche, headwaters of Fraser River, B. C. (W. Spreadborough.)

Megarrhiza Oregana, Torr.

Union Bay, Saanich, Vancouver Jsland, $14^{\text {th }}$ July I 898 . ( $J$. R. Anderson.) New to Canada.

Galium mollugo, L.

St: James' Cemetery, Toronto, Ont., 1897. (IV. Scoll.) Only Ontario station.

\section{Aploppappus Lyallit, Gray.}

Mt. Cheam, Lower Fraser, B. C., I898. (J. R. Anderson.) Western limit.

\section{Solidago Purshit, Porter.}

S. humilis, Macoun; Cat. Can. Plants, vol. 1, p. 213 in part.

Our only specimens of this species were collected in $188_{3}$, at South West Point, Anticosti, Que., by Prof. Macoun. All the other references under $S$. humilis in the Catalogue of Canadian Plants should probably go to $S$. decumbens, Greene.

Aster Engelmanni, Gray.

Brazeau River, North Saskatchewan River, lat. $52^{\circ} 40^{\prime}, 1898$. (IV. Spreadborough.) Northern limit.

\section{Arnica Parryi, Gray.}

Headwaters of Fraser River, Yellowhead Pass, Rocky Mountains, 1898. ( $W$. Spreadborough.) Northern limit.

\section{Arnica tomentosa.}

- Stems clustered, three inches to a span high, simple and generally monocephalus, radical leaves oblanceolate or spatulate, con. spicuously 3 -nerved, loosely villous or sometimes tomentose; cauline, lanceolate or linear-lanceolate, villous-tomentose : involucre 
and peduncle wooly-tomentose ; rays, numerous, short : achenes hirsutulous ; pappus soft, white, barbellate.

Not rare on the eastern slopes of the Rocky Mountains, at high altitudes, between the International Boundary and Lat. $54^{\circ}$. Distributed from the Herbarium of the Geological Survey of Canada, under numbers $11,606,14,708$ and 19,635 .

Senecio Robinsir, Oakes.

S. aureus. L. var. lanceolatus, Oakes ; Macoun, Cat. Can. Plants, vol. I, p. 265.

A well defined species, easily separable from $S$. aureus and all its varieties. Rare on Cape Breton Island, N. S. The only specimens found by Prof. Macoun in 1898 , were at Biy Intervale, Margaree, and in woods at Baddeck.

Vaccinium Pennsylvanicum, Lam. var. angustifolium, Gray.

Macoun, Cat. Can. Plants, vol. i, p. 290.

Union Road, Prince Edward Island; in bogs, Louisburg, Cape Breton Island. (John Macoun.) Recent explorations have shown this plant to be widely distributed in Labrador.

Pterospora Andromeda, Nutt.

A new locality for this widely distributed but seldom collected plant is Tête Jaune Câche, headwaters of Fraser River, Rocky Mountains. ( $W$. Spreadborough.)

Bartonia IOdAndra, Robinson.

Holyrood, Newfoundland. (Robinson \& Schrenk.) Grand Lake, Newfoundland. (A. Wrghorne.) These records in Botanical Gazette, vol. xxvi, p. 47. In a bog six miles from Half Way House, Cape Breton Island, N. S., Aug. 5th, 1898 . Herb. No. 19,857. (John Macoun.)

VERBENA STRICTA, Vent.

Along the Grand Trunk Railway embankment at Stamford, Ont., 1898. (R. Cameron.) St. David's, Ont., 1898. (IV. Scolt.) New to Canada. 


\section{VERBASCUM BLATtARIA, L.}

Roadsides, Mira Bay, Cape Breton Island, N. S. (John Macoun.) Not recorded east of Ontario. These specimens are the subspecies $V$. virgatum, with very glandular shortly decurrent upper leaves, and pedicels shorter than the calyx.

Pedicularis capitata, Adams.

Moose Mountain, Elbow River, Rocky Mountains, alt. 7,000 ft., 1897. Herb. No. 19,916. (John Macoun.) Mountains near Lac Brulé, Athabasca River, Alta. Herb. No. 19,917, 1898. (IV. Spreadborough.) Not before recorded from Rocky Mountains, or south of the Arctic Circle in Canada.

Plantago eriopoda, Torr. var. cylindrica,

Maligne River, Athabasca River, Alberta, July 6th, 1898. Herb. No. 20,073. ( $\mathrm{W}$. Spreadborough. )A span high, leaves and scape pubescent, spike $3_{4}^{3} 1 / 4$ inch long, cyclindrical. This is probably $P$. lanceoluta, var. $B$., Hook, Fl., vol. ii, p. 123, and very likely a good species.

\section{Myrica Carolinensis, Mill,}

M. cerifera, Macoun, Cat. Can. Plants, vol. I, p. 435 .

Common on Prince Edward Island, Cape Breton Island and in parts of Nova Scotia and New Brunswick. . . ceriferu is not found north of Maryland, U. S.

LaRix Lyal.li, Parlat.

Between Kootanie Lake and the St. Mary's River watershed, B. C., at altitudes between 6,500 to 7,000 feet, or a little more, I898. (Samuel S. Fowler.) Western limit.

Lilium Columbianum, Hanson.

Tete Jaune Câche, headwaters of Fraser River, Rocky Mountains. 1898. ( $W$. Spreadborough.) Northern and eastern limit.

Lysichiton Kamtschatcense, Schott.

Wet woods near Canoe River, western slope of Rocky Mountains in Lat. $53^{\circ}$. 1889. ( $W$. Spreadborough.) Eastern and, in that part of Canada, northern limit. 
'Scripus RUfus, (Huds.) Schrad.

Marshes on summit of Smoky Mountain, Cape Breton Island, N. S., 1899. (John Macoun.) Not before recorded from Nova Scotia.

Scirpus SUbTERminalis, Torr.

In Fresh-water Pond, North Ingonish, and summit of Smoky Mountain, Cape Breton Island, N. S., 1898. (John Macoun.) Not recorded from Nova Scotia.

Carex costellata, Britt.

Edge of willow thickets near St. Catherines, Ont., 1898. ( $W$. C. McCalla.) The only Canadiau specimens we have seen.

Carex Crawei, Dewey.

Damp meadows, Baddeck, (Herb. No. 20,810), and Smoky Mountain, (Herb. No. 20,8 I I). Cape Creton Island, N. S, 1898. (John Macoun.) Not before recoided from Nova Scutia.

Eragrostis CAPILlaris, Nees.

A weed in a peach orchard, near St. Catherines, Ont., 1898. (W. C. McCalla.) New to Canada.

Glyceria villfoidea, Fries.

Near Prince George's Sound, Hudson Strait, 1897 . (Dr. R Bell.) Very abundant on saline mud, St. Paul Island, Behring Sea. (J. M. Macoun.) Not before recorded except from Greenland.

Aspinium Oreopteris, Swartz.

Shawnigan Lake, Vancouver Island, August, 1897. (J.R. Anderson.) One of our rarest ferns and not before collected on Vancouver Island.

Aspidium aculeatum Swartz. Var. scopulinum, D. C. Eaton.

Amongst rocks near the sea, Texada Island, Gulf of Georgia, B. C., Aug. 1897. ( $J, R$. Anderson.) Not before found in Canada west ff Province of Quebec, but collected in Washington, U. S. Woodivardia radicans, Smith. Var. Americanum, Hook.

Rich soil amongst hummocks, Texada Island, Gulf of Georgia, Aug. B. C. 1897 (/. R. Anderson.) New to Canada. 




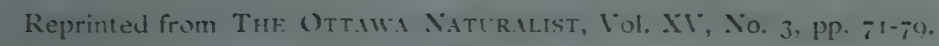
June, rgor, Ottawa, Canada.

CONTRIBUTIONS TO CANADIAN BOTANY.

$\mathrm{Br}$

James M. Macoun. 

Reprinted from THE OTt.1W X.ITtralist, Vol. XT, No. 3, pp. 71-79, June, 1901, Ottawd, Canada.

\section{CONTRIBLTIONS TO CANAD!AN BOTANY. ${ }^{1}$}

By JAMes M. M.ıcous, Assistant Naturalist, Geological Survey of Canada.

\section{XIV.}

Thalictrum confine, Fernald, Rhodora, vol. il, p. 232.

Rootstock 2 to $4 \mathrm{~cm}$. long, bearing ro to 12 strong roots: stem slender, 3 to $6 \mathrm{dm}$. high, puberulent, pale-green, often finely mottled with purple, leafy to the summit: the four or five leaves glandular-pruinose, glaucous beneath, the lower, including the short petiole 3 to $4 \mathrm{~cm}$. long; leaflets suborbicular broadly obovate or fiabellate, coarsely toothed, 0.75 to $1 \mathrm{~cm}$. long, the terminal on slender petiolules, the lateral short-petiolulate or subsessile : flowers dicciolis, greenish or purplish, the panicles 1 to $2 \mathrm{dm}$. high, with ascending branches: sepals greenish, oblong-lanceolate, caducous : carpels 6 to 10 , glandular-pruinose ; stigmatose style lance-subulate, 3 to $5 \mathrm{~mm}$. long; achenes ovate-lanceolate, excluding the persistent style, 4 to $5 \mathrm{~mm}$. long, 2 to $3 \mathrm{~mm}$. thick, plump, subterete, scarcely compressed or ancipital with 8 simple or slightly branched strong ribs, the alternate ones strongest; seed linear-lanceolate, hardly filling the cell.

Thickets, Hemlock Lake, near Ottawa, Ont., in flower, Aug. 8th, 1894. Herb No. 2,956.2 (John Macoun.) Also collected in Maine.

\section{Thalictrum occidentale, Gray.}

T. dioicum purpurascens, Can. Rec. Sci, I 894, p. 77.

Rootstock slender, elongated: stem glabrous, I m. or less high, leafy to the summit, the three to six leaves glaucous beneath, smooth or minutely glandular, the lower including the long petiole 0.5 to $3 \mathrm{dm}$. long, those of the inflorer :e often simple; leaflets thin, reniform or obovate, with coarse rounded lobes, the terminal on slender petiolules, the others

1 Published by permission of the Director of the Geological Survey of Canada.

2 These numbers are those under which specimens have been distributed from the Herbarium of the Geological Survey of Canada. 
short-petiolulate or sub-sessile: flowers dicecious or polygamo. diœecious, greenish or purplish, the panicles 1.5 to $3 \mathrm{dm}$. high, with ascending branches: sepals oblong: carpels glabrous or minutely glandular-pruinose; achene excluding the persistent style 6 or $7 \mathrm{~mm}$. long, 2 or $3 \mathrm{~mm}$. wide, compressed, strongly ancipital, with three strong or somewhat branching ribs on each side: filaments yellowish, greenish, or purplish, elongated, slightly clavellate; anthers linear, mucronate.

Represented in the herbarium of the Geological Survey of Canada by many sheets from the west and by specimens collected at Eel River, N.B., by Robert Chalmers, and on the St. John River above Woodstock, N.B., by John Macoun. Mr. Fernald has examined specimens collected by Mr. G. U. Hay at South Tobique Lakes and St. John, N.B., and by Bourgeau near Lake Winnipeg.

Ranunculus Pallasil, Schlecht.

Mosquito Bay, Lat. $60^{\circ} 42^{\prime}$, east coast of Hudson Bay. Aug. 18th, 1898. Herb. No. 23,003. (A. P. Low.) Not recorded from Eastern America.

Berberis brevipes, Greene, Ott. Nat., vol. xv, p. 42.

Crow's Nest Pass, Rocky Mts., 1897. Herb. No. 18,080. (John Macoun.)

Sarracenia purpurea, L. var. heterophylla, Torr.

In bogs, Madawaska River, Algonquin Park, Ont. 1900. (John Macoun.) Only Canadian specimens in herbarium of Geological Survey.

Dentaria geminata, Wats.

Koksita, Vancouver Island. (R. H. Jameson.) New to Vancouver Island.

Viola mistassinica, Greene, Pittonia, vol. iv, p. 6.

Lake Mistassini, Que. 1885 . (J. M. Macoun.) Richmond Gulf, Hudson Bay. ( Wm. Spreadborough.) West branch of Hamilton River, Labrador. (A. P. Low.) Banff, Rocky Mountains. (N.B. Sanson.) Cassiar Trail, west of Dease 
Lake, B.C. Lat. $5^{8^{\circ}} 30^{\prime}$. (Dr. G. M. Dazuson.) The western specimens differ slightly from those from the east, but seem referable here. This plant is readily distinguished from $V$. blanda, $V$. renifolıa, and $V$. amoena by its "stout scaly-looking and elongated root-stock and by its notably toothed foliage, the leaves in all the others being crenate, the proper teeth never salient but on the contrary almost obselete." The lowest petal is not only purple-veined but the purple colour is diffused over the whole petal.

Vrola Watsoni, Greene, Pittonia, vol. Iv, p. 5.

Boggy meadow near Charlottetown, P.E.I. 1898. (Lawrence $W$. Watson.)

Viola cyclophylla, Greene, Pittonia, vol. IV, p. 7 .

Yellow Head Pass, Rocky Mountains, July 1 $3^{\text {th, } 1898 .}$ Herb. No. 19,298. The type. (W. Spreadborough.)

Stellaria subvestita, Greene, Ott. Nat., vol. xv, p. 42.

Common in the Rocky Mountains on both sides of the Bow River Pass.

Stellaria media, Cyrillo.

Attention is again drawn here to Mr. Theo. Holm's paper on "Allies of Stellaria media" in the last number of THE OtTawa Naturalist. These plants should be carefully studied everywhere in Canada. Among our herbarium specimens labelled $S$. media, S. neglecta was found from Victoria, Vancouver Island; Burrard Inlet, B.C., Killarney, Man.; Sable Island, N.S.

Radiola linoides, Gmel.

Along a ditch near the old fortifications at Louisburg, Cape Breton Island, N.S. 1898. Herb. No. 20,232. (John Macoun.) New to Canada. Probably introduced by the French.

Spiráa salicifolia, L.

The reading of Mr. Wiegand's note on S. salicifolic in Rhodora for May, 1900, suggested an examination of the 
sheets in the herbarium of the Geological Survey of Canada. This examination has forced me to the conclusion that we have no true $S$. salicifolic in Canada. There are, however, three or four well defined varieties or species of which the most abundant in the east is S. salicifolia, var. latifolza, Ait., common from Nova Scotia to Lake Superior but not found in the Northwest. Territories. The form most nearly approaching. S. salicifolia is var. lanceolata, Ait., represented in our herbarium by specimens from Newfoundland west to Prince Albert on the North Saskatchewan. Though the herbarium material is ample no attempt will be made at present to characterize the other forms as like some other genera of the Rosacea, Spirce must be studied in the field. The part of the plant which can most easily be made into a herbarium specimen is not always that most necessary for the proper determination of the species.

Agrimonia hirsuta, Bicknell.

A. Eupatoria, Macoun, Cat. Can. Plants, vol. I, p. 142 in part.

Truemanville, N.S. (H. Trueman.) Billings' Bridge, Ottawa, Ont. ; Pt. Edward, St. Clair River, Ont. ( $/ . M$. Macoun.) Belleville, Ont.; Wooler, Northumberland Co., Ont. (John Macoun.) Edmonton, Ont. (Jas. White.)

Agrimonia Brittoniana, Bicknell.

Boylston, N.S. (Dr. C: A. Hamilton.) Big Intervale, Cape Breton Island, N.S.; Flat Rock Portage, Nipigon River, Ont.; Killarney, Man. (John Maconn.) The western specimens in the herbarium of the Geological Survey include several species.

MYriophyllum Alterniflorum, D.C.

Golden Lake, Renfrew Co., Ont. (John Macoun.) The western limit of this seldom collected species. ${ }^{1}$

Triosteum aurantiacum, Bicknell, Torreya, vol. I, p. 26.

Rich soil on the rocky bank of the Nation River at 
Casselman, Ont. (J. M. Macoun.) T. perfoliatum is represented in the herbarium of the Geological Survey by specimens from Belleville and Churchville, Ont.

Eupatorilim boreale, Greene, Rhodora, vol. ili, p. 83 .

Stout, erect, 2 feet high or more, glabrous except as to the inflorescence : leaves ample, very thin, dark-green, featherveined, the veins not light-coloured, 3 or 4 inches long, often 3 inches broad towards the base, broadly subcordate-ovate, abruptly acuminate, coarsely and evenly serrate, the serratures 20 to 25 on each side, some of the larger with a secondary tooth; petioles $3 / 4$ to $1 / 1 / 2$ inches long, somewhat ascending: cymes terminal, but with one pair from the axils of the uppermost leaves: peduncles and pedicels rather densely pubescent, but involucres glabrous, their bracts thin, only obscurely striate: tips of the corolla-teeth somewhat hairy: achenes dark-brown, sharply thin-angled, the angles of those of the outer series remarkably setose-hispidulous, the surface glabrous.

Represented in our herbarium by specimens from Bass River, Kent Co., N.B., collected by Prof. J. Fowler. Most of what has heen taken to be $E$. ageratoides in Eastern Canada is probably this species.

Solidago prlinosa, Greene, Pittonia, vol. 1\%, p. 70.

Erect, ; feet high or more, very leafy up to the dense short, pyramidal panicle of short, spreading or slightly recurved abruptly ending and obtuse racemes of rather large heads: leaves ascending, 2 inches long, elliptic-lanceolate, acute or acuminate, slightly but evenly serrate from near the base to near the apex, distinctly 3 -nerved and canescent or almost hoary on both faces with a dense, rather soft pu'jerulence or pubescence: pedicels and branches of the inflorescence almost tomentulose : bracts of the more than middle-sized involucre in about 3 series, the short outer ones subulate-linear, the inner long ones also visibly narrowed from base to apex but obtusish; flowers apparently light yellow.

Moose Jaw, Assa., Aug. $3^{\text {th, }} 1895$. Herb. Nos 10,892 , 10,893 and 10,894 .

(John Macorn.) 
Eucephalus macounir, Greene, Pittonia, vol. iv, p. 70.

Along fences, Sea's Farm, near Victoria, Vancouver Island. Herb. No. 447. (John Macoun.) Distributed as Aster radulinus.

Centaurea Scabiosa, L.

Along the Canadian Pacific Railway at Snellgrove, Ont. (Jus. White.) New to Canada and known from only one other locality in America. Determined by Dr. Robinson.

Senecio ovinus, Greene, Pittonia, vol. iv, p. I Io.

S. resedifolius, Macoun, Cat. Can. Plants, vol. I, p. 267 in part.

Mountain slopes, western summit of North, Kootanie Pass, Rocky Mts., 1883. (Dr. G. M. Dareson.) High slopes of Sheep Mountain, Waterton Lake, Rocky Mts. Herb. No. I 1,619. (John Macoun.) Described from the Sheep Mountain specimens.

VACCINIUM NigRUM, Britt.

V. corymbosum, var. pallidum, Macoun, Cat. Can. Plants, vol. I, p. 29 I.

Point Pleasant, N.S.; Englishtown, Cape Breton Island, N.S.; common in the vicinity of Ottawa, Ont., and at Niagara, Ont. (John Macoun.)

Lysimachia vUlgaRis, L.

Well established on Toronto Island, Ont. (W. Scott.) Only Canadian record.

Steironema lanceolatum, Gray; Macoun Cat. Can. Plants, vol. I, p. 3i3.

Recorded from Ontario, but such specimens as we have seen so named are S. quadriflorum, Hitchc.

Acerates longifolia, Ell.

Dry sandy soil, southwest of Sandwich, Ont., 1893. (Alex. Wherry.) Our only Canadian specimens. The specimens referred here, Macoun, Cat. Can. Plants, vol. I, p. $5^{6} 3$, are $A$. viridiflora var. lanceolata, $\mathrm{Gr}$. 
Asclepias pulchra, Ehrh.

In Mahone River bed at New Germany, N.S., and at entrance of West River into New Germany Lake, N.S., July 1891. Herb. No. 23.581. (Dr. C. A. Hamilton.) New to Canada.

Erythrea Centaurium, Pers.

Very abundant on the old land near the main lighthouse station, Sable Island, N.S. I899. (John Macoun.) Our only Canadian specimens.

Lithospermum Latifolium, Mx.

Lorette Falls, near Quebec, Que. 1895. (Mrs. Brodie.) Not before recorded except from Ontario.

Heliotropium. Curassavicum, L.

Saline soil, McLeod, Alta. Herb. No. 23,97I. (John Macoun.) Western limit.

Convolvulus arvensis, L.

Open prairies, Morris, Man. (John Macoun.) Not recorded from Manitoba.

Physalis IXocarpa, Brot.

Roadsides near the hotel, Golden Lake, Renfrew Co., Ont. (John Macoun.) New to Canada.

Hyoscyamus Niger, $L$.

Old railway ground, Banff, Alberta. igoo. (N. B. Sanson.) Not before recorded from the west.

Buchnera Americana, L.

Port Frank, Ont., Sept. 8th, 189r. ( $/$ Dearness.) Only Canadian record.

Gerardia paupercula, Britt.

In marshy places near the main station, Sable Island, N.S. 1899. Herb. No. 22,578. (John Macoun.) Not recorded east of Quebec.

Lippia lanceolata, Mx.

Wet places, Leamington, Ont. I 892. Herb. No. 24,270. (John Macoun.) New to Canada. 
Amarantus blitoldes, Wats.

East of Brandon, Man.; Cardston, Alta. (John Macoun.) Not recorded west of Ontario.

Monolepis chenopodioides, Moq.

Cypress Hills, Assa.; Kananaskis and Banff, Rocky Mts. (John Macoun.). Western limit.

Chenopodium Botrys, L.

Waste places, Spence's Bridge, B C. (John Macoun.) Not recorded west of Ontario.

Chenopodium leptophyllum, Nutt.

Sandy suil, Spence's Bridge, B.C.; Deer Park, Lower Arrow Lake, B.C. (John Macoun.) Not recorded west of Rocky Mountains.

Chenopodium leptophyllum. Nutt, var. subglabrum, Wats.

Sandy woodlands, Pt. Pelee, Essex Co., Ont. I886. (Dr. Burgess.) Neither the type nor variety recorded from Ontario.

Chenopodium urbicum, $\mathrm{L}$.

Nanaimo and Victoria, Vancouver Island, B.C. I 893. (John Macoun.) Not recorded west of Ontario.

Chenopodium RUbrum, $L$.

On brackish flats near the main lighthouse station, Sable Island, N.S. Very rare. I898. (John Macoun.)

Salicornia herbacea, L.

Borders of saline ponds near Kamloops, B.C. 1890. (J. M. Macoun.) Not recorded from British Columbia.

Salicornia ambigua, Mx.

Long Arm, Skidegate Inlet, Queen Charlotte Islands, B.C. (Dr. C. F. Nerocombe.) Northern limit.

Rumex Patientia, L.

Not uncommon about houses and in fields, Boylston, N.S. (Dr. C. A. Hamilton.) Not recorded east of Ontario.

Scleranthus anvuus, L.; Macoun, Cat. Can. Plants, vol. I, pp. 80 and 499.

West of London, Ont., I890; Komoka, Ont., July, 1892. ( $J$. Dearness.) Our only herbarium specimens. 
Podostemon Ceratophyllum, Mx.

On stones near the mouth of Eel River, 12 miles below Woodstock, N.B. Herb. No. 22,593, I899; Petawawa River, Algonquin Park, Ont., 1900. (/ohn Macoun.) Our only other specimens are from Hull, Que.

Cypripedium guttatum, Swartz.

Shore of Great Slave Lake, 1899. (Dr. R. Bell.). The single specimen brought home by $\mathrm{Dr}$. Bell is the third from the Mackenzie Basin, the others having been collected by Richardson.

Cypripedium passerinum, Rich.

West shore of Great Bear Lake, Lat. $65^{\circ} 30^{\prime}$ to $66^{\circ} 30^{\prime}$. 1900. (J.M. Rell.) Northern limit.

Zygadenus elegans, Pursh.

West side of Great Bear Lake, Lat. $65^{\circ} 30^{\prime} 1066^{\circ} 30^{\prime}$. 1900. (J.M. Bell.) Northern limit.

Juncus Bulbosus, L.

In boggy places, east end of Sable Island, N.S. 1899. Herb. No. 22,623. (John Macoun.) Only Canadian specimens in herbarium of Geological Survey. Reported from Labrador.

Stenophyllus capillaris, (L.) Britt.

Wet sandy fields, Sandwich, Ont. Herb. No. 25.334. (John Macoun.) New to Canada.

Fimbristylis autumalis, R. \& S.

Wet sandy fields, Sandwich, Ont. Herb. No. 25.333. (John Macoun.) New to Canada. Growing with Stenophyllues capillaris.

Carex Leiocarpa, C. A. Meyer; Macoun, Cat. Can. Plants, vol. II, p. I Io.

Dawson' Harbour, Skidegate Inlet, Queen Charlotte Islands, B.C. (Dr. C. F. Nerucombe.) The second Canadian station.

Carex capitata, L.

Additional stations for this species are Northern Labrador. (A. P. Low.) Boggy places, Bragg's Creek, Elbow River, Rocky Mountains. Herb. No. 25,47. (John Macoun.) 



[Reprinted without change in paging from THE OtTAwa NatrRaList,

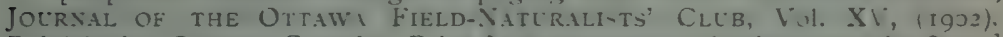
Publishedat Ottawa, C.unada Price \$1.0o per year; tolureigrn countries \$i.2j]

\section{CONTRIBUTIONS TO CANADIAN BOTANY.} $\mathrm{XV}$.

By

JaMES M. Macoun。 

[Reprinted without change in paging from THE OTTAWA NATURAList, jotrnal of the Ottawa Field-Natcralists Cleb, Vol. XV, (igoz). Published at, Ottawa, Canada. Price \$I.00 per year; to foreign countries \$I.25]

\section{CONTRIBUTIONS TO CANADIAN BOTANY. 1}

By James M. Macoun, Assistant Naturalist, Geological Survey of Canada. XV.

Anemone Hudsoniana, Rich.

Frenchman's Bay, near Southampton, Ont. Aug. 28th, Igo 1. (John Macoun.) Southern limit in Ontario.

Aquilegra coccinea, Small.

Niagara, Ont.; Câche Lake, Algonquin Park, Ont. ; Otterburne, Man.; Brandon, Man. (John Macoun.) Wingham, Ont. (J.A. Morton.) Grindstone Point, Lake Winnipeg. (J.M. Macoun.) Our only specimens of $A$. Canadensis are from Ottawa, Belleville and Red Rock, Ont. A. coccinea is easily separable from $A$. Canadensis either in flower or fruit. In flower by its stout spur which is more than twice the length of that of $A$. Canadensis and abruptly narrowed near the apex. The follicles of $A$. coccinea are straight and much longer than the spreading follicles of $A$. Canadensis.

Aquilegia vulgaris, $L$.

Roadside, Wyoming near Petrolia, Ont. (John Macoun.) Lesquerella nodosa, Green, Pittonia, vol. IV, p. 309.

On sand, Castellated Rocks, Milk River, Assa., July i $3^{\text {th, }}$ 1895. Herb. No. 10,31.3. ${ }^{\overline{2}}$ (John Macoun.)

Lesguerella versicolor, Greene, Pittonia, vol. IV, p. 3 ro.

On rocky slopes, Stony Mt., Man., June 4th, 1896. Herb. No. 1 2,401. (John Macoun.)

Lesquerella Macounil, Greene, Pittonia, vol. iv, p. 310.

On prairies at the police barracks, Medicine Hat, Assa., Aug. 9th, 1895. Herb. No. I0,308. (John Macoun.)

I Published by permission of the Director of the Geological Survey of Canada.

${ }^{2}$ These numbers are those under which specimens have been distributed from the Herbarium of the Geological Survey of Canada. 
Lesquerella rosea, Greene, Pittonia, vol. iv, p. 310.

On prairies at Old Wives' Creek, Assa., June 2nd, r 895. Herb. No. 10,309. (John Macoun.)

Brassica juncea, Cass.

Montrose, near Niagara, Ont. (R. Cameron.) Burnside Road, near Victoria, Vancouver Island. (A.J. Prneo.)

Viola Fletcheri, Greene, Pittonia, vol. IV, p. 296.

Acaulescent, small, the simple ascending rootstock rather small for the plant, closely jointed: leaves few, small, from ovate-reniform to subcordate-ovate, $3 / 4$ to $\mathrm{I}$ inch long at time of petaliferous flowering, the undeveloped ones cucullate, all very regularly crenate, glabrous and shining above, mostly sparsehirsutulous beneath and on the petioles, these in the earliest not longer than the blade, in the later more than twice as long: flowers very few, often I only; peduncles hirsute, minutely bracted below the middle : sepals small, lanceolate, veinless, serrate-ciliolate: corolla large, more than $3 / 4$ inch broad, rich purple; the upper pair of petals much the largest, obovate, the middle pair narrower in proportion and strongly bearded with long cylindric hairs, the odd one as long asthese and a trifle broader.

Growing with $V$. blanda under trees north of the road running from Rockcliffe to Beechwood. The plants grow singly and are generally one-flowered. Collected in the spring of I90 I and in fruit in September by Dr. J. Fletcher and J. M. Macoun.

Viola subviscosa, Greene, Pittonia, Vol. IV, p. 293.

Rootstocks not much branched, slender, short-jointed and knotted; plant 4 to 5 inches high at time of petaliferous flowering: leaves thin, deep-green, shining and slightly clammy, very sparsely appressed-hairy above, somewhat hirsute beneath along the veins and sparsely ciliate, in outline from cordate-reniform to broadly cordate with deep and often almost closed sinus, subserrately crenate, the more strictly cordate ones about 2 inches in diameter and little longer than broad: peduncles about equalling the leaves, bibracteolate 
below the middle, more or less strongly hirsutulous, as are also some of the petioles : sepals oblong, obtuse, strongly and closely ciliate with spreading or somewhat retrorse hairs: corolla violet, large, about $11 / 4$ inches wide, the petals not very dissimiliar, rather broadly obovate, the keel as broad as the others and very obtuse.

Described from specimens collected by Dr. Jas. Fletcher, in open spaces among woods at Aylmer, Que. This species has also been collected on Prince Edward Island, by Mr. L. W. Watson and in Vermont. In general appearance $V$. subviscosa resembles $V$. seplentrionalis but this latter species " has a heavier foliage, of a light green shade, wholly devoid of clamminess, each leaf with a broad open sinus and each branch of its stout rootstock produces a considerable cluster of leaves and flowers."

Viola cardaminefolia, Greene, Pittonia, vol. iv, p. 289.

Caulescent, the numerous slender decumbent or more depressed stems 3 to 5 inches long: leaves small, the subcordate-ovate obtuse minutely crenate blade often merely $1 / 2$ inch, seldom $3 / 4$ inch long, of firm texture, obscurely pulverulent-puberulent, the slender petioles about I inch long; stipules lanceolate, the lowest serrate-ciliate, the upper nearly entire except toward the base : slender peduncles little more than an inch long, bibracteolate much above the middle: sepals subulate-lanceolate, glabrous : corolla small, deep-blue; spur elongated, oblique.

In rocky woodland near Aylmer, Quebec, Canada, 6 June, I90 I, Dr. J. Fletcher. Allied to the common $V$. Muhlenberguana of the U. S. (now rightly or wrongly called $V$. Labradorica), but easily distinct by its small, thick and somewhat fleshy foliage always of ovate outline and obtuse ; the flowers not half as large, much more deeply coloured, with a different spur.

Viola fulcrata, Greene, Pittonia, vol. IV, p. 285.

Cowichan River, Vancouver Island, 2 June, 1898 . Herb. No. 19,912. (J.R. Anderson.): 
Viola petrophila; Greene, Pittonia, vol. iv, p. 286.

Crevices of rocks, Shawnigan Lake, Vancouver Island, 9 May, I897. '(J.R. Anderson.)

Viola compacta, Greene, Pittonia, vol. Iv, p. 286.

Crevices of rocks, Shawnigan Lake, Vancouver Island. Herb. No. 19,910. (J.R. Anderson.)

Viola Andersonir, Greene, Pittonia, vol. Iv, p. 287.

Thetis Lake, B. C., 29th April, 1900. (J.R. Anderson.)

Viola orecallis, Greene, Pittonia, vol. IV, p. 288.

Mill Hill, B. C., 28th April, 1900. (J.R. Anderson)

Vrola Albertina, Greene, Pittonia, vol. IV, p. 289.

Described trom spécimens collected by W. Spreadborough east of McLeod River, northern Alberta, but a common species everywhere in the foot-hills of the Rocky Mountains.

Cerastium angustatum, Greene, Pittonia, vol. iv, p. 300.

Open prairies in the sandhills north of Prince Albert, Saskatchewan, July, 1896. Herb. No. 12,459. (John Macoun.) Only known station.

Cerastium campestre, Greene, Pittonia, vol. iv, p. 30 .

The common species on the Canadian prairies. Our specimens are from Stonewall, Man. (John Macoun.) Indian Head, Assa. (W. Spreadborough) Cypress Hills, Assa. ( $J$ : M. Macoun.)

Cerastium vestitum, Greene, Pittonia, vol. IV, p. 302.

Dry banks at Ste. Anne, west of Edmonton, Alberta, June 9th, 1898. Herb. No. 19,285. (W. Spreadborough.) A well-marked species known only from Mr. Spreadborough is specimens.

Cerastium confertum, Greene, Pittonia, vol. iv, p. 302.

Described from specimens collected by Prof. John Macoun along the old telegraph trail in Lat. $54^{\circ}$, British Columbia, June 24th, I875, and at Stewart Lake, B.C., $\mathrm{Ju}$ ne 2oth. Not since collected. 


\section{ERASTIUM TOMENTOSUM, L.}

There are specimens of this species in the herbarium of the Geological Survey, labelled "Brant Co., Ont." but without the collectors' name. It is here recorded in the hope that some further information relating to it may be secured as this is the first American record known to us.

Mentzelia tenerRima, Rydberg.

Waneter, B.C. Igor. (R. H. Jamieson.) New to Canada.

Stenotus Lyalit, (Gray.)

On nearly all the higher mountains on both sides of the Chilliwack Valley, Coast Range, B.C., at about 6,00o ft. alt. Always found with Solidago multiradiata, var. scopulorum. (J. M. Macoun.)

Solidago Virgaurea, L., var. Gillmani, (A. Gr.) Porter.

On rocks at the extreme end of the Bruce Peninsula, Tobermory, Ont., Aug. 23rd, I901. Herb. No. 26,719. (John Macoun.) Known previously only from the south shore of Lake Superior. Probably a good species.

Solidago juncea, Ait, var. scabrella, A. Gray.

Thickets at Leamington, Ont. 1901. (John Macoun.) New to Canada.

Aster angustus, T. \& G.

At the "round house" in the M. C. Ry. yard at Montrose near Niagara, Ont. ( $R$. Cameron.) Introduced from the prairies.

Aster longifolius, Lam., var. villicaulis, Gray.

On earth along the St. John River at Woodstock, N.B. Herb. No. 22,505. (John Macoun.) Our only Canadian specimens.

Aster kentuckyensis, Britt.

Toronto Island, Ont., Sept. 6th, I901. Herb. No. 26,358. (John Macoun.) New to Canada. Determined by Dr. Britton. 
Aster vimineus, Lam., var. SAxatilis, Fernald, Rhodora, vol. I, p. 188 .

Paugan Falls, Que,; banks of the Nation River at Casselman, Ont. (John Macoun.)

Erigeron Brandegei, Greene.

Aplopappus Brandegui, Gray.

On mountains north of Chilliwack Lake, Coast Range, B. C., alt. 6,500 to 7,500 ft., 190I. (J.M. Macoun.) Not recorded west of Selkirk Mts. ${ }^{1}$

Gnaphalium uliginosum, L.

Abundant along ditches, Chilliwack, B. C., Igor. (J. M. Macoun.) Our only specimens from British Columbia.

Xanthium Pennsylvanicum, Wallr.

Common at Humber Bay in front of High Park, Toronto, Ont., 19or. Herb. No. 26,807. (John Macoun.)

Xanthium commune, Britt.

From Quebec to Manitoba. Our specimens are from Casselman, Ottawa and Napanee, Ont., and Brandon and Killarney, Man.

Xanthium Macouni, Britt.

Goose Island, Lake Winnipeg, Man., 1884. The type. (J. M. Macoun.) Only known station.

Xanthium glanduliferum, Greene.

Police Point, Medecine Hat, Assa. Herb. No. I o,9I I ; Walsh, Assa. Herb. No. 10,910, the type; east of Hand Hills, Alta. (John Macoun.)

$X$. echinatum and $X$. Canadense are not known to occur in Canada, but as they grow in the Northern States they will probably be found in Southern Ontario.

SilphiUm PERfoliatum, L.

Not rare at Chatham, Ont. (John Macoun.)

1 The geographical limits given in these papers refer to Canada only. 


\section{SILPHIUM TEREBINTHINACEUM, L.}

Walpole Island, St. Clair River, Ont. (C.K. Dodge.) In thickets at Sandwich and Windsor, Ont. (John Macoun.)

Helianthus Petiolaris, Nutt.

Along the C. P. Ry. at Câche Lake, Ont. I900. (John Macoun.) Introduced from the west.

Helianthus annuUs, L.

Head of Queen street, near High Park, Toronto, Ont. 1901. (John Macoun.)

Chrysanthemum segetum, $L$.

Near the tannery at Tilsonburg, Ont. 1901. (Macoun.) A garden escape. Not recorded from Ontario.

Chrysanthemum coronarium, $\mathbf{L}$.

A garden escape at Tilsonburg, Norfolk Co., Ont. (John Macoun.)

Artemisia caudata, Michx.

Abundant in sandy fields at Sarnia, Lambton Co., Ont. Collected in recent years by C. K. Dodge and by Prof. Macoun in 1901. Herb. No. 26,339. The plants from Manitoba referred here in Macoun's Catalogue of Canadian Plants, vol. I, p. 256, are A. Canadensis.

Artemisia Abrotanum, L.

Roadsides at Allenford between Southampton and Owen Sound, Ont. rgor. (Macoun.) Not before recorded in these papers.

Senecio Plattensis, Nutt.

Woods at Sandwich, Ont. Herb. No. 26,673, and at Camlachie, seven miles from Sarnia, Ont. Herb. No. 26,674, 1901. (John Macoun.) New to Canada.

Carduus Hillit, (Canby.) Porter.

On shingle, Little Eagle Harbour, Lake Huron. Aug. 23rd, I901. Herb. No. 26,454. (John Macoun.) Specimens referred to Cnicus pumilus, Macoun, Cat. Can. Plants, vol. I, p. 555 are this species. 
Saussurea monticola, Rich., App. Frank. Journ., ed. 2, 29.

Lumped with S. alpina by Gray and others, but it presents so little resemblance to that species that the most casual observer would at once know it to be distinct. Easily separated from S. alpina by its " narrower, more rigid entire leaves and very hairy involucre." Collected by Dr. Richardson in grassy plains on the Copper Mountains, lat. $67^{\circ}$, and along the arctic coast between the Mackenzie and Coppermine rivers. The specimens in the herbarium of the Geological Survey are from Herschell Island, west of the mouth of the Mackenzie, 1893. (Rev.J. I. Stringer.) West shore of Great Bear Lake, lat. $65^{\circ} 30^{\prime}$ to lat. $66^{\circ} 30^{\prime}$. I 900 . (J.M. Bell.) Lat. $62^{\circ} 17^{\prime}$, long. $103^{\circ} 07^{\prime}, 1893$; on Stony Island, Great Slave Lake, igoo. ( /. W. Tyrrell.)

Hieracium Pilosella, L.

St. John and Charlos, Restigouche River, N.B. (Philıp Cox.) New to New Brunswick.

Hieracium longipilum, Torr.

A single specimen collected in woods 5 miles from Sarnia, Ont. I901. (John Macoun.) A very rare species in western Ontario. Seldom collected.

Mentha rotundifolia, (L.) Huds.

In a gravelly ravine running into the Thames near London, Ont., 190r. (J. Dearness.) New to Canada.

Curnopodium Acinos, (L.) Kuntze.

Our herbarium specimens of this plant are from sandy and grassy roadsides north of London, Ont. ( $J$. Dearness) and near Galt, Ont. ( $W$. Herriot.)

Rumex fenestratus, Greene, Pittonia, vol. IV, p. 306.

Described from specimens collected by Prof. John Macoun in salt marshes at Comox, Vancouver Island, June 23rd, 1893. Herb. No. 1,570. Also collected in 1887 by Prof. Macoun at Chase River, near Nanaimo, Vancouver Island. Herb. No. 23,723. The common large Rumex on the east coast of Vancouver Island. 
1902] Macoun-Willows of the Chilliwack Valley, B.C. 275

Calamovilfa longifolia, (Hook.) Hack.

Ammophrla longrfolia, Macoun, Cat. Can. Plants, vol. II, p. 208.

Sand-dunes at Point Edward, Lake Huron, Ont. I90I. Herb. No. 26,047. (John Macoun.)

Danthonia Americana, Scrib. U.S. Dept. Agric. Div. Agros., Circular 30, p. 5 .

Wellington Mines, Nanaimo, Vancouver Island. June 13th, 1887. (John Macoun.) Among a score or more of sheets of Danthonia from the west coast of British Columbia, our herbarium contains but this one of $D$. Americana.

NOTES ON THE WILLOWS OF THE CHILLIWACK VALLEY, B.C.

By J. M. Macoun.

The number of species of Salix in the Chilliwack Valley is remarkably small for that region, only four species having been seen in I90I in the valley itself and five on the mountains on either side of it. In the valley $S$. Sitchensis is common everwhere, and was the only willow growing along the river between Chilliwack Lake and the point at which the river enters the Fraser Valley with the exception of one clump of $S$. pseudomyrsinites Anders., which grew on a gravel bar in the river. This species was also found by a rivulet at an altitude of 6,000 feet. The other valley species were $S$. caudata (Nutt.), collected at Chilliwack village, and S. Lyallii, Heller, at Sumas Lake and by a stream flowing into Chilliwack Lake. 
The only common species on the mountains was $S$. commutata, Bebb., always by rivulets at about 5,000 feet altitude, where snow has lain late in the spring. S. conjuncta, Bebb., was found on one mountain in a similiar habitat. S. nivalss, Hook., which might be expected to be common, was seen only on Tami Hy Mountain at an altitude of 5,500 feet. S. subcordata covered a large boulder at 5,600 feet and $S$. crassijulis, Trautv., was abundant on a rocky slope on Tami Hy Mt. but seen nowhere else.

Specimens of all the above were examined by Dr. P. A. Rydkerg who has verified my determinations and named the species about which I was uncertain.

\section{TARAXACUM IN CANADA.}

About a year ago Dr. Edw. L. Greene described several new species of Taraxacum from Canada.* Several sheets of specimens have been added to the Geological Survey collection since our material was examined by Dr. Greene, but these are all referrable to one or other of the species enumerated below. In his introductory note Dr. Greene says : "Indigenous species will probably be found sufficiently numerous though perhaps only upon western mountain territory." It is probably true that the number of indigenous species in eastern and northeastern Canada is small, perhaps, indeed, there is only one species which ranges from the mountains of eastern Quebec through Labrador and Ungava to Hudson Bay, but that there is at least one indigenous species in eastern Canada no one who has travelled through the unsettled

*Pittonia, Vol. IV, pp. 227-233. 
parts of the country can doubt. Not only is Taraxacum not rare on the banks of lakes and streams, but the writer has often found it in bogs and swamps several hundred miles from settlement of any kind.

Taraxacum Chamissonis, Greene, Pittonia, vol. IV, p. 228.

Very common on the shores and islands of Bihring Sea and south along the Alaskan coast. Will probahly be found in British Columbia.

Taraxacum rupestre, Greene, Pittonia, vol. 1V, p. 229.

Crevices of rocks, alt. 6,000 ft., Mt. Queest, Shuswap Lake, B C. Herb. No. 15,111; Avalanche Mt., Selkirk Mountains, B.C., alt. 8,000 ft. (J.M. Macoun.) Kicking Horse Lake, Rocky Mountains. (John Macoun.)

Taraxacum ovinum, Greene, Pittonia, vol. Iv., p. 229.

On Sheep Mountain, Waterton Lake, lat. $49^{\circ}$ o5', Rocky Mountains. Herb. No. II,7 II. (John Macoun.)

Taraxacum lacerum, Greene, Pittonia, vol iv, p. 230.

Canyon of the Upper Liard River, Yukon, lat. $60^{\circ} 26^{\circ}$. June, 1887. Herb. No. I5, I19. (John Macovn.)

Taraxacum dumetorum, Greene, Pittonia, vol iv, p. 230.

A common species from Assiniboia westward to British Columbia.

TARAXacum erYthrospermum, Andrz.

The red-seeded dandelion is probably common throughout eastern Canada, but has been seldom separated from Taraxacum Taraxacum. Our specimens are from Ottawa, Niagara Falls and Hamilton, Ont. 


\section{SOME NEW NORTHWESTERN COMPOSIT $Æ$.}

\section{By Edwd. L. Greene.}

Aster microlonchus. Stems about two feet high, very erect, divested of all lower leaves at flowering time, parted trom below the middle into numerous leafy and flowering branches forming a somewhat contracted and subpyramidal panicle; the reddened bark of stem and branches glabrous or obscurely pubescent : leaves of the panicle narrowly lance-linear, two inches long more or less, entire, sessile by a broad more or less perceptibly auricled base, thin, delicately scaberulous above, scabrous on the margin, glabrous beneath, marked by a delicate midnerve only, spreading or slightly deflexed : heads few and subracemose on the branches, or solitary at the ends of them, nearly an inch broad measuring the rays, the involucre short-campanulate, its bracts in about three series, narrowly spatulate-lanceolate, scaberulous, at least marginally, and spreading or recurved at tip : rays many and showy, apparently pale violet.

The types of this strikingly handsome new Aster are $\mathrm{Mr}$. Macoun's numbers 26,3 $\mathrm{S} 4$ and 26,385 from the Chilliwack Valley, B.C., collected 18 Aug., 190I. Its immediate allies are A. longifolius, Lam., A. hesperius, Gray, and A. ensatus, Greene. From all of these it differs not only in aspect, but in its foliage which, though sensibly roughened above, is yet of a texture so delicate that all the lower and properly cauline ones fade and fall before the time of flowering. It is perhaps more elegant and beautiful than any of its near relations, and rather smaller in stature, though growing in generous soil, and a climate abundantly moist and not severe.

Gnaphalium macounir. Apparently biennial, the stems rigidly erect, about two feet high, rather loosely leafy and clothed with a somewhat hirsute and viscid glandular-pubescence: leaves narrowly oblanceolate, acute, 3 inches long, the upper decurrent, all white-woolly beneath, light green and merely glandular-pubescent above: branches of the subpyramidal close panicle and the main stem for some distance below it densely white-woolly : involucres of middle size, their fearly scarious bracts all ovate, very acute : flower and fruit not seen. 
Collected in the Chilliwack Valley, B.C., 29 July, by Mr. Jas. M. Macoun, No. 26,847; also earlier at Revelstoke, No. 11,334, and again from the Warm Springs, Kootenay Lake, both in British Columbia, in the year 1890. No. 34,053 from Salmon Arm, J. R. Anderson, 1899 , is also the same. The species is related to $G$. decurrens, yet very distinct in habit and inflorescence, the dense white-woolly pubescence of the upper part of stems and branches of the panicle being very peculiar.

Gnaphalium proximum. Annual, erect, rather slender, a foot high, rather amply leafy, even up to the subsessile leafy-bracted clusters of heads : leaves thin, equally hoary on both faces, about I $1 / 2$ inches long, from ovate-lanceolate to oblong-lanceolate, broadest at the sessile and subcordate-clasping base, somewhat cuspidately acute: small plants simple and with but a terminal cyme ; larger ones with many short but strict branches, each with its cyme : bracts of the rather smallish involucres greenish-white, the outer broadly triangular lanceolate and acute, the inner very obtuse : pappus rather scanty, dull-white.

In moist ground in the vicinity of the Mammoth Hot Springs, Yellowstone Park, Messrs. A. and E. Nelson, 1899, distributed under No. 6,036 for G. Sprengelii, from which the species differs widely in habit, form of foliage, etc. .

Arnica levigata. Near $A$. latifolia and as large, the herbage of a deeper green and of much more thin and delicate texture: radical leaves from round-ovate and cordate to lanceovate and subcordate, 2 to 3 inches long, on slender petioles as long, the 2 or 3 cauline pairs broad and sessile, glabrous on both faces and coarsely, incisely, often doubly serrate-toothed, the larger 3 inches long and more than 2 in breadth: peduncles about 3, slender, puberulent under their narrowly turbinate involucres, the bracts of these uniserial, lanceolate, acuminate, scarcely pubescent excépt as to the villous-ciliolate margins; rays light-yellow, long and narrow; disk-corollas narrow-funnelform, the very short and hirtellous tube passing gradually into the limb, which much exceeds it in length: pappus white; achenes glabrous. 
By springs in woods of the Chilliwack Valley, B.C., 5 Aug., I90 I, J. M. Macoun, No. 26, 926. However much like $A$. Latifolia in general habit and leat-outline this may be, it must needs be distinguished specifically by its total lack of pubescence, thin texture, narrow involucres, funnelform corollas, etc. In true $A$. latifolia the bracts are glandular-hairy throughout, and not at all ciliate ; and its disk-corollas are much larger and not funnelform, the throat and limb swelling out abruptly from the short tube. Mr. Macoun writes that this species was collected in Igor on Mt. Cheam by Mr. J. R. Anderson and Dr. Jas. Fletcher.

Arnica aprica. Also akin to A. Latifolia and like it commonly more or less pubescent, but the hairs less rigid, and obviously jointed; the whole plant much smaller in all its parts, and the heads more numerous : radical leaves long-petioled and broadly or narrowly cordate-ovate, the cauline oval, sessile, all serrate or dentate, the teeth callous-tipped: bracts of turbinate involucre few, thin, oblanceolate, acute or acuminate, often purpletipped, nearly glabrous: rays few, rather deep-yellow, not deeply toothed, the teeth short and broad: disk-corollas with slender tube about as long as the subcylindric but abrupt limb: pappus firm, white; achenes long and slender, glabrous except a few obscure bristly very short hairs and as few minute glands about the summit.

This is represented by Mr. James Macoun's numbers 26,284 and 25,285 from the Chilliwack Valley. It is said to be a plant not of the woods, but of open ground along streamlets. It is readily distinguishable from $A$. latifolia not only by its smaller size and more numerous flowers, but by the character of its pubescence, and especially by its short merely tridentate rays; these last, in the real A. latifolia, being elongated, and very deeply cut at summit intu narrow almost ligulate teeth or segments.

Arnica Macounir, Greene, Pitt. iv., 16o. This species, hitherto known to me only from Vancouver Island, was copiously collected by Mr. James Macoun in the Chilliwack Valley, last season, the specimens bearing the numbers 26,927, 26,928 and 26,929 of the Geol. Surv. Herb. 
Arnica alraxtiaca, Greene, Torreya $i, 42$, founded on a plant of Oregon collected only by Mr. Cusick until now, must be credited to British Columbia, Mr. Macoun's No. 26,934 from the Chilliwack region matching perfectly the originals of the species.

Arsica confinis. Less than a foot high, monocephalous, or else with also a pair of monocephalous peduncles from the axils of the uppermost pair of leaves, these surpassing the terminal one ; herbage of a light green, viscid-puberulent as to the foliage, the stem with a sparse hairiness : lowest leaves obovate to oblanceolate, an inch long or more and petiolate, the cauline in about three pairs, ovate to lanceolate, I to 2 inches long, callous-denticulate, or serrate-dentate, or even subentire, acutish : heads of middle size, the involucral bracts biserial, acuminate, sparsely hirsute: rays deep-yellow, not large; disk-corollas with hirsute tube and naked limb about equal; achenes with a few hirsute hairs; pappus tawny, subplumose.

Chilliwack Valley, B.C., Mr. Macoun, No. 26,933. In characters of pubescence, flower and fruit this approaches A. ovala, Greene, but in toliage and habit it differs widely.

ARniza ASPERA. Stems clustered, often 2 feet high, equably leafy to the corymbose summit, loosely hirsute, more strongly and quite retrorsely so toward the base: leaves about 2 inches long, ovate-lanceolate, sessile by a broad base, the upper longer, the lower shorter than the internodes, rough-hairy on both faces, saliently callous dentate : peduncles several, slender; involucres small for the plant, campanulate, their bracts uniserial, hispidulous with pustulate hairs ; rays very obtuse and only minutely tridentate; disk-corollas with very short tube and rather longer limb about equally and very sparsely setose-hairy: achenes setosehairy; pappus tawny, subplumose.

The type of this species is a plant found by myself on Mt. Rainier, 19 Aug., 1889 , and then supposed to be $A$. amplexicaulis, which I have now for some time known to be a very different plant. A. aspera has also been collected by Mr. Piper at Snoqualmie Falls, Washington, and again in the Olympic Mountains. Mr. M. W. Gorman obtained it in 1897 among his plants of the Washington Forest Reserve. 
Arnica cana is a name needed to replace that of $A$. incana, Greene, Pitt., iv, 169; there being an Arnica incana of Persoon of much earlier date.

Arnica Crocina, Greene, Torreya, i. 42, first published in Pittonia, iv, 159 , by the untenable name of $A$. crocea, is now in hand from two additional stations. It is Mr. James Macoun's No. 26,93 r from dry slopes north of. Chilliwack Lake, 26th July, I9or ; also No. 34,074 of the Canad. Geol. Surv., collected by J. R. Anderson, I90I, from Mt. Cheam, north of Chilliwack River, B.C. 


\section{.}



[Reprinted without change in paging from THE OTTAWA NATCRALIST, Journal of the Ottawa Field-Natiralists Clti, Vol. XVI, (1903) Published at Ottawa. Canada. Price $S_{1.00}$ per year, to foreign countries \$1.25.] Issued February and.

\section{CONTRIBUTIONS TO CANADIAN BOTANY.}

BY

JAMES M. MACoun. 



\section{CONTRIBUTIONS TO CANADIAN BOTANY.1}

By JAmes M. MAcoun, Assistant Naturalist, Geological Survey of Canada.

$$
\text { XVI. }
$$

Anemone riparia, Fernald.

In maple woods, Tilsonburg, Ont. 1901. No. 33,561'; at Nepean Point, Ottawa, Ont., and Aylmer, Que., June, 1932. (John Macoun.) First Ontario records.

Ranunculus intertextis, Greene, Ott. Nat., vol. xvi, p. 33.

A common Rocky Mountain species until recently referred to $R$. natans.

Ranchculus hiRtipes, Greene, Ott. Nat., vol. xvi, p. 32.

Near Sandwich, Ont., 5th June, 1901. No. 33,582. (John Macoun.) The type station.

Ranuncluls cardiopetalus, Greene, Ott. Nat., vol. xvi, p. 32 .

At the Whirlpool Rapids, Niagara, Ont., 21 st May, I901. No. 33,581. (John Macoun) The type station.

Érysimum orientale, R. Br.

Greenwood, B.C. (Miss Mary L. Wilson.) Not recorded from British Columbia.

Sophia intermedia, Rydb.

Sandy soil at the end of Pelee Point, Lake Erie, rgor. No. 33,8:7. (John Macoun.) Eastern limit. ${ }^{3}$

1 Published by permission of the Acting Director of the Geological Survey of Canada.

2 These numbers are those under which specimens have been distributed from the Herbarium of the Geological Survey of Canadi.

3 The Geological limits given in these papers refer to Canada only. 
Draba verna, L.

Along the railway at St. David's, Niagara, Ont., 190r. No. $33,83^{2}$. (Macoun.) New to Ontario.

Camelina microcarpa, Andrz.

Of much the same range in Canada as $C$. sativa, from which it is separated by its shorter and generally smaller pods. C. microcarpa is pubescent, at least below, while C. sativa is glabrous or nearly so.

Smelowsikia calycina, C. A. Meyer.

Mt. Cheam, north of Chilliwack River, B.C., alt. $7000 \mathrm{ft}$. (J. R. Anderson, Dr. Jas. Fletcher, J. M. Macoun.) Not recorded west of Rocky Mountains south of Alaska.

LUNARIA ANNUA, L.

On "the island" (1891) and at Queen Victoria Park, Niagara Falls, Ont, 1901. (John Macoun.)

Vrola sagittata, Ait.

Abundant in woods at Sandwich, Ont, 1901. No. 33,915. (John Macoun.) The only Canadian pecimens we have seen, all the others so named proving to be $V$. dentata. See note in Part XIII of these contributions.

Stellaria graminea, L.

On an island in the Chilliwack River, B.C., 1901. ( $J$. M. Macoun.) Not before recorded from the west

Stellaria neglecta, Whe.

In woods at Queenston Heights, Ont. No. 34,055 (John Macoun.) Not recorded from Ontario.

Althate roseus, Cav.

Very abundant and well established along ruadsides near Niagara and at Tilsonburg, Ont., 1901. (John Macoun.)

Malva Alcea, L.

Roadside between Southampton and Owen Sound, Ont., rgor (John Macoun.) Probably common in Ontario but confounded with $M$. moschata. 
LINUM MEDITM, L.

Queenston Heights, Ont., 1901. (John Macoun.)

Oxalis cymosa, Smail.

At Amherstburgh and Windsor, Ont., rgor. (/ohn Macoun.) Recorded from Ontario in Britton's Manual.

ILEX Bronxensis, Britton.

I. verticellata var. tenuifolia, Torr.; Macoun Cat. Can. Plants, vol. 11, p. 3'5.

London, Ont. (Thos. Burgess.) Sandwich, Ont., 1890; Beech Ridge, 4 miles east of Leamington, Ont., rgor. No. 34, 128. (John Macoun.)

Ceanothus ovatus, Desf., vat. plbescens, T. \& G.

Pelee Point, Lake Erie. (John Macoun.) Very common around Sarnia and Point Edward, Lake Huron, where it has been collected by J. Dearness, 1889 ; C. K. Dodge, 1894 ; and Prof. Macoun, rgor. The ferrugineus pubescence of the leaf veins very conspicuous, especially in mature specimens, is omitted from the description in Britton's Manual. Probably a good species.

Parthinocissus quinguefolia, (L.) Planch, var. Laciniata, Planch.

In thickets at Winnipeg and Morden, Man. (John Macoun.) All western references to Ampelopsis quinquetolia are probably this species.

Meibomia sessilifolia, -(Torr.) Kuntze.

In woods at Sandwich, Ont., 1901. No 34,204. (John Macoun.) New to Canada.

ERvum Lens, L.

Fruiting in the Grand Trunk Railway yard at Niagara Falls, Ont., 1901. (John Macoun.)

Rubus Pacificus.

R. nizales, How ell, Flora N. W. America, p. 184 .

This plant was collected by Mr. W. B. Anderson at Comox, Vancouver Island, in 1899. The description in Hooker's Flora can not possibly apply to the species described in Howell's Flora, and the name Rubus Pacificus is 
proposed as a substitute. Again collected in rgor in the same place by Dr. James Fletcher and J. R. Anderson.

Potentilla pumila, Poir.

Sandy woods, Tilsonburg, Ont. No. 34,428. (John Macoun.) New to Canada.

Malus Rivularis, Røem.

From Sumas Lake up the Chilliwack Valley to the east end of Chilliwack Lake. Nos. 34,368-72. 190 I. (J. M. Macoun.) Eastern limit.

Pyrus communis, L.

Common in thickets and woods around Queenston Heights and Niagara, Ont., 1901. (John Macoun.)

Sorbus occidentalis, Greene.

A common species on the mountains bordering the Chilliwack Valley, east to the Skagit Range. Generally at between 5,000 and 6,000 feet altitude, but found as low as 3,500 and as high as 6,500 . - Its favorite habitat is on the tops of ridges, and it was lound in no other situation in $190 \mathrm{I}$ no matter what the altitude. (J.M. Macoun.) New to Canada.

Crateggus Douglasir, Lindl.

Along the Abitibi River between the oullet of Lake Abitibi and the mouth of Black River, N. E. Ontario in 1901, and in 1902 at Birch Bark Portage, about 100 miles below Black River. (W.J. Wilson.) Eastern limit.

Cratagus occidentalis, Britt,

The common Cratagus in the province of Assiniboia. Our specimens are from Wood Mountain, Old Wives' Creek, Medicine Hat and Milk River.

SAXIFRAGA HYPNOIDES, L.

S. caspitosa, Macoun, Cat. Can. Plants, vol. I, p. 150 in part.

Rocky cliffs along the sea-shore above Albour Brook, between the Madeline River and St. Anne des Monts, Gaspé, Que., 1882. (Macoun.) New to America. 
Saxifraga Tolmat, T. \& G.

The range of this species in Canada is extended by the following references: Mountain summits opposite Vancouver, B.C. (T. Henry.) North of Chilliwack River, south slope of Cheam Range, B.C. alt. 7,000 feet. No. 34,948; Tami Hy Mountain, Chilliwack Valley, B.C. No. 34,949. (J. M. Macoun.)

Hemieva violacea, Wheelock.

Near Kaslo, B.C., 1901. (Miss Ethel Blackman.) New to Canada.

Mitella Trifida, Graham.

Alpine slopes, Mount Arrowsmith, Vancouver Island, 1887. (John Macoun.) Same locality, 19u1. (J. $R$ Anderson and Dr. James Fletcher.) Common between 4,500 and $5, j 00$ feet altitude in the Chilliwack Valley, B.C. Nos. 34,864 and 34,865 . (J.M. Macoun.)

Mitelia Breweri, Gray .

Mountains at Chilliwack Lake, B.C. Nn. 34,866 . ( / M. Macoun.) Western limit.

Mitella ovalis, Greene.

Damp places, Goldstream, Vancouver Island, I887. No. 8,497. (John Mucoun.) Our only Canadian specimen.

Mitella Caulescens, Nutt.

A common plant in woods throughout the Chilliwack Valley, B.C. Nos. $34,860,34,86$ I and 34,863 . ( J. $M$. Macoun.) Our first Canadian specimens.

Mitella Pentandra, Hook.

Alpine woods, Mt. Arrowsmith, Vancouver Island, 1887. (John Macoun.) Same locality, rgor. (J.R. Anderson and Dr. James Fletcher.)

Onagra Oakesiana, Britton.

Gaspé, Gulf of St. Lawrence ; near London, Ont.; Port Colborne, Ont., No. 44.465; Southampton, Ont., No. 44464 (John Macoun.) Seldom separ ted from O. biennis. 
Epilobium luteum, Pursh.

Collected by Cowley in the Cariboo District, B.C.. in 1870 but not recorded. This was the first time it was collected in Canada. Common on mountains in the Chilliwack Valley, B.C. (J.M. Macoun.)

Tillaka Valllanti, Willd.

Tracadie Beach, Prince Edward Island, 1901. (J.R. Churchill.) Collected at Mt. Stewart, P.li.1., by Prof. Macoull in 1888 and recorded in Part v. of these papers as Tillaea simplex, Nutt.

Sedum frigidum, Rydb., Bull. Turr Bot. Club, vol. 28, p. 282.

All the western references to Sedum Rhodiola in Macoun's Catalogue of Canadian plants go here. Dr. Rydberg is hardly correct in describing this species as "an arctic-alpine" plant as it is abundantly repre-ented in our herbarium by specimens from near sea level in British Columbia and the warmer parts of Alaska.

Sambucus melanocarpa, A. Gray.

Crow Nest Pass, Rocky Mts. No. 20,59r. (John Macoun.) Eastern limit.

Eupatorium Rydbergit, Britt.

Near Brandon, Man. No. 13,9.34. (John Macoun.) Along ditches near Chilliwack, B.C. No. 86,486. (J.M. Macoun.) Not before recurded from Canida.

Aster polyphyllus, Willd.

On Birch Island, Lake Huron, Aug. 26th, 1901. No. 26,359. (John Macoun.) New to Canada. Determined by Mr. M. L. Fernald.

Erigeron Gormani, Greene.

Rocky ledges on Tami Hy Mountain, Chilliwack Valley, B.C. No. 26,46r. (J.M. Macoun) Not recorded south of Yukon, but it is probable that much of the Rocky Mountain plant referred to $E$ compositus var. glabratus is this species. 
Erigeron angustifolius, Heller.

An abundant species on rocky banks of rivulets running into Chilliwack Lake, B.C., always at between 2,500 and 3.500 feet altitude. No. 26,468. (J. M. Mucoun.)

Galinsoga parviflora, Cav.

Roadsides in the northern part of London, Ont., I902.

(J. Dearness.) New to Canada.

Artemisia Suksdorfi, Piper, Bull. Turr. Bot. Club, vol. 28, p. 42.

A. vulgaris var. Californica, Macoun, Cat. Can. Plants, vol. I, p. 258 , and No. $x$ of these contributions, p. 275 .

A coast species but collected on a gravel bar 12 miles up the Chilliwack Valley, B.C., in 1901 by J. M. Macoun. This point is between 40 and 50 miles from the coast.

Arnica lanceolata, Nutt.

A. Chamissonis, Macoun, Cat. Can. Plants, vol. I, p. 26r in part.

From New Brunswick, (Fowler, Hay, Wetmore), and Quebec, (Macoun) to Lake Superior, (Dr. R. Bell)

Araica Columbiana, Greene, Pittonia, vol. iv, p. 160.

Maclennan River, Lat. $33^{\circ}$, B.C., July 27 th, 1898 . No. 19.646. ( $W$. Spreadborough.) Among the many specimens of Amica in our herbarium we find none but Spreadborough's to be this species.

Arnica Macolnir, Greene, Pittonia, vol. iv, p. I6o.

The type of this species was collected by Prof. John Macoun at Comox, Vancouver Island, July Ist, I893. It is represented in our herbarium by specimens collected by Prof. Macoun at Chinaman's Creek, Alberni Canal, Vancouver Island, August 4th, 1887. The type is in Dr. Greene's herbarium.

Arnica lonchophylla, Greene, Pittonia, vol. iv, p. I64.

Athabasca River, Lat. $53^{\circ} 30^{\prime}$, Alta. June $25^{\text {th, }} 1898$.

No. 19,647. (W. Spreadborough.)

Arnica subcordata, Greene, Pittonia, vol. iv, p. 173.

Athabasca River and Pembina River, Alta. No. 19,644 (W. Spreadborough.) 
Senecio pseudoaureus, Rydb.

In a marsh, east of Chilliwack Lake, B.C. No. 16,682. (J.M.Macoun.)

Senecio Idahoensis, Rydb.

Shady banks, mouth of Silese Creek, Chilliwack River, B.C. No. 26,685, (J. M. Macoun.)

Silphium Terebinthinaceum, L.

The reference in Pdrt $\mathrm{XV}$ of these contributions should have been credited to J. Dearness instead of to C. K. Dodge.

Agroserus Greenir, (A. Gr.). Rydb.

On snow slides, Chilliwack Lake. B.C. No. 26,810. ( $J$. M. Macoun.)

Gaylussacia frondosa, T. \& G.

Edmonton, Ont. (Jas. While), Lincoln Co., Ont. (W. C. McCalla.) Sarnia, Ont., No. 54, 163. (John Macoun.) Not before recorded from Canada. Confounded with $G$. resinosa.

Cassiope stelleriana, DC.

Near the summit of Mt. Cheam, north of Chilliwack River, B.C. No. 54, i6o. (J M. Macoun.) Recorded from but one other locality in British Columbia.

Pterospora Andromeda, Nutt.

One specimen of this widely distributed but very lucal species was collected near the Chilliwack River, B. C., in I90 I by J. M. Macoun.

Allotropa virgata, T. \& G.

Very abundant in deep woods at Chilliwack Lake, B.C., at between 3,000 and 4,000 feet altitude. No. $54,149$. ( $/ . M$. Macoun.) Our first specimens from the B. C. mainland.

IIypopitys fimbriata, (Gray.)

Woods at about 1,500 ft. altitude, Chilliwack River, B.C. No. 54,173. (/. M. Macoun.) Recorded in Canada from Vancouver Island only. 
Primlla Americana, Rydb., Bull. Torr. Bot. Club, vol. 28, p. joo, $P$. farinosa is apparently confined to northeast America if it occurs on this continent at all. All the western references to $P$. farinosa in previous Canadian publications should be placed here.

VINCA MINOR, L.

Roadsides at "the whirlpool," Niagara, Ont. (John Macoun.)

Phlox paniculata, L.

Railway emhankment near Chatham, Ont. (John .Macoun.)

Well naturalized. Not recorded from Canada.

Hydrophllcm occidentale, Gr, var. Fendleri, Gr.

In woods near Chilliwack Lake, at $4,000 \mathrm{ft}$. altitude. No. 54.325. (/. M. Macoun.)

Nemophila pustulata, Eastivood, Bull. Torr. Bot. Club, vol. 28, p. 145 .

Described from specimens collected by Prot. John Macoun near Victoria, Vancouver Island, and distributed as $N$. parviflora Dougl. under the number 667. This is an abundant species near Victoria and has been distributed from the herbarium of the Geological Survey under the numbers $666,667,16,250$ and $16,248$.

Onosmodium Viroinianum, DC.

The specimens credited to Ontario in Macoun's catalogue of Canadian Plants, vol. I, p. 343 prove to be $O$. Carolinianum. We have no authentic record of $O$. Virginuanum being found in Canada.

ECHINOSPERMUM DEFLEXUM, Lehm.

Mr. M. L. Fernald writes that the only American specimens of true $E$. deflexum in the Gray herbarium are one from Wisconsin, and one collected in waste places at Cambellton, N.B., July 29 th, 1876 , by R. Chalmers. It was probably introluced from Europe in both places.

Castillieia oriopala, Greenman.

Mountain slopes, alt. 6,000 tt., south of Tulameen River, B.C., 1888, (Dr. G. M. Dareson.) Mount Cheam, Lower 
Fraser River, B.C., $1898,($ J.R. Anderson.) At an altitude of between $5,5^{\circ 0}$ and $6,000 \mathrm{ft}$. on nearly all mountains north and south of Chilliwack River, B.C. Nos. 54,434, 54,435, 54,4.36. Growing generally with Parnassia fimbriata and Leptarrhena pyrolafolia. When growing the flowe.s are bright plum color shading to pink and creamy white. (J.M. Macoun.)

Castilleia rupicola, Fernald.

First collected in Canada, by Dr. James Fletcher and Mr. J. R. Anderson on Mt. Cheam, Lower Fraser Valley, B.C. Not rare, generally on inaccessable cliffs, both north and south of the Chilliwack River. Nos. $54,437,54,4+1$ and 54,438. (J.M. Macoun.)

Castilleia Angustifolia, Don. vat. Bradburit, Fernald.

Confounded with $C$. miniata in our herbarium. Parson's Farm and other places near Victoria, Vancouver Island, No. 714 ; Nanaimo, Vancouver Island, No. 715; Deer Park, Columbia River, B.C., No. 17,277 (Macoun.) Thompson River, B.C. $(A . J$. Hill.) North Arm, Burrard Inlet, B.C.; on gravel bars, Chilliwack River, B.C., No. 54,439; north of Chilliwack Lake, B.C., No. 54,440. (J. M. Macoun.)

Dasystoma flava, Wood.

In woods at Queenston Heights, Ont. This species seems to be confined to the Niagara region where it has been found by several collectors in recent years.

Anychia Canadensis, (L.) B. S. P.

Amherstburgh, Ont., 1901. (John Macoun.) The specimens referred to $A$. dichotoma in Part $\mathrm{x}$ of these contributions are this species.

Salix Prinoides, Pursh.

Below Brock's monument, Queenston Heights, Niagara, Ont., :9or. (John Macoun.) New to Canada.

Arceuthobium pusillum, Peck.

On Picea nigra, in a bog at Tracadie Beach, Prince Edward Island, July $3 \mathrm{Ist}, 190 \mathrm{I}$. (J.R. Churchili.) Also collected on P. E. I. by Mr. L. W. Watson. 


\section{CyPRIPEdium candidum, Willd.}

Abuut three miles from Port Elgin, Ont. (A.R. Innis.) Dr. James Fletcher found large numbers of this plant growing on hummocks on a damp prairie lour miles south of Brandon, Man., in the beginning or July, 1899 . Mr. Norman Criddle also collected the same plant at Aweme, Man., near the Douglas swamp about 50 miles east of Brandon.

Smilax Rotundifolia, L.

Collected at Lake Annis and at Brazil, Yarmouth Co., N.S., in 1898 and again in 1902 by Mr. J. E. Barteaux. Not before recorded east of Ontario.

Streptopus BRevipes, Baker.

In deep hemlock woods, Chilliwack River, B.C. No. 34, iog. ( J. M. Macuun.) New to Canada.

Streptopl's clrvipes, Vail., Bull. Torr. Bot. Club, vol. 28, p. 267.

Apparently the commonest species in British Columbia. Easily separable from $S$. roseus by its simple habit and nongeniculate and much shorter peduncles. Our specimens are from Asulcan Glacier, Selkirk Mts, No. 27,646a; Revelstoke, B.C., No. 27,646. (John .llacoun.) Port Simpson, B.C. (Jas. McEvoy.) Cascades on Skagit River, B C. (Dr. G. M. Dawson.) Common in the Chiliwack Valley, B.C. (/. M. Macoun.) Specimens of simple habit but with the long geniculate peduncles of S. roseus were collected on Queest Creek, Shuswap Lake, B.C., by J. M. Macoun July 27 th, 1889.

Vagnera brachypetala, Rydb., Bull. Torr. Bot. Club, vol. 28, p. 268.

Described from specimens collected near the Asulcan Glacier in 1897 by Mrs. Cornelius Van Brunt. A common species in British Columbia, especially on Vancouver Island. Distinguished by its short petals and purple fruit.

Brontea lactea, Wat.

Rocky bank 5 miles from Chilliwack, B.C. No. 54.04I. I90I. (J.M Macoun.) 
Camassia Leichtlini, Wat.

Fields and meadows at Chilliwack, B.C. No. 54,06r. (J.M. Macoun.) Not recorded from mainland in B.C.

Lilium umbellatum, Pursh.

A common species from Winnipeg, Man., to the Rocky Mountains, seldom separated from L. Philadelphicum Collected by Prof. Macoun in rgor at Johnstone's Harbour, Lake Huron. No. 54,059 Eastern limit.

ERythrontum PRopullans, Gray.

This species is recorded in Part IV of Macoun's catalogue of Canadian Plants as having been tound in Elgin Co. No specimens were collected and later investigations have forced us to the conclusion that the plant noted was E. albidum.

Lloydia serotina, Reich.

Bare mountain tops, alt. 6,500 ft., Chilliwack Lake, B.C. No. 54,068, and at alt. 6,00o ft., Tami Hy. Mt., Chilliwaçk River, B.C. No. 54,070, 1901. (J. M. Macoun.) Not recorded from British Columbia.

Juncus Dudleyi, Weigand.

The greater number of our specimens under J. tenuis prove to be this species. It ranges from Ontario to B.C.

Scleria verticillata, Muhl.

Abundant on Toronto Island, Ont. No. 34,588 (John Macoun.) Known before only from Presq'ile Pt., Lake Ontario.

Scleria triglomerata, Michx.

Walpole Island, Lambton Co., Ont. (C. $K$. Dodge.) Sandwich, Ont. No. 34.590. (John Macoun.) Only other record, London, Ont.

Elecharis olivacea, Torr.

Near Galt, Ont. 1902. (W. Herriot.) Our only Canadian specimens.

Carex typhinoides, Schwein.

Collected in several localities in the vicinity of Ottawa, Ont., but always referred to $C$. squarrosa. Our specimens are 
from Hull, Que., Buckingham, Que.. and Duck Island near Ottawa.

Carex lupuliformis, Sartwell.

Near Galt, Ont. igo2. (W. Hernott.) New to Canada.

Setaria vertichlata, Beauv.

On Carlirg street, London, Ont., 1902. ( $J$. Dearness.) Other specimens in our herbarium which have been referred here prove to be not this species, which is probably not of so wide distribution in Canada as has been thought.

BROMUS ERECTUS, Huds.

Roadsides on the south side of and concession, London township, Middlesex Co., Ont., rgoz. ( $J$. Dearness.) New to Canada.

[Reprinted without change in paging from THE OTTAWA NATtrALIST, Journal of the Ottawa Freld-NAtiralists' CltB, Vol. XVI, (rgo3). Published at Ottawa, Canada. Price $\$ 1.00$ per year; to foreign countries $\$ 1.25$. Issued February 2nd. 





[Reprinted from ThE OtTawa Naturalist, Vol. XX, without change in paging. Published October I5th, 1906.]

\section{CONTRIBUTIONS TO CANADIAN BOTANY.*}

By James M. Macoun, Assistant Naturalist, Geological Survey of Canada. XVII.

Since the last of these papers was published a great many species have been added to the list of those known to occur in Canada ; the distribution of others has been greatly extended and a large number of notes worthy of publication have accumulated in our herbarium. Much of this material will be utilized in publications which will be issued from this Department at an early date but it is hoped to print from time to time in THE OTTAWA Naturalist records that might not find a place elsewhere. Some of these records have appeared in other publications, but as these notes are intended primarily for Canadian workers not all of whom have access to current botanical literature, and in nearly every case new information as to distribution has been added, it has seemed best to make the record as complete as possible by includ. ing some matter that has been published elsewhere.

Dicksonia PILosiuscula, Willd.

In sandy woods, Courtland, Norfolk Co., Ont., 1901. (John Macoun.) Rare in western Ontario.

Asplenium RUta-MURARIA, L.

On limestone rocks, north end of Manitoulin Island, Georgian Bay, Ont. Collected by Dr. Scott of Southampton, in 1901. New to Canada.

Adiantum pedatum, L., var. Aleuticum, Ruprecht.

A. pedatum, Cat. Can. PI., II : 263 in part.

Represented in our herbarium by four sheets of specimens, all collected on Mt. Albert in the Stickshocks, Gaspé, Que. Two of these sheets were collected by Prof. John Macoun in 1882, and two by Messrs. Collins and Fernald in

- 1905 .

* Published by permission of the Director of the Geological Survey of Canada. 
Equisetum laevigatum, Braun.

Roadsides at Windsor, Ont., 1902. No.66,396, (John Macoun.) Not recorded from eastern Canada.

Sparganium fluctuans, (Morong) Robinson, Rhodora. vil : 60. S. androcladum, var. fluctuans, Cat. Can. Pl., iI : 70.

The only Canadian locality cited by Dr. Robinson is Lake Memphremagog, Que. Our specimens are from Campbellton, N.B., No. 28,052*, (Chalmers), Lake Mistassini, Que., No. 28,053, (J.M. Macoun) and Great Opeongo Lake, Algonquin Park, Ont., No. 22,562. (John Macoun). It was reported by J. M. Macoun from Severn River, Keewatin.

Panicum Philadelphicum, Bernh.

$P$. capillare, L., var. flexile, Gattinger.

P. flexile, (Gatt.) Scribner.

On sand, southern point of Pelee Point, Lake Erie, Ont., July 28, 1892 . Referred at the time to $P$. capillare; by marshes, Sarnia, Ont., Herb. No. 26,332, and on Birch Island, Lake Huron, No. 26,331. (John Macoun.) Pelee Point, Lake Erie, Sept. 7 th, 1905, growing among Juniperus Virginiana. (A.B. Klugh.)

Trisetum melicoideumi, (Mx.) Vasey.

Graphephorum melicoides, Cat. Can, Plants 11 : 228 in part.

Woodstock, N.B., No. 22,687; Madeline River, Gaspé, Que., No. 29 48I. (John Macoun.) Aroostook River, N.B. (Williams, Collins and Fernald.) Ste. Anne des Monts River, Gaspé, Que. (O. D. Allen.)

Tristeum melicoideum, (Mx.) Vasey, var. Cooleyi, (Gr.)

Scribn., Rhodora, vill : 87.

Graphephorum melicoides, Cat. Can. Plants II : 228 in part.

Little Cascapedia River, Que. (Collins, Fernald and Pease.) River de Brig, Anticosti, Que., No. 29,479; Chelsea, Que., No. 6r, 297; Hastings Co., No. 29,482 ; Johnstone's Harbour, Lake Huron, Ont., No. 26,222. (John Macoun.) Galt, Ont. (W. Herriot.) Fishing Islands, Lake Huron, Ont. (J. Bell.)

*Specimens have been distributed from the herbarium of the Geological Survey under these numbers. 
Avena Striata, Michx. forma albicans, Fernald, Rhodora, vir: 244. A. striata, Cat. Can. Pl. II: 213 in part.

Distinguished from the species only by its pale, strawcolored glumes. Collected on Mount Albert, Gaspé, by John Macuun in 1882, No. 30,085. Described from specimens found at the same place and at Bic, Que., by Messrs. Fernald and Collins in 1904 and 1905 .

Bromus Japonicus, Thunb.

B. patulus, Mert. \& Koch.

Collectec at Toronto, Ont., by Mr. W. Scott and called $B$. squarrosus to which it is very similar. Mr. Scott's specimens differ from typical $B$. Japonicus in their short-rayed panicles. Introduced. New to Canada.

Scirpus validus, Vahl.

S. lacustris, Cat. Can. Pl., II : 99 in part.

Sable Island, N.S., 22,633. (Macoun.) Campbellton, N.B., 32,359. (R. Chalmers.) Ottawa, Ont., 7,54r; Chelsea, Que., 6r, I87; Niagara Falls, Ont., 34,583 ; Algonquin Park, Ont., 2 r,906; Lake Nipigon, Ont., 32,357. (Macoun.) Ed. monton, Unt., 25,344. (Jas. White.) Grassy Narrows, Lake Winnipeg, 32,356. (J. M. Macoun.) Brandon, Mau., 16,407; Sage Creek, Sask., 16,410 ; Cardston, Alta., 68,933 ; Cypress Hills, Alta., 16,409. (Macoun.) An abundant and widely distributed species not represented in our herbarium from west of Alberta.

Scirpus occidentalis, (Watson) Chase, Rhodora, vi : 68 .

S. lacustris, Cat. Can. Pl. II : 99 in part.

S. lacustris, var. occidentalis, Wat, Cat. Can. PI. II : 100.

Brackley Point, P.E. I., 32,360 ; Annapolis, N.S., 32,358; Grand Narrows, Cape Breton Island, N.S., 20,772; Sarnia, Ont., 34,582. (Macoun.) Toronto; Ont. (W. Scott.) Skull Creek, Crane Lake, Sask., 7,540; Prince Albert, Sask., 16,408; South Saskatchewan River, 32,361; Kananaskis, Rocky Mountains, 32,362. (Macoun.) Canoe River, head of Columbia River, Rocky Mts., 20,773. (IV. Spreadborough.) Widely distributed in British Columbia but seldom collected. 
S. occidentalis is distinguished from $S$. validus by achenes $1 / 3$ larger, by scales $1 / 4-1 / 3$ longer than the achene and nearly twice as long as the scales of $S$. validus, viscid-pubescent, overlapping $/ / 2$ their length or more; by the cylindric more densely fruited spikelets in capitate clusters; and by the denser umbels and harder culms.

Scirpus heterochetus, Chase, Rhodora, vi : 70.

Distinguished from $S$. validus and $S$. occidentalis by the 3 -cleft style, by the triquetrous achene, by the fragile bristles, fewer and shorter. An apparently rare species in the United States and not yet recorded from Canada. Mr. Ezra Brainerd found the three species growing in Lake Champlain where $S$. occidentalis begins to ripen seeds about six weeks later than $S$. validus; $S$. heterochatus flowers there at a date midway between the two.

Rhynchospora capillacea, Torr, var. leviseta, Hill.

In bogs at Southampton, Ont,, Aug. 2oth, 1901, No. 34,573. (John Macoun.) Wet sand !along the shore of Lake Huron at Oliphant, Ont. (A.B. Klugh.)

Carex Katahdinensis, Fernald, Rhodora, il : I 7 I.

Collected by Prof. Ezra Brainerd at the "Grand Discharge" of Lake St. John, Que., Aug., I9or.

Juncus Bufonius, L. var. Halophilus, Buch. \& Fernald,

Rhodora, VI : 39 .

Mr. Fernald records this variety from Riviere du Loup, Que., New Carlisle, Que., Bonaventure River, Que., and from Tracadie Beach and beach near Summerside, Prince Edward Island. Our only herbarium specimens are from Grand Narrows, Cape Breton Island, N.S., 20,708, (John Macoun), and mouth of Dartmouth River, Gaspé Co., Que. (Collins, Fernald and Pease.)

Allium recurvatum, Rydb.

Confounded with $A$. cernuum of the east. Differs from $A$. cernuum in the leaves, the more slender, ridged scape, the larger involucre and the more distinct midveins of the 
perianth segments. In $A$. cermuum the leaves are almost flat and more or less keeled. In $A$. recurvatum there is no keel and the channel is rounded as well as the back. The leaves of $A$. cernuum are also much wider, the flowers are generally much paler in that species and the perianth segments have an indistinct midvein. A. recurvatum is common in the Rocky Mountains and British Columbia.

Habenaria macrophylla, Goldie.

This species is much rarer than $H$. orbiculata with which in recent years it has been confounded. H. orbiculata ranges from the Atlantic to the Pacific and north to Alaska. $H$. macrophylla has not been found west of Wisconsin. Our specimens are from Newfoundland, 13.771, (B. L. Robinson \& H. Schrenk), and Muskoka, Ont., 27,223. (W. Spreadborough.) Many specimens of both species have been examined by Mr. Oakes Ames; the spur of $H$. orbiculata was found to be from 16 to $27 \mathrm{~mm}$. long, while that of $H$. macrophylla ranged from 32 to $43 \mathrm{~mm}$. in length. The flowers of the latter species are also much larger.

Salix chlorolepis, Fernald, Rhodora, vil : 186.

Meadows at the headwaters of Ruisseau au Diable, Mt. Albert, Gaspé, Que. (Collins and Fernald.)

Salix macrostachya, Nutt.

Along the Kettle River at Cascade, B.C. In flower, June 26th, 1902, No.68, 128. (J.M. Macoun). New to Canada.

Salix serissima, (Bailey) Fernald, Rhodora, vi : 6.

S. lucida, Cat. Can. PI. II : $45^{\circ}$ in part.

Mr. Fernald gives no other Canadian localities for this species than "north shore of Lake Superior." Our herbarium specimens are from the mouth of Albany River, James Bay, Hudson Bay,"No. 62,628. ( $W$. Spreadborough) ; Salt Lake, Anticosti, Que., No. 24,584. (John Maconn); Galt, Ont., No. 63,120. (W. Herriot); Nipigon, Lake Superior, Ont., No. 24.583. (John Macoun) ; Severn River, Keewatin, No. 2,028, Beren's River, Man., No. 24,618, and Muskeg Island, Lak- 
Winnipeg, Man, No. 24,619. (Jas. M. Macoun); Grattan Creek west of Battle River, Alta.; Edmonton, Alta., No. 24,62I, and Bow River at Morley, Alta., No. 24.620. (John Macoun).

Salix Lucida, Mahl., var. intonsa, Fernald, Rhodora, vi : II.

Recorded by Mr. Fernald from St. John Rivar and tributaries, Maine, Quebec, and New Brunswick. Our specimens are from Montmorency Falls, Que., Nos. 68,782 and 68,783. (John Macoun.)

Salix lucida, Muhl, var. angustifolia, Anderson.

Grand Lake, N.B., No. 24,586. (John Britlain); bank of Exploit River, Newfoundland, No. 13,674. (Robinson \& Schenk.)

Humulus Japonicus, Sieb. \& Zucc.

In waste places at Wakefield, Que., 1903. (John Macoun.) Naturalized.

Comandra Richardiana, Fernald, Rhodora, vil : 32 .

C. umbellata, Nutt., in part.

So far as shown by our specimens $C$. umbellata does not occur in Canada, everything so called being the recently dessribed $C$. Richardsiana.

Polygonum nuttallit, Small.

$P$. intermedium, Macoun, Cat. Can. Plants, II : $35^{2}$.

Grassy banks, Middle Creek, Chilliwack River. B.C., No. 54,740. (J.M. Macoun.) Not recorded from mainland of B.C.

Polygonum punctatum, Ell., var. Leptostachyon, (Meisn.) Small.

Low ground near Sumas Lake, B.C. No. 54,752. (J. M. Macoun.) New to Canada. Abundant, but perhaps introduced.

Polygonum bistortoides, Pursh.

A common species at an altitude of between 5,000 and 6,000 feet on mountains in the Chilliwack and Skagit valleys, B.C., near the International Boundary. (J.M. Macoun.) 
Chenopodium Boscianum, Moq.

Sandy thickets, Pelee Point, Lake Erie. No. 54,724. (John Macoun.) New to Canada.

Aquilegia Columbiana, Rydb., Bull. Torr. Bot. Club, xxix : 145.

This species is somewhat intermediate between $A$. formosa and $A$. truncala and has been mistaken for both. It has the habit, spur and sepals of the former and the short truncate lamina of the latter. From Banff to Alaska.

Delphinium Brownir, Rydb., Bu.1 Torr. Bot. Club, xxix : 148.

This is most nearly related to $D$. glaucum but differs in the puberulent leaves with narrow segments, the lax raceme with more erect pedicels and the darker flowers. Described from specimens collected at Banff in 1893 by Addison Brown. A common plant in that region.

Ranunclits alleni, Robinson, Rlıodora, ViI : 220.

R. affinis var. leiocarpus, Cat. Can. Pl I : 18.

First collected by Mr. J. A. Allen on Mt. Albert, Gaspé, Que, in $188 \mathrm{r}$, the next year by John Macoun at the same place, No. $1,01_{5}$, and in 1883 on Table Top Mountain not far from Mt. Albert by James Perter, No. 68,678. Other localities cited by Dr. Robinson are: Okkak, Labrador, and Rama, Labrador.

Ranunculus glaberrimus, Hook.

Penticton, Lake Oranagan, B.C., April 12 th, 1903. No. 59,519. (W. Spreadborough.) Not recorded from that region. Ranunculus Yukonensis, Britt.

Near Peace River Landing, Atha., No. 59,521, June 8th, 1903. (J. M. Macoun.) Recorded before only from the Yukon district.

Caulophyllum thalictroides, Mx.

In woods along the Assiniboine River near Portage La Prairie, Man. In flower, May 3ist, 1906. (W. Herriot.) Western limit in Canada. 
Lepidium DRABA, L.

Waste places at Trail, Columbia River, B.C. No. 67,986. (J. M. Macoun.) Not recorded from B.C.

LePIdiUM SPINOSUM, L.

Near the "ball grounds," Toronto, Ont., 1904. ( $W$. Scott) New to Canada. A native of the Orient and of Greece.

Sisymbrium officinale, Scop.

Rare in Canada, our specimens being from Niagara, Ont., No. 33,859. (John Macoun) ; Wingham, Ont., No. 2, 1 10 (J.A. Morton), and Esquimauit, Vancouver Island, B C., No. 2, 109. (John Macoun). The inflorescence and pods, even at full maturity, subtomentulose.

Sisymbrium officinale, Scop. var. leiocarpum, DC.

This variety as pointed out by Dr. Robinson (Rhodora, vol. vII : 102) is the common form in North America being represented in our herbarium by specimens from Baddeck, Cape Breton Island, N.S., No. 18,039, (John Macoun); Ottawa, Ont., No. 2, I I3, (John Macoun); Wakefield, Que., Nr. 59,8I3. (John Macoun); Belleville, Ont, No. 2, I I 4, Uohn Macoun); Nelson. Kootenay Lake. B.C., No. 2, I I I, (John Macoun); Sicamous, B.C, No. 2, I I 2, (John Macoun); Nanaimo, Vancouver Island, B.C., No. 2,115, (John Macoun); Chilliwack River, B.C., No. 33,860 . (J.M. Macoun). The inflorescence nearly smooth; the pods entirely glabrous or with a few scattered hairs.

Radicula clavata, (Rydb.) Bull. Torr. Bot. Club., xxix: 235. Nasturtium palustre, DC. var., Macoun, Cat. Can. Plants, II : 3 oo in part.

Port Heney and Agassiz, B.C., 1889. (John Macoun.)

Dentaria tenella, Push.

Harrison, B.C., 1902. No. 63,504. (W. Spreadborough.) Eastern limit in Canada. 
Draba McCalle, Bull. Torr. Bot. Club, Xxix : 241.

Moose Mountain, Elbow River, Alta., No. 18,139, I897; Summit of Pipestone Pdss, Rocky Mt Park, No.64.412, 1904. (John Macoun.) Described from specimens collected by Mr. W. C. McCalla at Banff in 1899 . This species belongs to the $D$. incann group bat differs from that species in the elongated peduncle, long pedicels, short pubescent pod and large petals.

Arabis Collinsir, Fernald, Rhodora, vil : $3^{2}$.

“Q $\mathrm{Q}$ uickly distinguished from $A$. Holboellii by the loose hispidulous pubesence of the stem and pedicels, the smaller flowers and the very sle der acutish pods." Collected on dry limestone conglomerate ledges, headland in the harbour of Bic, Rimouski Co, Que, July i8, 1904 (J. F. Collins \& M. L. Fernald.)

Drosera rotundifolia, L. var. comosa, Fernald, Rhodora, vir:9.

A dwarf variety of the common sundew with crimson or roseate instead of white flowers; the petals are sometimes foliaceous and the carpels are developed in maturity into green, glandular broadly obovate or oblate petioled leaves. Collected in abundance near the mouth of Grand River, Gaspé Co., Quebec., in 1904 by Messrs. J. F. Collins, M. L. Fernald and A. A. Pease. An examination of a large series of specimens of $D$. rotundifolia in our herbarium shows nothing approaching this variety.

Saxifraga hieracifolia, Waldt. and Kit.

Pond's Inlet, Lat. $72^{\circ} 45^{\prime}$, Cockburn Island. Aug. 2oth, 1904. (Dr. L. E. Borden.) 





\section{CONTRIBUTIONS TO CANADIAN BOTANY, XVIII.}

Ex

J.1mes M. MACoun, Assistant Naturalist, Geological Survey of Canada.

[Reprinted from The OtTawa Natlralist, Vol. XX, No. 8, November, 1go6, Ottawa, Canada.] 

[Reprinted from THE OTTAWA: NATLRAList, Vol. XX, without change in paging. Published November 6th, 1906.]

\section{CONTRIBUTIONS TO CANADIAN BOTANY.*}

By James M. Macoun, Assistant Naturalist, Geological Survey of Canada. XVPII.

Mitella diversifolia, Greene.

Near Trail, Columbia River, B.C., May 19th, 1902. No. $64,574 . \dagger$ (W. Spreadborough.) New to Canada.

Heuchera flabellifolia, Rydb., N. A. Fl. xxiI : i I5.

H. parvifolia, Cat. Can. Plants I : $15^{8} \& 526$.

All the Canadian specimens referred to $H$. parvifolia in our herbarium prove to be $H$. flabellifolia. They are from Milk River Ridge, Alta. No. 10,560; Cypress Hills, Alta. No. 8,5I4, and Crow Nest Pass, Rocky Mts. No. 20,167. (John Macoun.) Milk River Ridge, Alta. No. 8,515. (Dr. G. M. Daveson.)

Heuchera Columbiana, Rydb., N. A. Fl. xxil : i 16.

H. cylindrica, var, alpina, Cat. Can, Plants, I : 526 in part. H. cylindrica, var. ovalifolia, Contr. Can. Bot. No. 6, p 5 , in part.

Crow Nest Pass, Rocky Mts. No. 8, 5oo. (Dr. G. M. Daruson.) Waterton Lake, Rrcky Mts. No. ro,561; Eagle Pass, C. P. Ry., B.C. No. 8,503. (John Macoun.) Trail, Columbia River, B.こ. No. 64.571. (J.M. Macoun.) Referred to $H$. glabella by Rosendahl, but apparently a good species.

Saxifraga Rufidula, (Small).

S. occidentalis, Cat. Can. Pl.. II : 32 I in part.

Micranthes rufidula, Small, N. A. Fl., xxII : 140.

Well characterized by the red-tomentose under-surface of the leaves. Described from specimens collected by Prof. John Macoun on Mount Finlayson, Vancouver Island, May

"Published by permission of the Director of the Geological Survey of Canada.

tSpecimens have been distributed from the herbarium of the Geological Survey under these numbers, 
17th, 1887. Collected July I7th, 1887, on Mount Arrowsmith, V.I., and May 19th, 1893, on Parson's Mountain near Victoria, V.I., by Prof. Macoun. The specimens collected in I 887 formed part of the material upon which Watson based his $S$, occidentalis.

Saxifraga lata, (Small.)

S. occidentalis, Cat. Can. Pl., II : $32 \mathrm{I}$ in part. Micranthes lata, Small, N. A. Fl., XxII : 145.

Described from specimens collected by Prof. John Macoun at Lytton, B.C., April 16th, 1890 . Not rare west of the coast range. $\ddagger$

Ribes oxycanthoides, L. var. Calciola, Fernald, Rhodora, viI: 155.

This variety resembles the species " but young branches, petioles and lower leaf surfaces permanently and densely whitetomentose." Collected or noted growing in calcareous soils in Bonaventure and Gaspé counties, Quebec, by Messrs. Collins, Fernald and Pease at the following places: Carlisle, Tracadigash Mt., mouth of Bonaventure River, New Richmond, Grand River, Percé, Little Cascapedia River and Dartmouth River. This variety was collected on "the island" Baddeck, Cape Breton Island, N.S., by Prof Macoun in 1898, Herb. No, 19,102. An intermediate form was collected on Cape Breton Island, the same same year at Grand Narrows, No. 19, 100, and Big Intervale, Margaree, No. 19, ror.

Crataegus Brunetiana, Sargent.

A common species about Quebec. Our specimens were collected in fruit near Quebec in 1902 by Dr. Robt. Bell,

SPIRAa sorrifolia, L.

Escaped from cultivation and well naturalized on the bank of the Gatineau River at the railway station, Wakefield, Que., 1903. (John Macoun.)

Geum pulrchum, Fernald, Rhodora, vit : I I.

Known in Canada only from specimens collected by Williams, Collins and Fernald, in boggy meadows by the St. 
Lawrence River at Bic, Quebec, but will probably be found elsewhere. Characterized by its "large, wide-spreading crimson calyx, deep claret-colored styles and the strongly contrasting broadly obcordate bright yellow petals"; suggesting Geum macrophyllum in the outline of the leaf only.

Medicago denticulata, Willd.

Toronto, Ont. ( $W$ Scolt.) Not recôrded from Ontario.

Vicia viliosa, L.

Camlachie, Ont, June I8th, 1901, No. 34,280. (John Macoun.) New to Canada, rare in North America. Introduced.

Geranium pratense, L.

Roadsides and pasture fiélds, Wakefield, Que., 1903. (John Macoun)

LiNUM CATHARTICUM, L.

On the left side of the entrance road, Beechwood Cemetery, Ottawa, Ont., 1903 (John Macoun.) Not before recorded from Ontario.

Empetrum nigrum, L., var. ANdinum, DC.

Distinguished from $E$. nigrum by its red fruit and tomentose or lanate young leaves. This plant was sent us irom Newfoundland many years ago and was named $E$. rubrum. Mr. L. Fernald has shown (Rhodora, vol. Iv : $147^{-1} 5^{I}$ ) that it is apparently identical with the Andes plant described by De Candolle.

Rhus Vernix, L.

$R$. venenata, Macoun, Cat. Can. Plants, 1 : 100 and 505 .

Abundant by the little lake west of East Templeman, Que., 1903. (John Macoun.) Not recorded east of S. W. Ontario.

IMPATIENS NOLI-ME-TANGERE, L.

On Kent street, Ottawa, Ont. Noticed there for several years previous to 1901 , when flowering specimens were collected in September. 
Malva Alcea, L.

Common by roadsides in Masham township near Wakefield, Que., 1903. (John Macoun.)

Anthriscus Cerefolium, Hoffm.

Roadsides at Cap à L‘Aigle, Que. No. 67,994. (John Macoun.) New to Canada.

Cicuta Douglasir, (DC.) C. \& R.

In marshes, Chilliwack Lake, R.C. No. 44,480 . (J. $M$ Macoun.) New to Canada.

Sanicula Nevadensis, Wats.

Revelstoke, B.C., I902. (W. Spreadborough.) Eastern limit in Canada.

Monotropa fimbriata, Gray.

In woods near Trout Lake, B.C. (E. Wilson.)

Gaultheria humifusa, (Graham) Rydberg.

C. Myrsmites, Hook.

Mountains at Lake Agnes, No. 66,473, and at Pipestone Creek, No. 66,474, Rocky Mountains, 1904. (John Macoun.) Not recorded from Rocky Mountains since Drummond's time.

Glaux maritima, L. var. obtusifolia, Fernald, Rhodora, IV: 2 i 5. G. maritima, Cat. Can. Pl. I: $3^{1} 5$ in part.

With the exception of a single specimen from Assinaboine Rapids, Man., (John Macoun), our herbarium specimens of this variety are from either the Pacific or Atlantic coasts. In the east it is represented in our herbarium by specimens from Brackley Point, Prince Edward Island, No. 15,982; Grand Narrows, Cape Breton Island, N.S., No. 19,849; Salmon River, Que., No. 68,641, and Murray River, Que., No. $68,64^{2}$ (John Macoun); Oak Island, Mahone Bay, N.S., No. 23,06o (Dr. C. A. Hamilton); Campbellton, N.B., No. ${ }_{5}, 986$ (Dr. R. Chalmers) ; Bathurst, N.B., No. 6o, 463 (Williams and Fernald); Cacouna, Temiscouata Co., Que., No. 67,057 (Collins and Fernald). From the Pacific coast, 
Chase River, Vancouver Isiand, No. 15.981; Comox, Vancouver Island, No. 635; Burrard Inlet, B.C., No. 15.979 (Uohn Macoun); Lacomb Island, Portland Canal, B.C., No. I 1,978 ( $/ . M c E v o y)$ : Renfrew District, Vancouver Island, No. 4I,4I3 (Rosendahl and Brand).

Dodecatheon puberllum, (Nutt.) Piper.

Grassy slopes, Penticton, Lake Okanagan, B.C. No. 61,247. (W. Spreadborough.) Damp spots at Trail, Columbia River, B.C. No. 66,531; west of Sophie Mt., B C. No. 66,532. U. M. Maconn.)

Crnanchum Vincitoxicum, R. Br.

Escaped from cultivation at Niagara Falls, Ont., 1904. ( $W$. Scott.)

Nemophila BReViflora, Gray.

Very abundant on damp grassy slopes at an altitude of 5,000 feet, Sophie Mt., S.W. of Rossland, B.C. No. 66,6 i 4 . U.M. Macoun.) New to Canada.

Polemonium elegans, Greene, Pittonia. III : 305.

P. confertum, Cat. Can. PI., II : 330 .

Summit of South Kootenay Pass, Rocky Mountains. No. 16,221. (Dr. G. M. Dawson.) Summit of Sheep Mountain, Waterton Lake, Rocky Mountains. No. 1 1,807. (John Macoun.) Second summit west of Skagit River, near the International Boundary. Alt. $7,000 \mathrm{ft}$. No. $68,716 . \quad(/ . M$. Macoun.)

Cynoglossum boreale, Fernald, Rhodora, vil : 249.

C. Virginicum, Cat. Can. PI. I: 335 and 567.

C. occidentale, Cat. Can. Pl. 1 : 567 , and II : 344 .

This species is not uncommon in Ontario and eastward throughout the Maritime Provinces, but west of Lake Superior it is very rare. In our herbarium we have no specimens from the wooded country north of the prairie region, where it was collected by Drummond, nor have we any specimens from the Rocky Mountains. Our herbarium material from British Columbia is represented by specimens from Donald in the Columbia valley and from Vernon near Lake Okanagan. 
Asperugo procumbens, L.

Waste places at Banff, Alta., 1903. (N. B. Sanson.) Not recorded west of Ontario.

VERBENA BRACTEOSA $\mathrm{x}$ STRICTA.

A Verbena, evidently a hybid between $V$. bracteosa and $V$. stricta was found growing very abundantly on dry sandy ground near Pt. Edward, Ont, Aug. 20, 1903. (C.K. Dodge.) Mertensia oblongifolia, Don.

Common on hillsides around Trail, Columbia River, B.C. Nos. 66,567 and 66,568 . (J.M. Macoun.) New to Canada.

Mertensia ciliata, Don.

South fork of Salmon River, near Idaho boundary. No. 66,566. 1902. (W. Spreadborough.) New to Canada.

Teucrium littorale, Bicknell.

Along the shore below Mahone Bay, N S. (Dr. C. A. Hamilton.) New to Canada.

Scutellaria nervosa, Pursh.

Dry open woods, Cedar Creek, Arner, near Kingsville, Ont. No. 54,679. (John Macoun.) New to Canada.

Mentha ARvensis, L. var. Lanata, Piper, Bull. Torr. Bot. Club, Xxix : 223.

Size and habit of var. Canadensis, Briquet (M. Can. adensis, L.) but the calyx, stem, petioles and often the whole underside of the leaf-blade densely lanate-pubescent.

Dry bed of torrent, Middle Creek, Chilliwack River, B.C. No. 54,657 ; bank of Chilliwack River, B.C. No. 54,656. ( J. M. Macoun.) New to Canada.

Solanum C:arolinense, L.

Very abundant at Point Edward, Lake Huron. No. 54,531. (John Macoun.)

Physalis pruinosa, L.

Streets of Southampton, Ont, No. 54,524. Uohn Macoun.) New to Canada. 
VERBASCUM LychNitis, L. Macoun.)

Roadsides at Sandwich, Ont. No. 54,5ro. (John

Chanorrhinum minus. ( $\mathrm{L}_{0}$ ) Lange.

Linaria minor, Desf.; Macoun, Cat. Can. Plants, 1 : 353.

Contr. to Can. Bot. Pt. xIr.

Kincardine, Ont. (W. Scott.) Point Edward. No. 54,467 , and Sarnia, Ont. No. 54,466; along the railway at East Templeman, Que., 1903. (John Macoun.)

Penstemon pulchellus, Greene.

Rocky summits, alt. 6,00o ft., Tami Hy Mountain, Chilliwack Valley, B. C. IgoI. (Jas. M. Macoun.) New to Canada. Probably not a good species but only a form of P. procerus.

Penstemon Digitalis, (Sweet) Nutt.

Another locality for this species is Farm Point. four niles from Cascade, Que. It is not easy to account for the occurrence of this plant as though generally treated as a garden escape it is found where there is no record of its having been cultivated.

Castalleja suksdorfir, Gray.

Abundant on sub-alpine slopes between the Chilliwack River and Mount Cheam, B.C., alt. 4,000 ft. Nos 54,442 and 54,443. (J.M. Macoun.) Not recorded from Canada.

Plantago aristata, Michx.

Galt, Ont. (W. Herriot.) Roadsides near Windsor, Ont. No. 54,70I. (John Macoun.) Introduced from the west, now well established.

Plantago media, L.

Roadsides under the shade of the maples along the Whortley Road, near London, Ont. (J. Dearness.) Of very rare occurrence in Canada. 
Galium bifolium, Wats.

Abundant on clay banks along the Dewdney Trail, west of Sophie Mt., B.C. Alt. 5,000 ft. No. 64,89o. (J. $M$. Macoun) New to Canada.

Anaphalis margaritacea. B. \& H. var. occidentalis, Greene.

Characterized by its bright green leaves, glabrous above. Confined in Canada, apparently, to the vicinity of the Atlantic and Pacific coasts where it is rare. We have no specimens from the interior.

Xanthium glabratum, (DC.) Britton.

In ditches by rcadsides and along streams near Sarnia, Ont. (C. K. Dodge.) New to Canada. Mr. Dodge has aiso collected X. Pennsylvanicum at Port Huron, Mich., just opposite Sarnia.

Xanthium Canadense, Mill.

Typical specimens of $X$. Canadense were collected by Prof. Macoun by the mill at Blue-berry Point, near Aylmer, Que., in 1903. During the same summer he collected $X$. echinatum, Murr., at Wakefield, and $X$. Pennsylvanicum, Wall. near St. Patrick's Bridge, Ottawa.

Galinsoga parviflora, Cav.

Toronto, Ont, I904. (W. Scott.) First collected in Canada by J. Dearness iu north London, Ont. in 190 I and more recently in the southern part of that city.

Chrysanthemum Leucanthemum, $L$.

Typical $C$. Leucanthemum as represented in our herbarium seems to be confined to the Atlantic and Pacific coasts our only specimens being from Newfoundland, No. I0,955, (Robinson and Schrenk); Boylston, N.S., No. 22,83o, (Dr.C. A. Hamilton); Big Intervale, Margaree, Cape Breton Island, N.S., No. 19,672, (John Macoun); New Carlisle, Bonaventure Co., Que., No. 69,07 I, (Williams and Fernald); Montmorency Falls, Que., No. 68,327, (John Macoun) ; Cedar Hill, Vancouver Island, B C., No. 14,503, (John Macoun.) The var. 
subpinnatifidum, Fernald, Rhodora, $v$ : is abundantly represested in the herbarium of the Geological Survey by specimens from Labrador to British Columbia.

Artemisia BIENNis, Willd.

Near the muuth of Albany River, James Bay, I904. (IT. Spreadborough.) Probably introduced.

Arvica Gasprnsis, Fernald, Rhodora, viI : I $q 8$.

Described frcm specimens collected on ledges of a hill near Ste. Anne des Monts, Gaspé, in I831, by Mr. J. A. Allen. Arnica plantaginea, Pursh.

Described from specimens cullected in Labrador and recorded from several stations there. Re-described by $\mathrm{Mr}$. Fernald, Rhodora, viI : 247.

ARnicA SORNBorgeri, Fernald, Rhodera, VII : 147.

Bank of a mountain brook at Rama, Labrador. (J.D. Sornborger.)

CarduUs nutans, $L$.

In the pasture on the Pêche River above the schoolhouse at Wakefieli, Que, 1903. (John Macoun.) Not recorded west of the Maritime Pr.vinces.

Cirsicm ariense, Hoffin. var. setosum. Ledeb.

In a second-growth woods abuet 200 yards from the Grand Trunk Railway at Lachine, Que.. 1905. No. 67.797. (Dr. Robt. Campbell.)

Centaurea Jacea, L.

Wante places at Owen Sound, Ont., 190r. Herb. No. 26,445. (John Macoun.) New to Eastern Canada.

LEJNTODON HISPIDUS, $L$. to Canada.

Moist meadows, Galt, Ont., Igo2 ( $W$. Herriot.) New SONCHUS ARVENSIS, L.

Albany, lames Bay. 1904. (IV. Spreaiborough.) 
Lactuca PUlchella, DC.

Mouth of Albany River, James Bay, 1904. (W. Spreadborough.). Not recorded from that region.

Prenathes racemosa, Mx.

The Beacoll, mouth of Moose River, James Bay, Igo4. (W. Spreadborough) Not recorded from that region.

Agoseris altissima, Rydb.

Prairies near Old Wives' Lake, north of Peace River, Atha., 1903. No. 61,242. ( $J . M$. Macoun.) Known before only from type locality in Montana. 




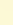









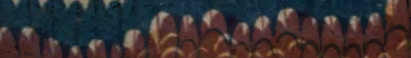

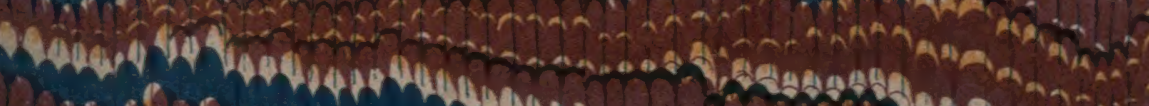

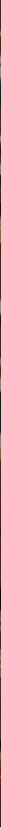

$\ln ^{2}$

and

\section{UN.VERSITY OF TORONTO LIBRARY}

Polpos

Antian

QK Macoun, James Melville

201 Contributions from the 201 Contributions from the Survey of Canada

BioMed

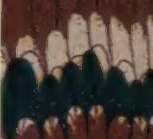

44444

Arome fot of की 4 (4) A $19 \log ^{2}$ Antist Natiat

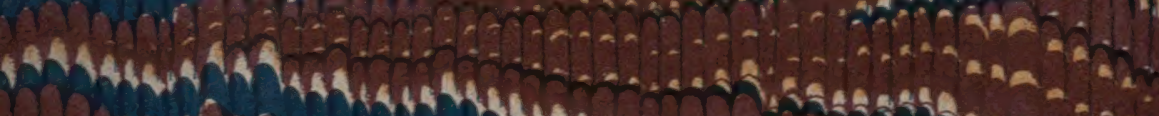
Fon 
